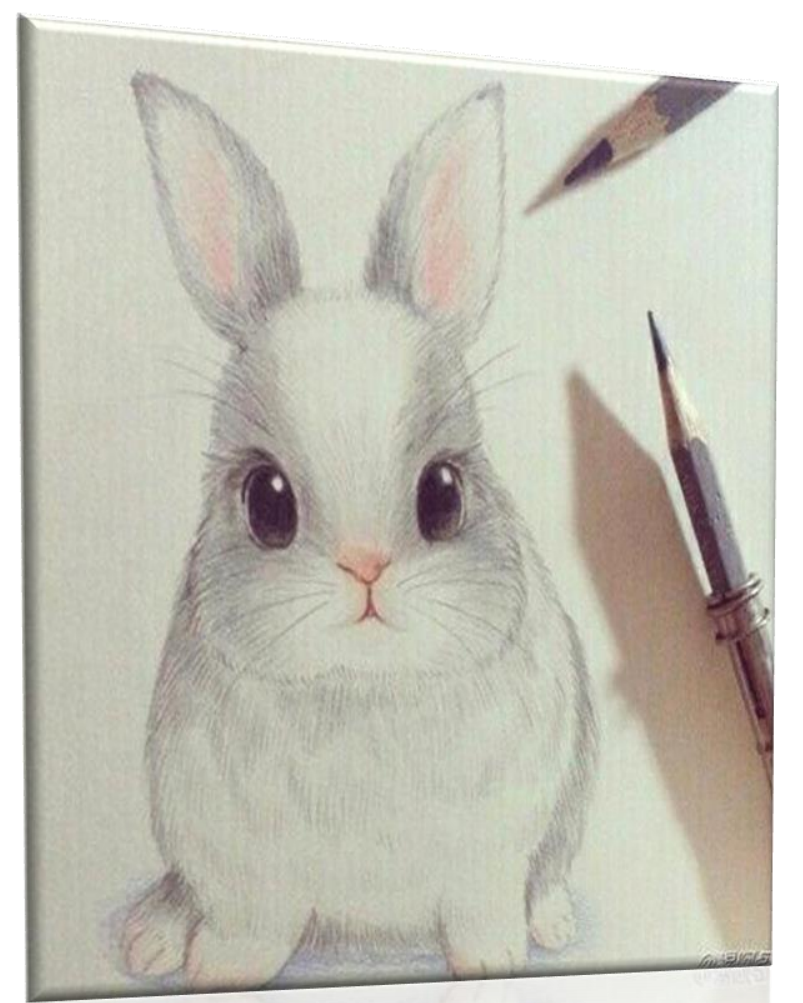

Supervisors:

Dr. Juan José Pascual Amorós Dr. Taha Najar

Ph.D. Thesis

JIHED ZEMZMI

Valencia, September 2020

IN VITRO AND IN VIVO CHARACTERIZATION OF GALACTOMANNAN EXTRACTED FROM FENUGREEK SEEDS (TRIGONELLA FOENUMGRAECUM) FOR YOUNG RABBIT NUTRITION
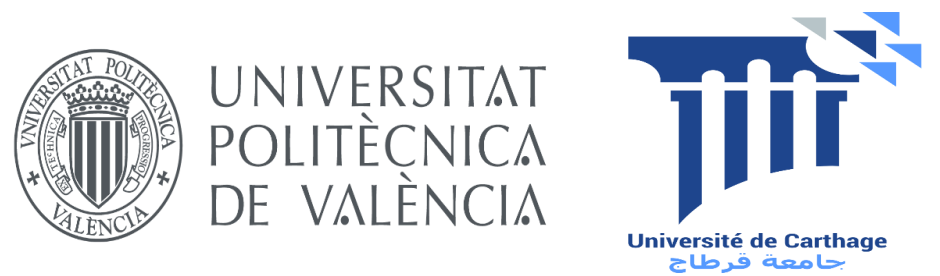



\section{IN VITRO AND IN VIVO CHARACTERIZATION OF GALACTOMANNAN EXTRACTED FROM FENUGREEK SEEDS (TRIGONELLA FOENUM-GRAECUM) FOR YOUNG RABBIT NUTRITION}

Ph.D. Thesis

JIHED ZEMZMI

Supervisors

Dr. Juan José Pascual Amorós

Dr. Taha Najar

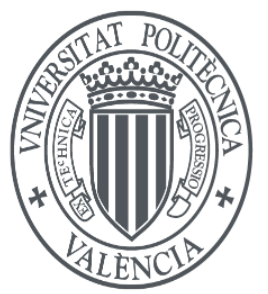

UNIVERSITAT POLITÈCNICA DE VALÈNCIA

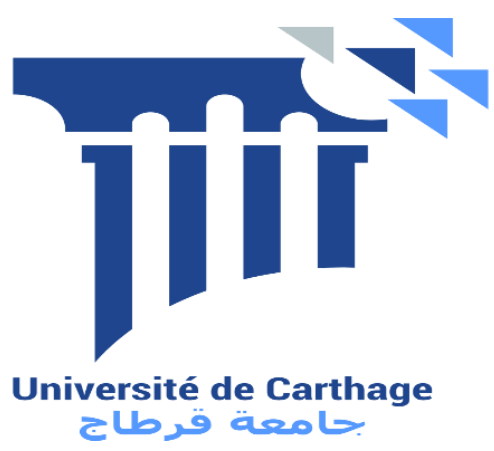

Departamento de Ciencia Animal ICTA National Agronomic Institue of Tunisia

September 2020 
Ask for knowledge from

the cradle to the grave 


\section{Acknowledgements}

Am grateful to a lot of people in my life and absolutely there is too much to say about them.

To my great loving parents Mohsen and Dalila thank you for giving me all, thank you for believing in me and being always sure that I can do big things in life.

To my little Zayneb, thank you for being the sweet laughter of our family and acting as the eldest overwhelming all of us even if you are the youngest.

To my brilliant Chayma, thank you for keeping surprising me showing strength, persistence and different ways of thinking.

To my dear brother Montassar, for taking care of my parents and being supportive to our family.

To Juanjo, thank you for being patient and kind, for responding every time I needed you, for showing me the best example of a great team leader and thesis supervisor, thank you for switching concepts in my head.

To Mr Taha thank you for providing huge quantities of ethanol to extract galactomannan, thank you for all the support and orientations you provided me.

No words will describe my gratefulness to Enrique so just thank you for being the best person and scientist, I ever met in my life till the moment, you made it very high for others to reach.

To Mr Abdouli thank you for preparing the base of this work, for teaching me the first steps of being a researcher.

To Luis thank you for making "galactomanano" possible hhh, thank you for making my thesis see the light even if you had never believed in prebiotics.

To Mari Carmen for supporting me and standing by my side every time I needed you, for being open and letting me in.

To Pablo and Paloma for their friendship, advices and orientations during those three years of the thesis.

To Eugenio thank you for carrying on the experiments in the farm and organizing it the best way you could.

To Pablo, Luis, Eugenio, Mari Carmen, Juanjo, Enrique and Juan Carlos, thank you for staying until 3 am in the farm during the sacrifice period.

To the brilliant engineers Mona and Balkis, thank you for making the work in Mateur possible, thank you for all the sacrifices you have made without complaining.

To Davi thanks for receiving me in your home for two weeks when you barely know me, thank you for all the help and the advices you gave me.

To my big friend Arturo Mark "chokran" for making me have family in Spain, for your delicious plates and for insisting whenever I feel ruined that the solution is in me.

Thanks and love to all my friends, Paloma, Aziza, Sawssen, Zahra, Rahma, Asma, Wafa, Ruthi, Daisy, Arturo, Olfa for all your support during those four years of my $\mathrm{PhD}$. 


\section{Abstract}

This thesis tackles the possible characterisation and utilisation of fenugreek (Trigonella foenum-graecum) seed gum (FSG) in the nutrition of young rabbits during the post-weaning period as an alternative to antimicrobials uses. The study was focussed on the behaviour of the extracted gum with different dietary fibre levels, both in vitro and in vivo.

In a first trial, starting from a basal commercial rabbit diet, three experimental diets were formulated with gradual levels of inclusion of FSG $(0,0.25,0.50 \%)$ given to three groups of rabbits starting from weaning at 31 days old to slaughter 94 days old. The effect of the experimental diets was studied on the faecal digestibility of the diet in two ages (38-41 days and 56-59days) and on the caecal fermentation parameters at the end of the experiment. On the other hand, starting from the same commercial rabbit diet five experimental diets were formulated containing $0,0.125,0.25,0.50$ and $100 \%$ of FSG that were submitted to in vitro incubation with rabbit caecal inoculum during $72 \mathrm{~h}$. Gas production and fermentation traits were measured. Apparent faecal digestibility and caecal fermentation parameters were not significantly affected by the in vivo inclusion of FSG up to $0.5 \%$. However, animals fed with FSG showed lower caecal $\mathrm{pH}$ values. Gradual dietary inclusion of FSG increased in vitro concentration of volatile fatty acids (VFA), while pure FSG increased the asymptotic gas production and the maximum substrate degradation rate and decreased the time after incubation at which half of the asymptotic amount of gas is formed. In vitro incubation of pure FSG decreased $\mathrm{pH}$ value, lactic acid concentration and $\mathrm{N}-\mathrm{NH}_{3}$ concentration and increased that of VFA.

In a second trial, FSG was characterised determining its chemical composition, galactose and mannose content and prebiotic potential. Pure FSG and gradual levels of FSG $(0,5,10,15$ and $20 \mathrm{~g} / \mathrm{kg})$, included both in diets rich in soluble fibre (SF) from beet pulp (included at 10\%) or in diets rich in insoluble fibre (IF) from 
defatted grape seeds (included at $10 \%$ ), were evaluated. They were submitted to enzymatic digestion with pepsin and pancreatin and then their indigestible fractions were submitted to fermentation using caecal inoculum. The indigestible fractions after enzymatic digestion were measured, as well as the nonfermentable fractions and the fermentation traits after incubation time (48 h). FSG was mostly composed of galactose and mannose $(630 \mathrm{~g} / \mathrm{kg})$ in 1:1 ratio and a moderate protein level (223 g/kg). Pure FSG was weakly affected by enzymatic digestion, only $145 \mathrm{~g} / \mathrm{kg}$ was dissolved. However, it was almost entirely disappeared $(984 \mathrm{~g} / \mathrm{kg}$ ) during the fermentation process. Consequently, FSG increased VFA concentration and decreased both $\mathrm{pH}$ value and $\mathrm{N}-\mathrm{NH}_{3}$ concentration. Th gradual inclusion of FSG in rabbit's diets affected some nutrients digestion such as the fibre fractions, starch and protein, besides to increase the fermentation fraction in SF diet but without any relevant effect on the fermentation profile.

In a last third trial, four diets were formulated according to $2 \times 2$ factorial design: a conventional rabbit diet (C), the same C diet supplemented by $10 \mathrm{~g} / \mathrm{kg}$ of FSG, a low-risk diet (LR), and the same LR diet supplemented by $10 \mathrm{~g} / \mathrm{kg}$ of FSG. C and LR diets differed in SF and crude protein levels (CP) (104 vs 205 and 156 vs $121 \mathrm{~g} / \mathrm{kg}$ of SF and CP respectively for C and LR diets). Two hundred and sixteen weaned rabbits (28 days of age) of the LP line were allocated in individual cages and divided randomly between the four treatments and allowed free access to feed and water. Mortality, morbidity, health risk index (HRi), daily feed intake (DFI), average daily gain (ADG) and feed conversion ratio (FCR) were controlled until 63 days of age. Coefficient of total tract apparent digestibility (CTTAD) of nutrients, on twelve rabbits per treatment, was determined from 49 to 53 days of age and finally, caecal environment was measured at 63 days of age. FSG dietary inclusion at $10 \mathrm{~g} / \mathrm{kg}$ did not affect performance or CTTAD of nutrients but did slightly increased neutral-detergent fibre (NDF) and acid-detergent fibre (ADF) 
digestibility in C diets. Similarly, caecal parameters were not affected by FSG except caproic acid concentration in C diets. Nevertheless, LR diets decreased mortality, HRi, DFI, ADG and CTTAD of organic matter and CP but increased FCR and CTTAD of NDF and ADF respect to $\mathrm{C}$ diets. Moreover, LR diets increased VFA concentration, the proportion of acetic, isobutyric and isovaleric while decreased the dry matter of the caecal content, N-NH3 and the proportion of butyric, caproic and valeric acids.

To summarise, FSG perfectly responds to the two first conditions to be prebiotic, being not digestible by gastrointestinal enzymes before the caecum and highly fermented once reached the caecum. It seems to affect selectively caecal microbiota due to its effect on VFA and $\mathrm{N}-\mathrm{NH}_{3}$ concentration besides to its effect on caproic and valeric proportions in conventional diets. FSG could increase viscosity of digesta limiting the solubilisation of some nutrients such starch and protein. FSG seems to be more effective in conventional commercial diets than in low-risk diets. Finally, it was confirmed that diets with high SF level and low CP could be a good tool against epizootic rabbit enteropathy (ERE) in a nomedicated breeding system at the cost of impaired growth parameters. 


\section{Resumen}

Esta tesis aborda la caracterización y posible utilización de la goma de alholva (Trigonella foenum-graecum) (FSG, por sus siglas en inglés) en la nutrición de gazapos durante el período posterior al destete como una alternativa al uso de antimicrobianos, centrándose en el comportamiento de la goma extraída con diferentes niveles de fibra dietaria, tanto in vitro como in vivo.

En el primer experimento, a partir de una dieta basal comercial de conejo, se formularon tres dietas experimentales con niveles graduales de inclusión de FSG $(0,0.25,0.50 \%)$ administrados a tres grupos de conejos desde el destete a los 31 días hasta el sacrificio a los 94 días. Se estudió el efecto de las dietas experimentales sobre la digestibilidad fecal en dos edades (38-41 días y 56-59 días), además de los parámetros de fermentación cecal al final del experimento. Por otro lado, a partir de la misma dieta comercial de conejo, se formularon cinco dietas experimentales que contenían 0.0 .125 , 0.25, 0.50 y 100\% de FSG, que se sometieron a incubación in vitro con inóculo cecal de conejo durante 72 h. Se midieron la producción de gas y las variables de fermentación. La digestibilidad fecal aparente y los parámetros de fermentación cecal no se vieron afectados significativamente por la inclusión in vivo de FSG hasta $0.5 \%$. Sin embargo, los animales alimentados con FSG mostraron valores de pH cecal más bajos. La inclusión gradual en la dieta de FSG aumentó la concentración in vitro de ácidos grasos volátiles (VFA, por sus siglas en inglés), mientras que el FSG puro aumentó la producción asintótica de gas y la tasa máxima de degradación del sustrato y disminuyó el tiempo de incubación en el que se forma la mitad de la cantidad asintótica de gas. La incubación in vitro de FSG puro disminuyó el valor del $\mathrm{pH}$, la concentración de ácido láctico y la concentración de N-NH3, y aumentó la de VFA.

En el segundo experimento, el FSG se caracterizó para determinar su composición química, su contenido de galactosa y manosa y su potencial como 
prebiótico. Se evaluaron tanto FSG puro como niveles graduales (0, 5, 10, 15 y 20 $\mathrm{g} / \mathrm{kg}$ ) incluidos en dietas ricas en fibra soluble (SF, por sus siglas en inglés) de pulpa de remolacha (incluida al 10\%) y dietas ricas en fibra insoluble (IF, por sus siglas en ingles) de semilla de uva desengrasada (incluida al 10\%). Se sometieron a digestión enzimática con pepsina y pancreatina y luego sus fracciones indigestibles se sometieron a fermentación usando inóculo cecal. Se midieron las fracciones no digestibles después de la digestión enzimática, así como las fracciones no fermentables y las variables de fermentación después del tiempo de incubación (48 h). La FSG se compone principalmente de galactosa y manosa (630 g/kg) en una proporción de 1: 1 y un nivel moderado de proteínas (223 g/kg). El FSG puro se vio poco afectado por la digestión enzimática, ya que solo se disolvieron $145 \mathrm{~g} / \mathrm{kg}$. Sin embargo, desapareció casi por completo (984 g/kg) durante el proceso de fermentación. En consecuencia, FSG aumentó la concentración de VFA, disminuyó el valor de $\mathrm{pH}$ y la concentración de $\mathrm{N}-\mathrm{NH}_{3}$. La inclusión gradual de FSG en las dietas de conejos afectó la digestión de algunos nutrientes, como las fracciones fibrosas, el almidón y las proteínas, además de aumentar la fracción fermentada en la dieta SF, pero sin ningún efecto relevante en el perfil de fermentación.

En el tercer experimento, se formularon cuatro dietas de acuerdo con un diseño factorial 2 x 2: una dieta convencional de conejo (C), la misma dieta C suplementada con $10 \mathrm{~g} / \mathrm{kg}$ de FSG, una dieta de bajo riesgo (LR, por sus siglas en inglés) y la misma dieta LR suplementada con $10 \mathrm{~g} / \mathrm{kg}$ de FSG. Las dietas C y LR se diferenciaban en el nivel de SF y proteína bruta $(\mathrm{CP}$, por sus siglas en inglés) (104 vs 205 y 156 vs 121 g/kg de SF y CP respectivamente para dietas C y LR). Doscientos dieciséis conejos de la línea LP se alojaron en jaulas individuales, se dividieron aleatoriamente entre los cuatro tratamientos y se les permitió el libre acceso al alimento y al agua. La mortalidad, la morbilidad, el índice de riesgo sanitario ( $\mathrm{HRi}$, por sus siglas en inglés), la ingestión diaria de pienso (DFI, 
por sus siglas en inglés), la ganancia media diaria (ADG, por sus siglas en inglés) y el índice de conversión alimenticia (FCR, por sus siglas en inglés) se controlaron hasta los 63 días de edad. El coeficiente de digestibilidad aparente total del tracto digestivo (CTTAD, por sus siglas en inglés) de los nutrientes se determinó en doce conejos por tratamiento, entre los 49 y 53 días de edad y finalmente se midió el ambiente cecal a los 63 días de edad. La inclusión de FSG en la dieta a $10 \mathrm{~g} / \mathrm{kg}$ de alimento no afectó al rendimiento durante el cebo ni al CTTAD de los nutrientes, pero aumentó ligeramente la digestibilidad de la fibra neutrodetergente (NDF, por sus siglas en inglés) y la fibra ácido-detergente (ADF, por sus siglas en inglés) en las dietas C. Del mismo modo, los parámetros cecales no se vieron afectados por la inclusión de FSG, excepto la concentración de ácido caproico en las dietas C. Sin embargo, las dietas LR disminuyeron la mortalidad, HRi, DFI, ADG y CTTAD de materia orgánica y CP pero aumentaron FCR y CTTAD de NDF y ADF con respecto a las dietas C. Además, las dietas LR aumentaron la concentración de VFA, la proporción de ácido acético, isobutírico e isovalérico mientras que disminuyeron la materia seca del contenido cecal, N$\mathrm{NH}_{3}$ y la proporción de ácidos butírico, caproico y valérico.

En resumen, la FSG responde perfectamente a las dos primeras condiciones para ser un prebiótico, ya que no es digestible por las enzimas gastrointestinales antes del ciego y es altamente fermentado una vez que alcanza el ciego. Parece afectar selectivamente a la microbiota cecal debido a su efecto sobre la concentración de VFA y N-NH , además de su efecto sobre la proporción de caproico y valérico en dietas convencionales. FSG podría aumentar la viscosidad de la digesta limitando la solubilización de algunos nutrientes como el almidón y la proteína. FSG parece ser más efectivo en dietas comerciales convencionales que en dietas de bajo riesgo. Finalmente, se confirmó que las dietas con alto nivel de SF y bajo de CP podrían ser una buena herramienta contra la enteropatía epizoótica del 
conejo (ERE, por sus siglas en inglés) en un sistema de producción no medicado, a costa de peores parámetros de crecimiento. 


\section{Resum}

Aquesta tesi aborda la caracterització i possible utilització de la goma de fenigrec (Trigonella foenum-graecum) (FSG, per les sigles en anglès) en la nutrició del conills durant el període posterior al deslletament com una alternativa a l'ús d'antimicrobians, centrant-se en el comportament de la goma extreta amb diferents nivells de fibra dietària, tant in vitro com in vivo.

En el primer experiment, a partir d'una dieta basal comercial de conill, es van formular tres dietes experimentals amb nivells graduals d'inclusió de FSG (0, $0.25,0.50 \%$ ) administrats a tres grups de conills des del deslletament als 31 dies fins al sacrifici als 94 dies. Es va estudiar l'efecte de les dietes experimentals sobre la digestibilitat fecal en dues edats (38-41 dies i 56-59 dies), a més dels paràmetres de fermentació cecal a la fi de l'experiment. D'altra banda, a partir de la mateixa dieta comercial de conill, es van formular cinq dietes experimentals que contenien $0.0 .125,0.25,0,50$ i $100 \%$ de FSG, que es van sotmetre a incubació in vitro amb inòcul cecal de conill durant $72 \mathrm{~h}$. Es van mesurar la producció de gas i les variables de fermentació. La digestibilitat fecal aparent i els paràmetres de fermentació cecal no es van veure afectats significativament per la inclusió in vivo de FSG fins a $0.5 \%$. No obstant això, els animals alimentats amb FSG van mostrar valors de pH cecal més baixos. La inclusió gradual en la dieta de FSG va augmentar la concentració in vitro d'àcids grassos volàtils (VFA, per les sigles en anglès), mentre que el FSG pur va augmentar la producció asimptòtica de gas i la taxa màxima de degradació del substrat i va disminuir el temps d'incubació en el qual es forma la meitat de la quantitat asimptòtica de gas. La incubació in vitro d'FSG pur va disminuir el valor del $\mathrm{pH}$, la concentració d'àcid làctic i la

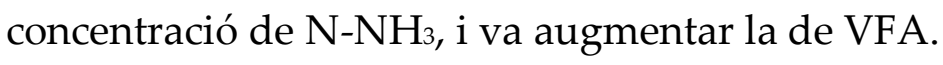

En el segon experiment, el FSG es va caracteritzar per determinar la seva composició química, el seu contingut de galactosa i manosa i el seu potencial com prebiòtic. Es van avaluar tant FSG pur com nivells graduals (0, 5, 10, 15 i 20 g/kg) 
inclosos en dietes riques en fibra soluble (SF, per les sigles en anglès) de polpa de remolatxa (inclosa al 10\%) i dietes riques en fibra insoluble (IF, per les sigles en anglès) de llavor de raïm desgreixada (inclosa al 10\%). Es van sotmetre a digestió enzimàtica amb pepsina i pancreatina i després les fraccions indigeribles es van sotmetre a fermentació usant inòcul cecal. Es van mesurar les fraccions no digestibles després de la digestió enzimàtica, així com les fraccions no fermentables i les variables de fermentació després del temps d'incubació (48h). La FSG es compon principalment de galactosa i manosa $(630 \mathrm{~g} / \mathrm{kg})$ en una proporció de 1: 1 i un nivell moderat de proteïnes (223 g/ $\mathrm{kg}$ ). El FSG pur es va veure poc afectat per la digestió enzimàtica, ja que només es van dissoldre 145 $\mathrm{g} / \mathrm{kg}$. No obstant això, va desaparèixer gairebé del tot $(984 \mathrm{~g} / \mathrm{kg})$ durant el procés de fermentació. En conseqüència, FSG va augmentar la concentració de VFA, va disminuir el valor de $\mathrm{pH}$ i la concentració de N-NH3. La inclusió gradual de FSG en les dietes de conills va afectar la digestió d'alguns nutrients, com les fraccions fibroses, el midó i les proteïnes, a més d'augmentar la fracció fermentada en la dieta SF, però sense cap efecte rellevant en el perfil de fermentació.

En el tercer experiment, es van formular quatre dietes d'acord amb un disseny factorial 2 x 2: una dieta convencional de conill (C), la mateixa dieta C suplementada amb $10 \mathrm{~g} / \mathrm{kg}$ de FSG, una dieta de baix risc (LR, per les sigles en anglès) i la mateixa dieta LR suplementada amb $10 \mathrm{~g} / \mathrm{kg}$ de FSG. Les dietes C i LR es diferenciaven en el nivell de SF i proteïna bruta (CP, per les sigles en anglès) (104 vs 205 i 156 vs 121 g/kg de SF i CP respectivament per a dietes C i LR). Doscents setze conills de la línia LP es van allotjar en gàbies individuals, es van dividir aleatòriament entre els quatre tractaments i se'ls va permetre el lliure accés a l'aliment i a l'aigua. La mortalitat, la morbiditat, l'índex de risc sanitari (HRi, per les sigles en anglès), la ingestió diària de pinso (DFI, per les sigles en anglès), el guany mitjá diari (ADG, per les sigles en anglès) i l'índex de conversió alimentària (FCR, per les sigles en anglès) es van controlar fins als 63 dies d'edat. 
El coeficient de digestibilitat aparent total del tracte digestiu (CTTAD, per les sigles en anglès) dels nutrients es va determinar en dotze conills per tractament, entre els 49 i 53 dies d'edat i finalment es va mesurar l'ambient cecal als 63 dies d'edat. La inclusió de FSG en la dieta a $10 \mathrm{~g} / \mathrm{kg}$ d'aliment no va afectar el rendiment durant l'engreix ni el CTTAD dels nutrients, però va augmentar lleugerament la digestibilitat de la fibra neutre-detergent (NDF, per les sigles en anglès) i la fibra àcid-detergent (ADF, per les sigles en anglès) en les dietes $C$. De la mateixa manera, els paràmetres cecals no es van veure afectats per la inclusió de FSG, excepte la concentració d'àcid caproic en les dietes C. No obstant això, les dietes LR van disminuir la mortalitat, HRi, DFI, ADG i CTTAD de matèria orgànica i CP però van augmentar FCR i CTTAD de NDF i ADF pel que fa a les dietes C. A més, les dietes LR van augmentar la concentració de VFA, la proporció d'àcid acètic, isobutíric i isovalèric mentre que van disminuir la matèria seca del contingut cecal, $\mathrm{N}-\mathrm{NH}_{3}$ i la proporció d'àcids butíric, caproic $\mathrm{i}$ valéric.

En resum, la FSG respon perfectament a les dues primeres condicions per ser un prebiòtic, ja que no és digestible pels enzims gastrointestinals abans del cec i és altament fermentat un cop que arriba al cec. Sembla afectar selectivament a la microbiota cecal pel seu efecte sobre la concentració de VFA i N-NH3, a més del seu efecte sobre la proporció de caproic i valéric en dietes convencionals. FSG podria augmentar la viscositat de la digesta limitant la solubilització d'alguns nutrients com el midó i la proteïna. FSG sembla ser més efectiu en dietes comercials convencionals que en dietes de baix risc. Finalment, es va confirmar que les dietes amb alt nivell de SF i baix de CP podrien ser una bona eina contra la enteropatia epizoòtica del conill (ERE, per les sigles en anglès) en un sistema de producció no medicat, a costa d'pitjors paràmetres de creixement. 


\section{Disclaimer}

Some results of this PhD Thesis are already published in peer review journals:

-Chapter I: Zemzmi J, Ródenas L, Blas E, Abdouli H, Najar T, Pascual J. J. 2020. Preliminary evaluation of fenugreek (Trigonella foenum-graecum) seed gum as a potential prebiotic for growing rabbits in Tunisia, effects on in vivo faecal digestibility and in vitro fermentation. World Rabbit Science. In press.

-Chapter II: Zemzmi J, Ródenas L, Blas E, Najar T, Pascual J. J. 2020. Characterisation and in vitro evaluation of fenugreek (Trigonella foenum-graecum) seed gum as a potential prebiotic in growing rabbit nutrition. Animals, 10(6), 1041.

Other results are in revision:

-Chapter III: Zemzmi J, Ródenas L, Blas E, Najar T, Pascual J. J. aaaa. Effect of fenugreek seed gum dietary supply in conventional rabbit diet and low digestive risk diet on in vivo performance, nutrient digestibility and caecal environment of growing rabbits. In revision. 


\section{Abbreviations}

ADF: acid detergent fibre

ADG: average daily gain

ADL: acid detergent lignin

AGP: antibiotic growth promoters

AOAC: Association of Official Analytical Chemists

C: conventional diet

CP: crude protein

CTTAD: coefficient of total tract apparent digestibility

TTAD: total tract apparent digestibility

DFI: daily feed intake

DM: dry matter

EE: ether extract

ERE: Epizootic Rabbit Enteropathy

FCR: feed conversion rate

FSG: fenugreek seed gum

IF: insoluble fibre

LR: low-risk diet

NDF: neutral detergent fibre

N-NH3: nitrogen ammonia

OM: organic matter

SF: soluble fibre

HRi: health risk index

TDF: total dietary fibre

VFA: volatile fatty acids 


\section{Index}

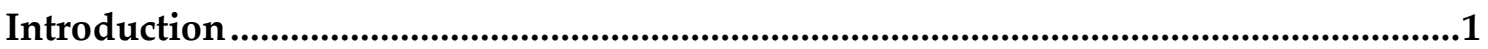

1. Do we have a sustainable meat rabbit industry? ...........................................................

2. Development of rabbit's digestive system ...................................................................

3. Dietary strategies targeting better digestive health in rabbits.........................................6

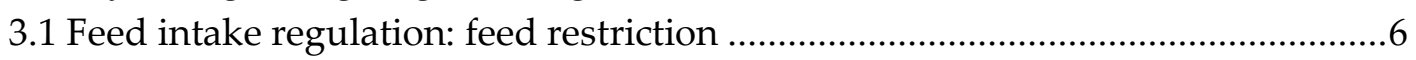

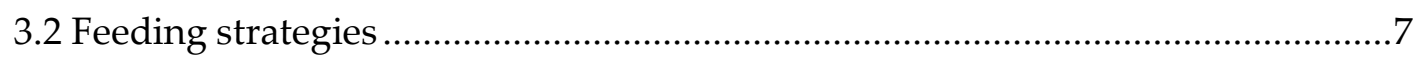

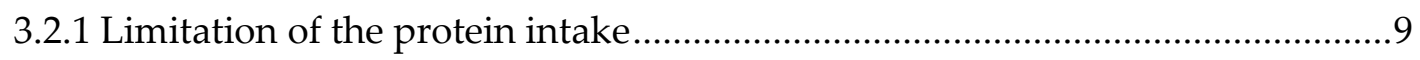

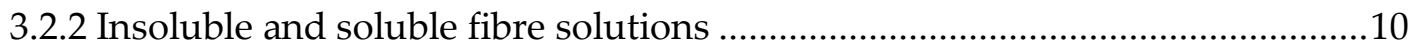

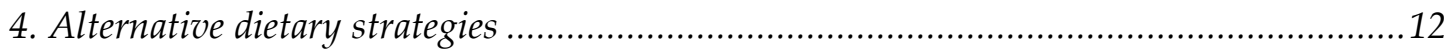

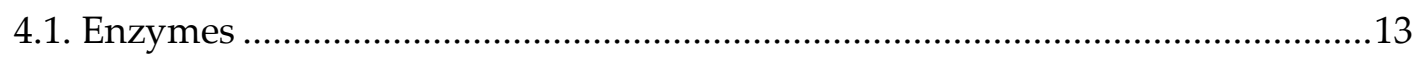

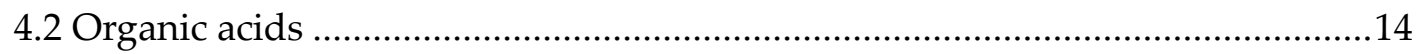

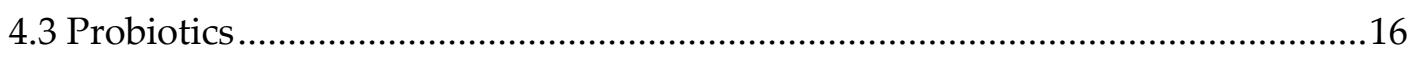

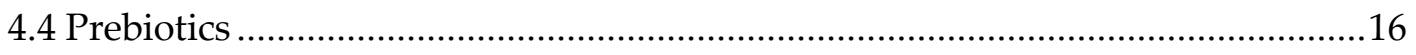

5. Fenugreek seed gum: Galactomannan ...................................................................... 19

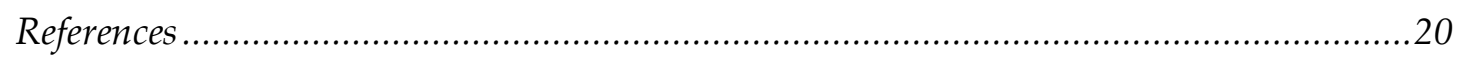

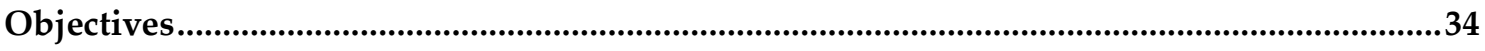

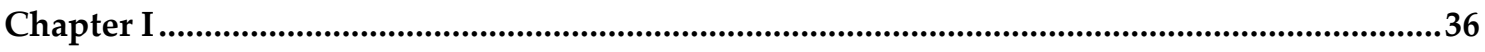

Preliminary evaluation of fenugreek (Trigonella foenum-graecum) seed gum as a potential prebiotic for growing rabbits in Tunisia: effects on in vivo faecal digestibility and in vitro

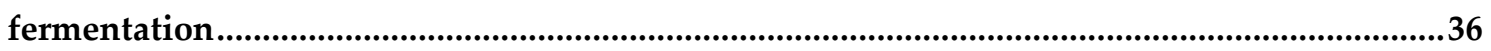

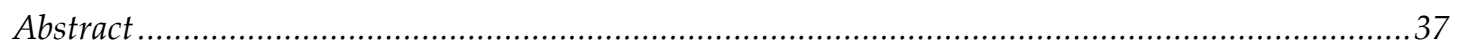

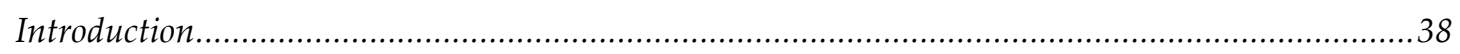

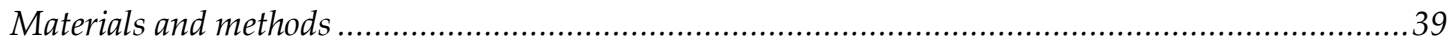

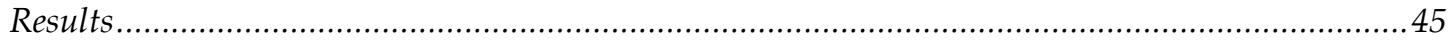

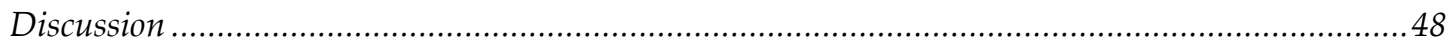

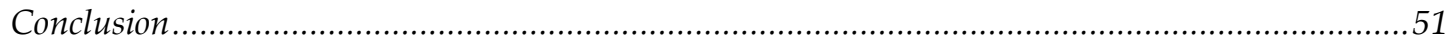

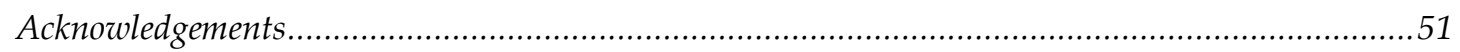

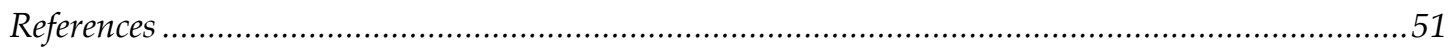

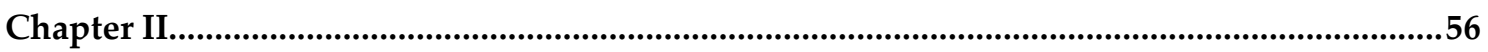

Characterisation and in vitro evaluation of fenugreek (Trigonella foenum-graecum) seed gum as a potential prebiotic in growing rabbit nutrition. .............................................................56

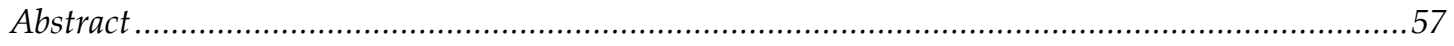

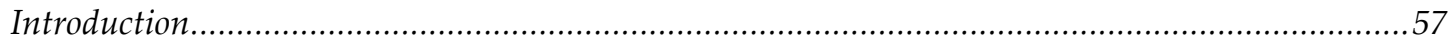




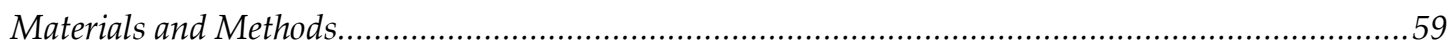

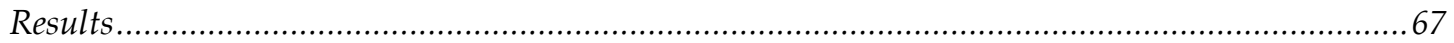

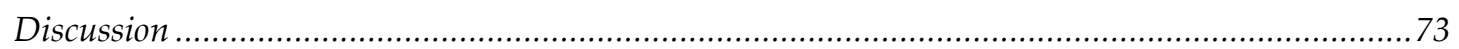

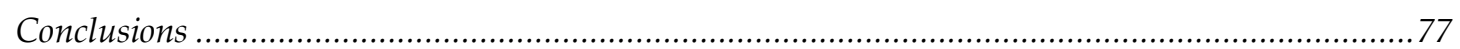

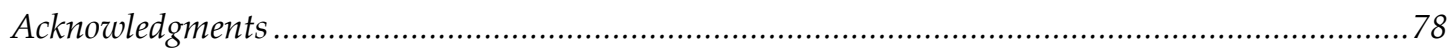

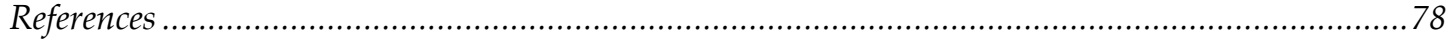

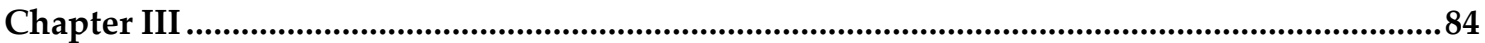

Effect of fenugreek seed gum dietary supply in conventional rabbit diet and low digestive risk diet on in vivo performance, nutrient digestibility and caecal environment of growing rabbits

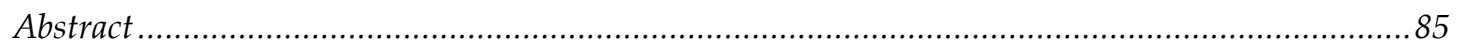

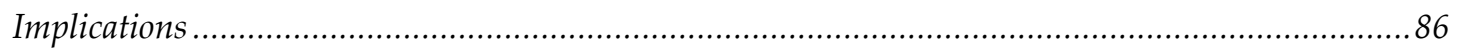

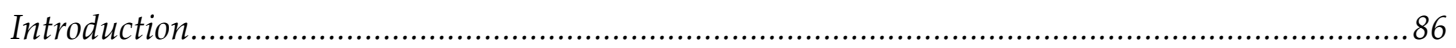

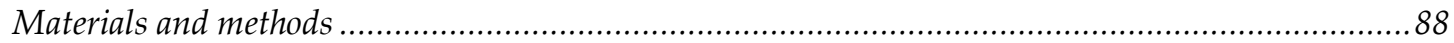

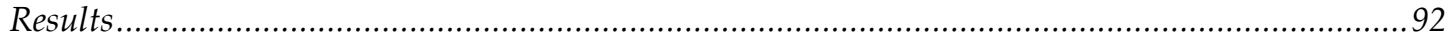

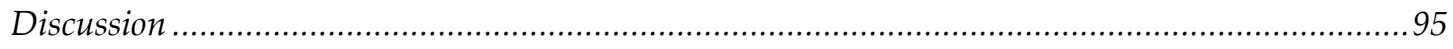

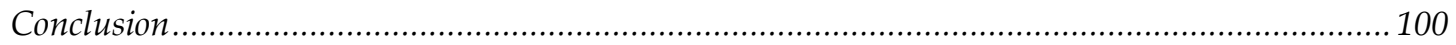

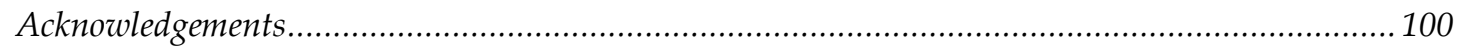

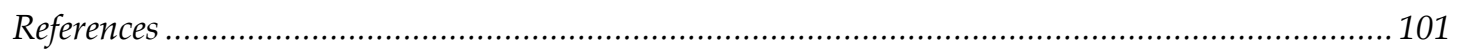

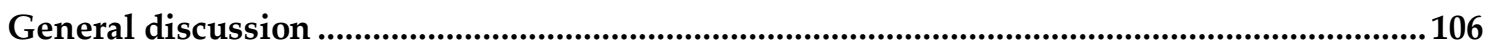

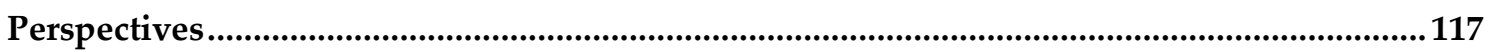

Dissemination of Results and Predoctoral Stay ................................................................119 


\section{List of Tables (short description)}

Table 1.1 Chemical composition of the experimental diets (Chapter I) ..........................40

Table 1.2. Feed intake and apparent faecal digestibility coefficients of nutrients. 45

Table 1.3. Caecal fermentation parameters of diets (Chapter I)..........................................46

Table 1.4. Gas production parameters and some in vitro traits of diets and FSG ............47

Table 2.1. Ingredients and chemical composition of the diets. (Chapter II).....................62

Table 2.2. Chemical composition of fenugreek gum. (Chapter II)....................................68

Table 2.3. Effect of urea on gas production kinetics of fenugreek seed gum...................69

Table 2.4. Pepsin and pancreatin digestion of the diets and FSG (Chapter II) ................69

Table 2.5. Caecal fermentation of the indigestible fractions of the diet and FSG ...........72

Table 3.1. Ingredients and chemical composition of the experimental diets...................91

Table 3.2. Mortality, morbidity rate and health risk index of the growing rabbits........93

Table 3.3. Nutrients digestibility of growing rabbits (Chapter III) .....................................93

Table 3.5. Caecal traits of growing rabbits at 63 day of age .............................................94 


\section{List of figures (Short description)}

Figure 1.1. Evolution of gas production during the in vitro incubation of FSG (Chapter I)

Figure 2.1. Digested fractions and fermented fractions of diets: SF, IF and FSG (Chapter II) . .70

Figure 2.2. Starch, crude protein and neutral detergent fibre content on the indigestibe fractions of diets (SF and IF) (Chapter II)..... .71

Figure 3.1. Growth performances of rabbits during the experimental time (Chapter III) 


\section{Introduction}




\section{Do we have a sustainable meat rabbit industry?}

Rabbit meat has a high nutritional value when compared to other meats eaten in Europe and North African countries, since it is high in protein and low in fat, calories and cholesterol (Combes and Dalle Zotte, 2005). Unfortunately, rabbit meat is barely consumed in Tunisia (300 g per capita en 2019, GIPAC) as a North African country example. Similarly, the consumption in Spain (940 g per capita en 2019; MAGRAMA, 2020) is 13 times lower than poultry meat consumption (12.6 kg per capita en 2018; Statista, 2020). This limited consumption is mainly due to cultural, sociological and economic reasons. In both societies, the inclusion of rabbit meat in daily feeding habits is not frequent, rather it is preserved for some typical dishes. Additionally, rabbit meat price is clearly high when compared to the meat of other species, mainly associated with greater handling fees, higher conversion rate, productive losses, price of their feed... which affects rabbit's meat production costs.

One of the major causes of mortality in rabbits and then economical losses in its meat industry is the Epizootic Rabbit Enteropathy (ERE) (Szalo et al., 2007). ERE could increase growing rabbits' mortality to $80 \%$ from the $6^{\text {th }}$ to $14^{\text {th }}$ week of age (Lebas and Coudert, 1997), and its causative agent remains unknown (Marlier et al., 2005). Therefore, the use of medication with antibiotics with veterinary prescription has been widely spread to help to control ERE and even other digestive diseases. Moreover, rabbits require high fibre diets, which are bulky and low in density unlike poultry and swine (Lukefahr, 2004). These requirements should be controlled in both quantity and quality to ensure digestive health. Gidenne (2015) proposed a minimum dietary level of lignocelluloses acid detergent fibre (ADF; 18\%) and lignins ( $>5 \%)$, balanced with an adequate quantity of digestible fibres ' $\mathrm{DgF}^{\prime}$ (ratio $\mathrm{DgF} / \mathrm{ADF}$ below 1.3). Although fibrous raw materials should have a lower price given their lower 
nutritional value, their inclusion often affects the price of feed as there is usually low real availability, they are bulky raw materials, which require processing for transport and utilization, and affecting granulation efficiency. Consequently, both medication and feeding costs make rabbit breeding more expensive for breeders, affecting the farm profitability and the price for rabbit's meat in our markets. "How to reduce medication" and "how to reduce production costs" are being the main challenges of research in the field of rabbit's nutrition for the two last decades. Countless researches have been done but we keep facing the same problems since the 90s which make the rabbit industry low sustainable (Rosell et al., 2009).

On the other hand, studying public consumption behaviour is essential to figure out other solutions for the sector. Consumer views, concerns and preferences must be taken into consideration concerning the implementation and monitoring of animal production systems, so that effective and acceptable regulations can be designed and enforced (Bennett et al., 2002). Some studies have demonstrated that some consumers are willing to pay for a range of products that exceed minimum welfare standards (Lagerkvist and Hess, 2011). Based on this previous statement, technical and commercial proposals of the rabbit industry might be focusing on animal welfare conditions and functional meat. From this point of view, the use of new feed additive ingredients that promote digestive health wellbeing, as probiotics, prebiotics, extracts with active principles..., seems to be welcome. Main of them are known even for human nutrition industry as promoters of the digestive and general wellbeing of the individual and could be an alternative to reduce the use of antibiotics, which are ethically and socially not accepted in our days.

\section{Development of rabbit's digestive system}

The digestive system of the rabbits has its own specificity making it different from other species such as pigs and poultry. The stomach, with a weak muscular 
layer, is the first compartment. It is always partially filled and acts as a storage cavity for feed and caecotrophes, with a $\mathrm{pH}$ ranging from 1 to 5 depending on the place of determination (Gómez-Conde et al., 2009). The stomach is connected to the small intestine ( $3 \mathrm{~m}$ long) where the secretion of bile, digestive enzymes and buffers occurs. The gut is characterized by a $\mathrm{pH}$ close to neutrality (Nicodemus et al., 2002) and is the place where the most part of digestion and absorption take place. The digestibility of total dietary amino acid and starch reaches 80 to $100 \%$ at the end of the ileum (García et al., 2005; Carabaño et al., 2009). The small intestine is connected to the caecum by the ileocecal valve. In weight, caecum represents $49 \%$ of the total digestive tract (Portsmouth, 1977). Similarly, to the stomach, the caecum is characterized by a thin muscular layer, its content is slightly acid with pH value ranging from 5.4 to 6.8 (García et al., 2002). Finally, we find the colon, which can be divided into the proximal colon (35 cm long) and the distal colon (80-100 cm long). The end of the proximal colon is highly enervated and acts as a pacemaker for the colon during hard faeces formation (Snipes et al., 1982). Carabaño et al. (2008) described that the gutassociated lymphoid tissue (GALT) and specialized cells (goblet or Paneth cells) regulate the interaction of the gut mucosa with the microbiota and develop the mechanisms of tolerance and protection against pathogens.

At birth, the stomach and the small intestine are the main components of the digestive tract (Sabatakou et al., 1999). From birth to 18-20 days of age, kits survive drinking a large amount of milk (12\% of their body weight in once-day nursing). At 18 days of age, young rabbits start to pick up solid food and to decrease their milk intake. Simultaneously, the caecum and colon develop faster than the rest of the digestive tract. From 3 to 7 weeks of age, the caecum is filled by digesta and microbiota reaching its peak at 7-9 weeks of age $(6 \%$ of the total body weight; Carabaño et al., 2010). Similarly, the pH value of caecum decreases from 6.8 at 15 days of age to 5.6 at 50 days of age (Padilha et al., 1995). 
Numerous changes in the morphologic and functional maturation of the digestive system occur during the change from milk to solid feeding. During the suckling period, the gastric lipase is responsible for the lipolytic activity of the whole digestive tract, and similarly, the proteolytic activity is localized in the stomach (Marounek et al., 1995). The mucosal glands produce lactase, and sucrase and maltase until 25 and 28-32 days of age, respectively (Gutiérrez et al., 2002). There is a common agreement that from 21 to 42 days of age, the digestive functionality is limited to the lipase, amylase secreted by the pancreas and other enzymes secreted by the gastric and intestinal mucosa, allowing young rabbits (35 days old) to digest 0.9-0.96 of starch in the end of the ileum (Gómez-Conde et al., 2007). Other enzymes appear with age as rabbits start to eat solid feed due to the presence of intestinal microflora, such as cellulase, pectinase, xylanase and urease. Furthermore, the intestinal microbiota is very important for rabbit's immune system, since they promote GALT development and the somatic diversification of immunoglobulins (Rhee et al., 2004) and therefore, the first antibody repertoire is generated and developed from 4 to 8 weeks of age in the GALT (Mage et al., 2006). Thus, both the age of weaning and the composition of the solid feed are very important in determining digestive microbiota and health status during the fattening period.

The colonisation of the digestive system in rabbits starts as in other animal species and humans, by contamination from the birth canal and the external environment followed by a succession of microbial composition development specific to the host species (Berg, 1996). In general, the bacteria community in rabbits, evolve from a few very abundant species with high within-group distance to more, but less abundant, species with a lower within-group distance (Combes et al., 2011). As demonstrated by Combes et al. (2011), archaeal community, characterised with its methanogenesis activity, is detected one week after birth and tended to increase with age. While the bacterial community is 
detected starting from the second day after birth and reached its maximum the day 21 after birth, the Bacteroides-Prevotella copy number increased from day 14 to 21 and then started to decrease from 35 to 70 days of age, while the Firmicutes number doesn't change from 14 and 70 days of age. The microbial community in rabbits is dominated by Bacteroidetes and Firmicutes representing 4 and $94 \%$ of the sequenced clone (Monteils et al., 2008). The previous statements implicate that the stable state is reached in the subadult age, but until the postweaning period the rabbit digestive microbiota is relatively more susceptible to disturbance, being widely affected by external factors such as weaning age and the solid feed intake and composition, as well as the farm ecosystem (Thompson et al., 2008).

\section{Dietary strategies targeting better digestive health in rabbits}

\subsection{Feed intake regulation: feed restriction}

Relationship between feed intake and digestive troubles incidence during the growing period has been largely studied especially in cases of ERE outbreaks (Boisot et al., 2003). It seems that reducing the feed intake by restriction strategies after weaning is a successful methodology to significantly reduce diarrhoea prevalence and thus morbidity and mortality rates (Gidenne and Feugier, 2009; Gidenne et al., 2009; Gidenne et al., 2012). In these previous studies, the linear decrease of the intake (80, 70 and $60 \%$ of the ad libitum) during 20 days after weaning linearly reduced the growth of young rabbits, but improving the feed conversion ratio (FCR) as a result of a better digestive efficiency associated to a slow passage of digesta through the digestive tract. Moreover, restriction increased moderately the liquid phase, increased volatile fatty acids concentration, especially that of butyrate, and decreased $\mathrm{pH}$ in the caecum. After the restriction period, rabbits usually go through a transitory period of 4 days of increased ingestion and then they receive feed ad libitum again. In this last period, rabbits exhibit a compensatory growth, making the difference between the more restricted (60\% of the ad libitum) and ad libitum feed rabbits only $200 \mathrm{~g}$ in the final 
body weight (Gidenne et al., 2009). This strategy seems to be successful in the French breeding system since it is largely adapted by professional breeders. Feed restriction strategies are extended to limit the intake level through a time restriction for water consumption (Boisot et al., 2004; Verdelhan et al., 2004), but most of them are based on the direct restriction of the feed. However, its application in other rabbit breeding systems still limited due to their genetic lines, slaughtering age, the national market, price and even to animal welfare legislation, since that rabbits are submitted to hunger.

Other ideas come up later, Knudsen et al. (2014) proposed to compensate lower growth and slaughter yield in case of feed restriction by using high energy diets (10.13 vs. $9.08 \mathrm{MJ} / \mathrm{kg}$ ). This system proposes limiting feed intake at $75 \%$ of the ad libitum during 31 days after weaning before going back to the ad libitum until slaughter age (7-10 days later). And so, this system increased faecal digestibility of dry matter (DM), crude protein (CP) and neutral detergent fibre (NDF) only during the restriction period, improved FCR (11\%) and decreased the health risk index. Otherwise, lower growth $(7 \%)$ was obtained besides the fact that high energy diets increased morbidity in good health conditions and decreased in poor health conditions. Besides, the economic advantage is only reached when decreasing mortality and morbidity, which is not always the case.

\subsection{Feeding strategies}

Besides to therapeutic and management techniques (as feed restriction or weaning delay), feeding has been the principal pillar used to reduce the risk of the digestive problems. Feeding strategies have been mainly based on providing a feed with a chemical composition of low risk at a certain age (around weaning), with adequate physical characteristics (particle size).

Starch has been suspected to be associated with higher risk, as the presence of rapidly fermentable carbohydrates in the large intestine has been related to 
digestive disorders for a long time (Cheeke and Patton, 1980). However, starch is almost totally digestible in the ileum (>92\%; Gidenne and Blas, 2010) and low impact of starch on digestive health was observed when starch and fibre effects were separated (Gidenne et al., 2004; 2005). Similarly to starch, lipids are well digested in small intestine, presenting a range of $2-3 \%$ of the feed. High fat starter diets may increase the energy intake of young rabbits, providing them with good performance conditions able to favour better digestive maturation and immune system development (Gidenne and García, 2006). In addition, some mediumchain fatty acids, such as caprylic and caproic, have been reported to show in vitro antimicrobial activity on rabbit caecal microbiota (Marounek et al., 2002; Skrivanova and Marounek, 2006). Despite its importance, fat is not a relevant actor on the digestive health of young rabbits.

Fibres are the major component of the feed; they represent 40 to $50 \%$ of its composition (Gidenne et al., 2010) and it is demonstrated to have a direct effect on rabbit digestive health troubles, and thus on mortality and morbidity. Low fibre diets increase the incidence of diarrhoea and affect the microbial digestive ecosystem, especially the archaeal community (Bennegadi et al., 2003). In fact, only 5\% decreasing in the dietary NDF reduced caecal microbiota biodiversity (Nicodemus et al., 2004). All experiments dealing with starch/fibre ratio, whether varying both of them in different senses or fixing one of them and varying the other, confirmed that fibre level and quality play a key role on digestive disorders and diarrhoea incidence in weaned rabbits (Gidenne et al., 2000; García et al., 2004; Nicodemus et al., 2004; Blas et al., 1994; Bennegadi et al., 2001).

Finally, the protein level in a standard pelleted feed is around $14-19 \%$ for young rabbits (Gidenne, 2015). Protein is not only important for body growth but also for intestinal mucosa development and renewing. However, replacing dietary fibre with protein increased the digestive problems and diarrhoea in young rabbits (Gidenne et al., 2001). Accordingly, some nutritional strategies adopted 
in the field of rabbit nutrition were oriented to define dietary fibre and protein levels and qualities.

\subsubsection{Limitation of the protein intake}

Increasing the protein level in young rabbits diets, increase ileal $\mathrm{N}$ flux that generates high availability of nitrogenated substrates for microbial growth and high caecal $\mathrm{pH}$, increasing the prevalence of pathogenic species in the caecum especially as digestive maturation of these animals is not established yet (Gutiérrez et al., 2003; Nicodemus et al., 2003, 2004; Gómez-Conde et al., 2004a,b). Consequently, genera like Escherichia and Clostridium would find enough amino acids available to use them as substrates. Moreover, rabbits fed a soybean mealrich diet had a lower intake around weaning and higher serum anti-feed IgG levels respect to other protein sources (Cano et al., 2004), which may be a signal of sub-chronic inflammation provoking future digestive disorders. In fact, diets with high soybean meal levels (20\%) increased pre-weaning (35 days of age) mortality in rabbits (Scheele and Bolder, 1987). In addition, a substitution of soybean meal with animal plasma had a positive effect on intestinal mucosa morphology, feed intake, growth and survival (Gutiérrez et al., 2000). In this way, protein sources with less anti-nutritive substances and higher ileal digestibility, such as sunflower meal and soybean concentrate, seem to increase ileal protein digestion and decrease mortality (Gutiérrez et al., 2003; García-Ruiz et al., 2006). Also, the fact that kits, from an early age and before weaning, start to eat from their mothers' feed, which is richer in starch and protein content, may contribute to the future digestive problems. However, early-weaned (23d) rabbits, at two protein levels (180 and $210 \mathrm{~g} / \mathrm{kg}$ ), seems to have higher mortality rate and growth than conventional weaned rabbits ( $35 \mathrm{~d}$ ), probably associated to the protective role of the milk. Therefore, weaning age could have a greater effect on the digestive health and mortality rate than feeding strategy. In fact, Feugier et al. (2006) proposed to formulate the females' feed with no less than $190 \mathrm{~g} / \mathrm{kg}$ of acid 
detergent fibre (ADF) and no more than $180 \mathrm{~g} / \mathrm{kg}$ of $\mathrm{CP}$ to avoid negative effects on the digestive health status of young rabbits during the growing period.

\subsubsection{Insoluble and soluble fibre solutions}

The biochemical traits of dietary fibre depend on many factors, such as molecular weight, nature of monomers and type of linkages, as reviewed by Gidenne (2015). According to their location in the plant cell and their solubility in water, there is two main groups of dietary fibres: (1) the cell wall components with water soluble non-starch polysaccharides (non-starch soluble polysaccharides, part of $\beta$ glucans, arabinoxylans, part of pectins substances) and water insoluble polymers (lignins, cellulose, and some hemicelluloses and pectic substances); and (2) the cytoplasm components with indigestible polysaccharides, such as resistant starch, as well as fructans, mannans and oligosaccharides with a degree of polymerisation $<15$ (Gidenne, 2015). As mentioned above, the rabbit feed is usually formulated to contain from 40 to $50 \%$ of fibre. Fibre is considered as intake regulator, moderator of the rate of passage and fundamental substrate for microbiota growth and activity (Combes et al., 2013). Thus, fibre quantity and quality have been used as an effective tool to prevent post-weaning digestive troubles.

\section{Insoluble fibre}

The insoluble fibre fraction of the rabbit feed is the part that resist to digestion by the neutral detergent solution and called neutral detergent fibre "NDF" according to the Van-Soest procedure. The NDF fraction is composed of indigestible fractions such as lignin (ADL), a low digestible fraction such as celluloses (ADF-ADL), and a partially digestible fraction such as insoluble hemicelluloses (NDF-ADF). The effect of the different insoluble fibre fractions on the digestive health and the prevalence of diarrhoea in young rabbits has been largely studied (Gidenne, 2015; Gidenne et al., 2010a, b). Current recommendations for insoluble fibre content are defined as 30\% of NDF (de Blas 
et al., 2010), including 19 or $17 \%$ of ADF, 5.5 or $5 \%$ of ADL, 13 or $11 \%$ of cellulose and 12 or $10 \%$ of hemicelluloses for 28 to 42 and 42 to 70 days post-weaning, respectively (Gidenne, 2015).

In this way, the increasing of the lignocellulose fraction has been associated to a linear decrease in mortality rate and health risk index (HRi), defined as the sum of mortality and morbidity (Maître et al., 1990; Perez et al., 1994). Similarly, the effect of low fibre diets on the higher incidence of diarrhoea was also confirmed (Blas et al., 1994; Bennegadi et al., 2001). Likewise, increasing the cellulose intake reduces the mortality rate without any pronounced side effects on the passage rate (Perez et al., 1996; Gidenne and Perez, 1996). However, increasing the lignin intake decreased the HRi, but also decreased the digesta retention time, the feed digestibility and the growth rate besides to an increase of the FCR (Gidenne and Perez, 1996). Therefore, it is recommended to keep the ADL level under 5.5\% and to keep the lignin/cellulose ratio over 0.4 .

\section{Soluble fibre}

As mentioned above, insoluble hemicelluloses (calculated as NDF-ADF) are much more digestible than ADF fraction and cellulose. Besides, the part of the fibre that is soluble in the neutral detergent solution of the Van-Soest procedure, which can be calculated as the difference between the total dietary fibre (TDF) and the NDF values, is commonly called soluble fibre (SF) by many authors. Some authors (Gidenne, 2003) also proposed a fraction called digestible fibre fraction $(\mathrm{DgF})$ as that corresponding to the addition of high digestible hemicelluloses plus the water-soluble fibre. However, in the current thesis, it will be used the terms SF and digestible fibre when referring to the fibrous fraction soluble in NDF solution and the digestibility coefficient of the fibre, respectively. Soluble fibre plays a key role on the digestive health of young rabbit since it is highly fermented compared to lignocellulose. Its fermentation process time 
corresponds to the retention time of the caeco-colic segment (9-13 h, Gidenne, 1997). When replacing starch, in iso-ADF antibiotic free diets, SF decreased post weaning mortality (Perez et al., 2000). And when a sufficient amount of ADF $(18 \%)$ is provided, it will be favourable to replace a certain amount of starch by SF, which will increase slightly the FCR but also improve the HRi (Tazzoli et al., 2009; Trocino et al., 2011). When replacing protein in iso-ADF antibiotic free diets (Gidenne et al., 2001), SF significantly improved the digestive health status of growing rabbits, without a relevant effect on the growth performance (Xiccato et al., 2011; Gidenne et al., 2013). Increasing SF level in rabbit diet is reached through supplying raw materials rich in pectins (as sugar beet, citrus or apple pulps) or fructans (as chicory pulp). In fact, some positive physiological effects have been also related to pulp level itself. In fact, when sugar beet pulp level in the diet of growing rabbits is increased, digestibility of the insoluble fibre fractions (as NDF and $\mathrm{ADF}$ ) and the fermentation level were also increased and the caecal $\mathrm{pH}$ was decreased, which promotes the microbial activity (Trocino et al., 2013). Moreover, the SF level may modify the ileal and caecal microbiota through the modification of the type of substrates reaching the caecum (Gómez-Conde et al., 2007 and 2009). These changes in microbiota may also improve the immune response of young rabbits and promote better digestive health in cases of ERE. However, recent reviews (Trocino et al., 2013; Gidenne, 2015) exposed that due to the current analytical method used for SF determination, variability of mortality data, and other dietary characteristics (ADF, starch, protein...), it is complicated to obtain a mathematical relationship between SF level in the diet and postweaning mortality.

\section{Alternative dietary strategies}

Antibiotic resistance has become one of the greatest threats to global health. Thus, Scandinavian countries, with Sweden up the list in 1986, followed by the European Union in January 2006, have forbidden the use of antibiotics growth 
promoters (AGP). Knowing that, we should not confuse the antibiotic use as AGP or therapeutics. The AGP were used on low doses in long term administrations. On the contrary, therapeutic antibiotics are used on high doses in short term administrations, after illness diagnosis in high sanitary risk periods, such as the two first weeks after weaning in rabbits. While the AGP are totally banned, in rabbit industry we keep use the therapeutic antibiotics specially in critical periods. However, view their social and environmental dangerous sides, there is no doubt that their use will be limited in the coming few years. Antibiotics, despite the harm they could cause, they have many positive effects such as better feed efficiency and thus low feed usage per production unit, less amount of land needed for feedstuff production, and fewer imports of feedstuffs of many countries (Falcão-e-Cunha et al., 2007). This situation has made replacing antibiotics particularly challenging, being the search of alternatives highly promoted in the last decades. Large number of feed additives have been evaluated as alternatives to antibiotics but the most studied are enzymes, organic acids, probiotics, prebiotics and symbiotics.

\subsection{Enzymes}

Enzymes are globular proteins, that act as a catalyst in living organisms, regulating the rate at which chemical reactions proceed without itself being altered in the process. Almost all metabolic processes in the cell need enzyme catalysis in order to occur at rate fast enough to sustain life (Stryer et al., 2002). Enzymes are used in many processes in food technology, and it is in the 1950s when pioneering scientists added amylases and proteases to the diets of various farm animals and observed benefits in productivity. Since then, feed enzymes have become widely studied and used in animal nutrition (Adeola and Cowieson, 2011). Their mode of action might be related to the modification of the intestinal environment such as changes in the viscosity of the digesta (Lázaro et al., 2003), allowing better contact between nutrients, endogenous enzymes and 
the absorptive mucosa which increase the use and efficiency of the nutrients. Substances like non-starch polysaccharides may interfere with the digestion of nutrients contained in grains, dietary addition of cell-wall-degrading enzymes could be a solution releasing nutrients and facilitating their digestion (Cowan et al., 1996). In poultry and pigs, enzymes use is very successful and efficient (García et al., 2008). Rabbits digestive system is very efficient in nutrients utilization except for fibre. The digestive tract of 4 -weeks old rabbits contains most of the total activity of pectinase, amylase, lactase, xylanase, cellulase, $\beta$-glucosidase and urease which increases with age (Marounek et al., 1995). Available results from studying enzymes supplementation to rabbits diet could be summarised into: no effects at all (Falcão-e-Cunha et al., 2004; Pinheiro and Almeida, 2000), negative effect on nutrient digestibility when adding a protease (Bolis et al., 1996), or positive effects when adding a protease and carbohydrases (García-Palomares et al., 2006a,b; Chamorro et al., 2005). Therefore, proteases decreased post-weaning mortality the first 14 days of the growing period (García-Palomares et al., 2006a). An enzyme cocktail of $\beta$-glucanase, $\beta$-xylanase, $\alpha$-amylase and pectinase, when supplemented to 25 days weaned rabbits, improved digestibility, growth rate, feed efficiency from 25 to 39 days of age and decreased post-weaning mortality (García-Palomares et al., 2006b). Finally, xylanases and proteases increased ileal apparent digestibility and reduced the colony counts of highly pathogenic Clostridium (García-Palomares et al., 2006a).

\subsection{Organic acids}

Chemically, the term 'organic acids' refers to all those acids built on a carbon skeleton known as carboxylic acid. They can alter the physiology of bacteria causing metabolic disorders that prevent their proliferation and cause death (Theobald, 2019). However, those with a specific antimicrobial activity are mainly the short-chain fatty acids (C1-C7; Papatsiros et al., 2012) such as formic, propionic, lactic, acetic, butyric, sorbic or citric acids. They all form a source of 
energy for the cells except benzoic acid which has a different metabolic and absorption characteristic (Theobald, 2019). According to Roth and Kirchgessner (1988), their mode of action could be: reduction in the $\mathrm{pH}$ value and the buffering capacity, which increases antibacterial and antifungal effects in the feed, reduction of $\mathrm{pH}$ value by release of hydrogen ions in the stomach, thereby activating pepsinogen to form pepsin and improving protein digestibility, inhibition of gram-negative indigenous microflora in the gastro-intestinal tract, or improvement of the energetic utilization in the intermediate metabolism. Organic acids efficiency against pathogens growth depends on its pKa value. Those with high pKa could be effective preservatives for feed, such as propionic acid. Others with lower pKa values, such formic acid, will acidify the feed and the stomach but will not exercise a direct effect on intestine microflora (Theobald, 2019). Contrary to pigs' nutrition, where organic acids are largely studied and seems to be useful, there are few studies on the effect of organic acids on the digestive health of growing rabbits, with a lack of consistency, as reported by Maertens et al. (2006). Lebas and Camguilhem (1986) did not find any significant effect of the addition of $2 \%$ acetic acid in drinking water on the health of growing rabbit infected with $E$. coli 0103 . In this way, an inclusion of $1.5 \%$ of fumaric acid in the diet of growing rabbits tended to improve average daily gain (ADG) and FCR, but results were not statistically significant (Scapinello et al., 2001; Michelan et al., 2002; Hollister et al., 1990). However, the inclusion of caprylic acid (0.5\%) (Skøivanová and Marounek, 2002) or triacylglycerols of caprylic and capric acids (Skøivanová and Marounek, 2006) seem to be more promising since they decreased post-weaning mortality without affecting growth performance. A complex of butyric acids, calcium formate, organic acids and its salts called "BCOS" increased ADG and daily feed intake (DFI) of rabbits after weaning but without any effect on FCR and mortality (Viliene et al., 2017). Supplementation of $0.5 \mathrm{ml} / \mathrm{L}$ of citric acid or lactic acid in the drinking water of rabbits after weaning, decreased total anaerobic E. coli counts, caecum $\mathrm{pH}$ and caecal 
ammonia concentration while increased Lactobacilli counts and volatile fatty acids (VFA) concentration in the caecum (Elkelawy et al., 2017).

\subsection{Probiotics}

Probiotics are defined as "live microorganisms that, when administered in adequate amounts, confer a health benefit to the host" (Adami and Cavazzoni, 1999). Their mechanisms of action are suggested to be: a reduction of metabolic reactions which produce toxic substances, the stimulation of host enzymes, the production of vitamins or antimicrobial substances, the competition for adhesion to epithelial cells and increased resistance to colonization, and the stimulation of the immune system of the host (Ziemer and Gibson, 1998; Ouwehand et al., 1999; Simon et al., 2003). Like organic acids, probiotics has not been widely tested on rabbits in comparison to other monogastric animals. Dietary inclusion of a commercial product (Lacto-sacc), mainly including Lactobacillus acidophilus and Saccharomyces cerevisiae, did not affect the main performance traits of growing rabbits but it was related to an improvement on digestibility of crude fibre (CF, Yamani et al., 1992) and CP (Kamra et al., 1996). Dietary inclusion of $0.5 \mathrm{mg} / \mathrm{kg}$ of Lac-A-Bac (Lactobacillus acidophilus at 0.8 billion colony forming units (CFU)/g) improved the digestibility of energy, DM, CP, ether extract (EE) and CF, increased cellulotic bacteria counts $(\mathrm{CFU} / \mathrm{mL})$ and decreased that of ureolytic bacteria in caecum (Amber et al., 2004). However, other studies did not report effect on DFI when adding Enterococcus AL 41 strain (Chrastinova et al., 2010) and Bacillus subtilis and Bacillus lichenformis (Eiben et al., 2008). Concerning the effect of probiotics supplementation on rabbit health, and caecal microbiota available results are not consistent.

\subsection{Prebiotics}

The scientific community started to think about prebiotics in 1921, when Rettger and Cheplin founded that after carbohydrates consumption, the human intestinal microbiota was enriched with lactic bacteria. The definition of a dietary 
prebiotic has been evolving this last two decades but the current definition, according to Gibson et al. (2017), is "a selectively fermented ingredient that results in specific changes in the composition and or activity of the gastrointestinal microbiota, thus conferring benefit(s) upon health". The effect of prebiotics on microbiota was initially defined as a microbiota selective effect referring to improve Lactobacillus and Bifidobacteria populations. However, recent studies showed that, besides these populations, other groups such as Faecalibacterium prausinitzii, Anaerostipes spp, Bilophila spp, etc could be promoted, which means that the selectivity extent to several microbial groups but not all of them (Gibson and Roberfroid, 1995). Moreover, other interesting characteristic of some prebiotics is that they can prevent the adhesion of pathogens to the mucosa, by competing with its sugar receptors, and then they can directly stimulate the gut immune system (Forchielli and Walker, 2005). They can be extracted from natural sources, such as plants, legume, yeasts, milk..., or be produced by partial acid or enzymatic hydrolysis of polysaccharides or by trans glycosylation reactions (Oku, 1996).

The main oligosaccharides marketed as a prebiotic in our days are the fructooligosaccharides (FOS), the $\alpha$-galacto-oligosaccharides (GOS), the trans-galactooligosaccharides (TOS), the mannan-oligosaccharides (MOS) and the xilanooligosaccharides (XOS) (Falcão-e-Cunha et al., 2007). Comparing to enzymes and probiotics, prebiotics may be a better solution as an antibiotic alternative since, in general they escape the problem of thermal processing during the feed pelleting, they are not affected during the digestion process and there is no need to introduce foreign microbial species into the animals gut.

The main prebiotics have been tested on rabbits are FOS (Lebas, 1996; Mourão et al., 2004; Aguilar et al., 1996), GOS (Peeters et al., 1992; Gidenne, 1995), MOS (Mourão et al., 2006; Kocher, 2006; Fonseca et al., 2004; Pinheiro et al., 2004; Bovera et al., 2010 and 2012), inulin (Maertens et al., 2004) and fructans (Carabaño 
et al., 2001). However, as in the other alternatives presented, results are not consistent. Starting with FOS, Aguilar et al. (1996) observed that they showed a positive effect on ADG of growing rabbits, but in other studies they showed totally the opposite (Mourão et al., 2004) or no effect at all (Lebas, 1996). Morisse et al. (1992), support the barrier effect of FOS in the caecum reporting that the saprophyte E. coli population increased, the VFA production was increased and that of $\mathrm{N}-\mathrm{NH}_{3}$ was decreased. While other authors only observed an increase in VFA production when adding FOS to rabbit diet (Maertens et al., 2004). The potential interest of GOS seems to be less promising since they showed no effect in some studies (Peeters et al., 1992), and even negative on mortality and morbidity in others (Gidenne, 1995). From the results with MOS, it can be concluded that they seem to be a promising prebiotic for rabbits (Kocher, 2006), as they were efficient when compared to AGP (Fonseca et al., 2004; Pinheiro et al., 2004) and allowed to achieve similar performance traits. MOS act by preventing the attachment of pathogens' fimbriae to mannose residues of the intestinal cell receptors that being attached to MOS instead. They are also able to increase VFA concentration and increase the length of ileal villi (Mourão et al., 2006). Bovera et al. (2010 and 2012) observed that dietary inclusion of $10 \mathrm{~g} / \mathrm{kg}$ MOS increased caecal concentration of butyrate, acetate and branched-chain fatty acids, and reduced the count of coliforms comparing to the control and antibiotic groups. Finally, inulin supplementation had a positive effect on VFA concentration (Maertens et al., 2004; Volek et al., 2005 and 2007), and fructans could be hydrolysed by microbes in the upper intestine, especially during caecotrophy process (Carabaño et al., 2001). The possible inconsistency about the potential effect of these prebiotics could be related to differences on doses, farm hygienic conditions, composition of the prebiotics, administration period and time, and maybe the positive effects mainly appears in long terms treatments such as in human (Falcão-e-Cunha et al., 2007). In any case, the research with 
prebiotics seems to be promising, thus we must continue investigating the search for new prebiotics and their correct use in rabbits.

\section{Fenugreek seed gum: Galactomannan}

Trigonella foenum-graecum is an annual herb of the family of Fabaceae, usually cultivated in Asia and in North African countries but also in less quantity in Europe and known as fenugreek (fenogreco or alholva in Spain, alhilba in Tunisia). Fenugreek has been used since the antiquity in the traditional Arab medicine and with some works attributing possible functional properties as hypocholesterolemic, immunological enhancer, lactation aid, antibacterial, gastric stimulant, for anorexia, antidiabetic agent, hepatoprotective effect and even anticancer activity (Murlidhar and Goswami, 2012). Fenugreek is well known for its high fibre content, and the presence of alkaloids, flavonoids, saponins, volatile substances and gums. Leaves, herbs and seeds of fenugreek are sometimes avoided in animal nutrition because of the bad smell and taste residues in cattle's meat and milk and even in eggs (Bartley et al., 1981; Sewell et al., 1999; Korman et al., 2001; Mazza et al., 2002). However, in the case of gums, the smell residue will not be a limiting factor since it will be eliminated during the extraction process. Fenugreek seed gum (FSG) is an aqueous extract (Zemzmi et al., 2017) rich in galactomannan, which is a polysaccharide structurally composed of a (1-4)-linked $\beta$-D-mannopyranose backbone with branch points from their 6-positions linked to $\alpha$-D-galactose (Jiang et al., 2007). According to Majeed et al. (2018), fenugreek seeds gum contains 63.5\% of galactomannan with high fermentative potential, suitable to be used with probiotics in a symbiotic combination.

Galactomannans have been tested in different species. Their dietary inclusion improved intestinal characteristics at bacteriological and morphological level in pigs (Van Nevel et al., 2005), increased serum antibody against Newcastle disease virus in broilers (Wang et al., 2003) and exhibited a potential prebiotic effect when 
used with the appropriate exogenous enzymes in broilers (Kakani, 2013). In other species, like European sea bass (Dicentrarchus labrax), $0.2 \mathrm{~g} / \mathrm{kg}$ of galactomannan in a low fish meal and fish oil diet induced changes in the gut microbiota composition (Rimoldi et al., 2020). In this same species, when associated with phytogenics (garlic oil + labiatae-plants oils), galactomannan increased the relative abundance of Bacteroidales, Lactobacilliales and Clostridiales, and reduced coliforms and Vibronales resident bacteria orders. In addition, butyrate producer taxa increased. This fact is relevant since high butyrate levels have been associated to lower mortality when $7 \%$ of cellobiose was administrated to growing rabbits in drinking water (Ocasio-Vega et al., 2018).

Accordingly, galactomannan from fenugreek seeds gum could be a promising additive with a prebiotic potential when added in rabbit's diet in ERE conditions. In addition, it could be also a good tool to improve the digestive health in the rabbit breeding systems in the North-African countries. However, to date, there is no information on the potential of this product as a prebiotic in growing rabbits.

\section{References}

Adami A, Cavazzoni V. 1999. Occurrence of selected bacterial groups in the faeces of piglets fed with Bacillus coagulans as probiotic. Journal of Basic Microbiology, 39, 3-9.

Adeola O, Cowieson A. J. 2011. Board-invited review: opportunities and challenges in using exogenous enzymes to improve nonruminant animal production. Journal of animal science, 89, 3189-3218.

Aguilar J. C, Roca T, Sanz E. 1996. Fructo-oligosaccharides in rabbit diet. Study of efficiency in suckling and fattening periods. In: Proceedings of 6th World Rabbit Congress. Toulouse, France, 73-77.

Amber K. H, Yakout H. M, Hamed Rawya S. 2004. Effect of feeding diets containing yucca extract or probiotic on growth, digestibility, nitrogen balance and caecal microbial activity of growing new zealand white rabbits. In: Proceedings of the 8th World Rabbit Congress. Puebla, México, 737-741.

Bartley G. B, Hiltry M. D, Andreson B. D, Clairemont A. C, Maschke S. P. 1981. "Maplesyrup" urine odor due to fenugreek ingestion. The New England Journal of Medicine, 305, 467. 
Bennegadi N, Gidenne T, Licois L. 2001. Impact of fibre deficiency and health status on non-specific enteropathy of the growing rabbit. Animal Research, 50, 401-413.

Bennegadi N, Fonty G, Millet L, Gidenne T, Licois D. 2003. Effects of Age and Dietary Fibre Level on Caecal Microbial Communities of Conventional and Specific PathogenFree Rabbits. Microbial Ecology in Health and Disease, 15, 23-32.

Bennett R. M, Anderson J, Blaney R. J. P. 2002. Moral intensity and willingness to pay concerning farm animal welfare issues and the implications for agricultural policy. Journal of Agricultural and Environmental Ethics, 15, 187-202.

Berg D. 1996. The indigenous gastrointestinal microflora. Trends Microbial, 4, 430-435.

Blas E, Cervera C, Fernández Carmona J. 1994. Effect of two diets with varied starch and fibre levels on the performances of 4-7 weeks old rabbits. World Rabbit Science, 2, 117-121.

Boisot P, Licois D, Gidenne T. 2003. Feed restriction reduces the sanitary impact of an experimental reproduction of Epizootic Rabbit Enteropathy syndrome (ERE), in the growing rabbit. In: Proceedings of the 10ème Journée de Recherche Cunicoles France, G. Bolet (Ed.). ITAVI publ. 267-270.

Boisot P, Duperray J, Dugenétais X, Guyonvarch A. 2004. Interest of hydric restriction times of 2 and 3 hours per day to induce feed restriction in growing rabbits. In: Proceedings of the $8^{\text {th }}$ World Rabbit Congress, C. Becerril and A. Pro (Eds.). Puebla, Mexico, 759764.

Bolis S, Castrovilli C, Rigoni M, Tedesco D, Luzi F. 1996. Effect of enzyme addition in diet on protein and energy utilization in rabbit. In: Lebas, F. (ed.) Proceedings of the $6^{\text {th }}$ World Rabbit Congress, Toulouse. Association Française de Cuniculture. Lempdes, France, pp. $111-115$.

Bovera F, Marono S, Di Meo C, Piccolo G, Iannaccone F, Nizza A. 2010. Effect of mannanoligosaccharides supplementation on caecal microbial activity of rabbits. Animal, 4, 1522-1527.

Bovera F, Lestingi A, Marono S, Iannaccone F, Nizza S, Mallardo K, de Martino L, Tateo A. 2012. Effect of dietary mannan-oligosaccharides on in vivo performance, nutrient digestibility and caecal content characteristics of growing rabbits. Journal of Animal Physiology and Animal Nutrition, 96, 130-136.

Cano J. L, Blas E, Soler M. D, Moya V. J, Guillen M. I. 2004. Immune response induced by feed in growing rabbits. In: Proceedings of the $8^{\text {th }}$ World Rabbit Congress, C.M. Becerril and A. Pro (Eds.). Puebla, Mexico, 765-770. 
Carabaño R, García J, de Blas J.C. 2001. Effect of fibre source on ileal apparent digestibility of non-starch polysaccharides in rabbits. Animal Science, 72, 343-350.

Carabaño R, Piquer J, Menoyo D, Badiola I. 2010. The digestive of the rabbit. Nutrition of the Rabbit (ed 2), de Blas C and Wiseman J. 1-18.

Carabaño R, Villamide M. J, García J, Nicodemus N, Llorente A, Chamorro S, Menoyo D, García-Rebollar, García-Ruiz A. I, de Blas J. C. 2009. New concepts and objectives for protein-amino acid nutrition in rabbits: a review. World Rabbit Science, 17, 1-14.

Carabaño R, Badiola I, Chamorro S, García J, García-Ruiz A. I, García-Rebollar P, GómezConde M. S, Gutiérrez I, Nicodemus N, Villamide M. J, de Blas J. C. 2008. Review. New trends in rabbit feeding: influence of nutrition on intestinal health. Spanish Journal of Agriculture Research, 6, 15-25.

Chamorro S, Gómez-Conde M. S, Pérez de Rozas A. M, Badiola I, Carabaño R, de Blas. 2005. Efecto del nivel y tipo de proteína en piensos de gazapos sobre parámetros productivos y salud intestinal. In: Proceedings of the XXX Symposium de Cunicultura. Valladolid, Spain, pp. 135-142.

Cheeke P. R, Patton N. M. 1980. Carbohydrate-overload of the hindgut. A probable cause of enteritis. Journal of Applied Rabbit Research, 3, 20-23.

Chrastinová L. U, Chrenková M, Lauková A, Poláčiková M, Simonová M, Szabóová R, Strompfová V, d’ Ondruška, Chlebec I, Parkányi V, Rafay J, Vasilková Z. 2010. Influence of selected phytoadditives and probiotics on zootechnical performance, caecal parameters and meet quality of rabbits. Archiva Zootechnica, 13, 30-35.

Combes S, Dalle Zotte A. 2005. Rabbit meat: Dietetic properties and processing characteristics. In: Proceedings of the $11^{\text {ème }}$ Journées de la Recherche Cunicole. Paris, France, 167-180.

Combes S, Fortun-Lamothe L, Cauquil L, Gidenne T. 2013. Engineering the rabbit digestive ecosystem to improve digestive health and efficacy. Animal, 7, 1429-1439.

Combes S, Michelland R. J, Monteils V, Cauquil L, Soulié V, Tran N. U, Fortun-Lamothe L. 2011. Postnatal development of the rabbit caecal microbiota composition and activity. FEMS microbiology ecology, 77, 680-689.

Cowan W. D, Jorsbak A, Hastrup T, Rasmussen P. B. 1996. Influence of added microbial enzymes on energy and protein availability of selected feed ingredients. Animal Feed Science and Technology 60, 311-319.

de Blas Beorlegui C, Mateos G. G, Rebollar P. G. 2010. Tablas FEDNA de composición y valor nutritivo de alimentos para la fabricación de piensos compuestos. Fundación Española para el Desarrollo de la Nutrición Animal. 
Eiben C. S, Gippert T, Gódor-Surmann K, Kustos K. 2008. Feed additives as they affect the fattening performance of rabbits. In: Proceedings of the $9^{\text {th }}$ World Rabbit Congress. Verona, Italy, 10-13 June 2008, 625-630.

Elkelawy H, Nassrallah M, Mahmoud N, Mobarez S, Mohamed M. 2017. Impact of adding citric, lactic acids and propylene glycol. 1. growing rabbits' performance. Egyptian Journal of Rabbit Science, 27, 309-323.

Falcão-e-Cunha L, Reis J, Freire J. B, Castro-Solla L. 2004. Effects of enzyme addition and source of fibre on growth and fibrolytic activities of growing-finishing rabbits. In: Proceedings of the $8^{\text {th }}$ World Rabbit Congress, Puebla, México, 1532-1537.

Falcão-e-Cunha L, Solla L. C, Maertens L, Marounek M, Pinheiro V, Freire J, Mourão J. L. 2007. Alternatives to antibiotic growth promoters in rabbit feeding: a review. World Rabbit Science, 15, 127-140.

Feugier A, Smit M. N, Fortun-Lamothe L, Gidenne T. 2006. Fibre and protein requirements of early weaned rabbits and the interaction with weaning age: effects on digestive health and growth performance. Animal Science, 82, 493-500.

Fonseca A. P, Falcão-e-Cunha L, Kocher A, Spring P. 2004. Effects of dietary mannan oligosaccharide in comparison to oxytetracyclin on performance of growing rabbits. In: Proceedings of $8^{\text {th }}$ World Rabbit Congress, Puebla, México, 829-833.

Forchielli M. L, Walker W. A. 2005. The role of gut-associated lymphoid tissues and mucosal defence. British Journal of Nutrition, 93, 41-48.

García A. I, de Blas J. C, Carabaño R. 2005. Comparison of different methods for nitrogen and amino acid evaluation in rabbit diets. Animal Science: an international journal of fundamental and applied research.

García J, Gidenne T, Falcão-e-Cunha L, de Blas J. C. 2002. Identification of the main factors that influence caecal fermentation traits in growing rabbits. Animal Research, 51, 165-173.

García J, Gómez M. S, Chamorro S, Nicodemus N, de Blas C, Carabaño R. 2004. Nuevas herramientas para la valoración nutritiva de los piensos de conejos recién destetados: implicaciones prácticas. Cunicultura, 170, 223-228.

García M, Lázaro R, Latorre M. A, Gracia M. I, Mateos G. G. 2008. Influence of enzyme supplementation and heat processing of barley on digestive traits and productive performance of broilers. Poultry Science, 87, 940-948.

García-Palomares J, Carabaño R, García-Rebollar P, de Blas C, Corujo A, García Ruíz A. I. 2006a. Effects of a dietary protein reduction and enzyme supplementation on growth performance in the fattening period. World Rabbit Science, 14, 231-236. 
García-Palomares J, Carabaño R, García-Rebollar P, de Blas J. C, García A. I. $2006 b$. Effects of dietary protein reduction during weaning on the performance of does and suckling rabbits. World Rabbit Science 14, 23-26.

García-Ruiz A. I, García J, Corrent E, Chamorro, S, García-Rebollar P, de Blas C, Carabaño R. 2005. Effet de l'âge du lapin, de la source de protéine et de l'utilisation d'enzymes sur les digestibilités apparentes de la matière sèche et de la protéine brute sur un aliment lapin. In : Proceedings of 11 $1^{\text {ème }}$ Journées de la Recherche Cunicole. Paris, France, 197-200.

Gibson G. R, Roberfroid M. B. 1995. Dietary modulation of the human colonic microbiota: introducing the concept of prebiotics. Journal of Nutrition. 125, 1401-1412.

Gibson G. R, Hutkins R, Sanders M. E, Prescott S. L, Reimer R. A, Salminen S. J, Scott K, Stanton C, Swanson K. S, Cani P. D, Verbeke K, Reid G. 2017. Expert consensus document: The International Scientific Association for Probiotics and Prebiotics (ISAPP) consensus statement on the definition and scope of prebiotics. Nature reviews Gastroenterology and Hepatology, 14, 491.

Gidenne T. 1995. Effect of fibre level reduction and gluco-oligosaccharide addition on the growth performance and caecal fermentation in the growing rabbit. Animal Feed Science Technology, 56, 253-263.

Gidenne T. 1997. Caeco-colic digestion in the growing rabbit: impact of nutritional factors and related disturbances. Livestock Production Science, 51, 73-88.

Gidenne T. 2003. Fibres in rabbit feeding for digestive troubles prevention: respective role of low-digested and digestible fibre. Livestock Production Science, 81, 105-117.

Gidenne T, García J. 2006. 4.3. Nutritional strategies improving the digestive health of the weaned rabbit. Recent Advances in Rabbit Sciences, 20, 229.

Gidenne T. 2015. Dietary fibres in the nutrition of the growing rabbit and recommendations to preserve digestive health: A review. Animal, 9, 227-242. doi:10.1017/S1751731114002729.

Gidenne T, Perez J. M. 1996. Dietary cellulose for the growing rabbit. I. Consequences on digestion and rate of passage. Annales de Zootechnie, 45, 289-298.

Gidenne T, Feugier A. 2009. Feed restriction strategy in the growing rabbit. 1. Impact on digestion, rate of passage and microbial activity. Animal, 3, 501-508.

Gidenne T, Blas E. 2010. Digestion of sugars ad starch. In Nutrition of the rabbit (ed. C de Blas and J Wiseman), 19-38. CABI Publishing, Wallingford, UK. 
Gidenne T, Pinheiro V, e Cunha L. F. 2000. A comprehensive approach of the rabbit digestion: consequences of a reduction in dietary fibre supply. Livestock Production Science, 64(2-3), 225-237.

Gidenne T, García J, Lebas F and Licois D. 2010b. Nutrition and feeding strategy: interactions with pathology. In Nutrition of the rabbit (ed. C de Blas and J Wiseman), 179199. CABI Publishing, Wallingford, UK.

Gidenne T, Lebas F, Fortun-Lamothe L. 2010a. Feeding behaviour of rabbits. In Nutrition of the rabbit (ed. C de Blas and J Wiseman), 233-252. CABI Publishing, Wallingford, UK.

Gidenne T, Combes S, Fortun-Lamothe L. 2012. Feed intake limitation strategies for the growing rabbit: Effect on feeding behaviour, welfare, performance, digestive physiology and health: A review. Animal, 6, 1407-1419.

Gidenne T, Kerdiles V, Jehl N, Arveux P. Briens C. 2001. Effet d'une hausse du ratio fibres digestibles/protéines sur les performances zootechniques et l'état sanitaire du lapin en croissance : résultats préliminaires d'une étude multi-site. In : Proceedings of the gème Journées de la Recherche Cunicole, Paris, 28-29 Novembre 2001, 65-68.

Gidenne T, Mirabito L, Jehl N, Perez J. M, Arveux P, Bourdillon A, Briens C, Duperray J, Corrent E. 2004. Impact of replacing starch by digestible fibre, at two levels of lignocellulose, on digestion, growth and digestive health of the rabbit. Animal Science, 78, 389-398.

Gidenne T, Jehl N, Perez J. M, Arveux P, Bourdillon A, Mousset J. L, Duperray J, Stephan S, Lamboley B. 2005. Effect of cereal sources and processing in diets for the growing rabbit. II. Effects on performances and mortality by enteropathy. Animal Research, 54, 6572.

Gidenne T, Kerdiles V, Jehl N, Arveux P, Eckenfelder B, Briens C, Stephan S, Fortune H, Montessuy S and Muaz G. 2013. Protein replacement by digestible fibre in the diet of growing rabbits: 2. Impact on performances, digestive health and nitrogen output. Animal Feed Science and Technology, 183, 142-150.

Gidenne T, Combes S, Feugier A, Jehl N, Arveux P, Boisot P, Briens C, Corrent E, Fortune H, Montessuy S, Verdelhan S. 2009. Feed restriction strategy in the growing rabbit. 2. Impact on digestive health, growth and carcass characteristics. Animal, 3, 509-515.

Gómez-Conde M. S, Chamorro S, Nicodemus N, de Blas C, García J, Carabaño R. 2004a. Efecto del tipo de fibra en la alimentación de gazapos destetados precozmente. In: Proceedings of XXIX Simposium de Cunicultura, Lugo, Spain, ASESCU publ. 157-163. 
Gómez-Conde M. S, Chamorro S, Nicodemus N, García J, Carabaño R, de Blas C. 2004b. Effect of the level of soluble fibre on ileal apparent digestibility at different ages. In: Proceedings of the $8^{\text {th }}$ World Rabbit Congress, C. Becerril and A. Pro (Eds.), Puebla, Mexico, 710 September, 130.

Gómez-Conde M. S, Garcia J, Chamorro S, Eiras P, Rebollar P. G, de Rozas A. P, Badiola I, de Blas C, Carabaño R. 2007. Neutral detergent-soluble fibre improves gut barrier function in twenty-five-day-old weaned rabbits. Journal of Animal Science 85, 3313-3321.

Gómez-Conde M.S, De Rozas A. P, Badiola I, Pérez-Alba L, de Blas C, Carabaño R and García J. 2009. Effect of neutral detergent soluble fibre on digestion. Livestock Science, 125, 192-198.

Groupement Interprofessionnel de Production Avicole et Cunicole (GIPAC). 2019. http://www.gipac.tn/.

Gutiérrez I, Cachaldora P, Carabaño R, de Blas J.C. 2000. Effect of supplementation with animal plasma and antibiotics of starter diets in rabbits. World Rabbit Science, 8, 269-275.

Gutiérrez I, Espinosa A, García J, Carabaño R, de Blas C. 2002. Effect of levels of starch, fibre, and lactose on digestion and growth performance of early-weaned rabbits. Journal of Animal Science, 80, 1029-1037.

Gutiérrez I, Espinosa A, García J, Carabaño R, de Blas C. 2003. Effect of protein source on digestion and growth performance of early-weaned rabbits. Animal Research, 52, 461471.

Hollister A. G, Cheeke P. R, Robinson K. L, Patton N. M. 1990. Effects of dietary probiotics and acidifers on performance of weanling rabbits. Journal of Applied Rabbit Research, 13, 6-9.

Jiang J. X, Zhu L. W, Zhang W. M and Sun R.C. Characterization of Galactomannan Gum from Fenugreek (Trigonella foenum-graecum) seeds and its rheological properties. International Journal of Polymeric Materials and Polymeric Biomaterials. 2007, 56, 1145.

Kakani R. 2013. Prebiotic properties of yeast cell wall mannanoligosaccharides and guar gum galactomannans in starting broilers. Doctoral dissertation, Texas A \& M University.

Kamra D. N, Chaudhary L. C, Singh R, Pathak N. N. 1996. Influence of feeding probiotics on growth performance and nutrient digestibility in rabbits. World Rabbit Science, 4, 8588.

Knudsen C, Combes S, Briens C, Coutelet G, Duperray J, Rebours G, Salaun J. M, Travel A, Weissman D. Gidenne T. 2014. Increasing the digestible energy intake under a 
restriction strategy improves the feed conversion ratio of the growing rabbit without negatively impacting the health status. Livestock Science, 169, 96-105.

Kocher A. 2006. Interfacing gut health and nutrition: the use of dietary pre- and probiotics to maximise growth performance in pigs and poultry. In D. Barug, J. de Jong A. K, Kies M. W. A. Verstegen (Eds.) Antimicrobial Growth Promoters. Wageningen Academic Publishers, The Netherlands, 289-310.

Korman S. H, Cohen E, Preminger A. 2001. Pseudo-maple syrup urine disease due to maternal prenatal ingestion of fenugreek. Journal of Pediatrics and Child Health, 37, 403404.

Lagerkvist C. J, Hess S. 2011. A meta-analysis of consumer willingness to pay for farm animal welfare. European Review of Agricultural Economics, 38, 55-78.

Lázaro R, García M, Araníbar M. J, Mateos G. G. 2003. Effect of enzyme addition to wheat-, barley- and rye-based diets on nutrient digestibility and performance of laying hens. British Poultry Science 44, 256-265.

Lebas F. 1996. Effects of fruct-oligo-saccharides origin on rabbit's growth performance in 2 seasons. In: Proceedings of the $6^{\text {th }}$ World Rabbit Congress. Toulouse, France, 211-215.

Lebas F, Camguilhem R. 1986. Infection experimentale de lapereaux en engraissement avec une souche d'Escherichia coli serogroupe 0-103 : effets de la teneur en cellulose de l'aliment et de l'addition d'acide acetique dans l'eau de boisson. In : Proceedings of the $4^{\text {ème }}$ Journées de la Recherche Cunicole, Paris, France, 341-349.

Lebas F, Coudert P. 1997. Entérocolite : les données récentes. Cuniculture 24, 269-272.

Lukefahr S. D. 2004, September. Sustainable and alternative systems of rabbit production. In: Proceedings of the $8^{\text {Th }}$ World Rabbit Congress, 8.

Maertens L, Aerts J, De Boever J. 2004. Degradation of dietary oligofructose and inulin in the gastrointestinal tract and the effects on $\mathrm{pH}$ and volatile fatty acids. World Rabbit Science, 12, 235-246.

Maertens L, Falcão-e-Cunha L, Marounek M. 2006. Feed additives to reduce the use of antibiotics. In: L. Maertens and P. Coudert (Eds.) Recent Advances in Rabbit Science. ILVO, Melle, Belgium, 259-265.

Mage R. G, Lanning D, Knigh K. L. 2006. B cell and antibody repertoire development in rabbits: the requirement of gut-associated lymphoid tissues. Developmental and Comparative Immunology 30, 137-153.

MAGRAMA. 2020. Informe trimestral indicadores del sector cunícola. Subdirección General de Producciones Ganaderas. Y Cinegéticas Dirección General de Producciones 
y Mercados Agrarios. Ministerio de Agricultura, Pesca y Alimentación, Secretaría General Técnica, Centro de Publicaciones, Madrid 2020. https://www.mapa.gob.es/es/ganaderia/estadisticas/dashboardcunicultura2trimestre2020 tcm30-511503.pdf.

Majeed M, Majeed S, Nagabhushanam K, Arumugam S, Natarajan S, Beede K, Ali F. 2018. Galactomannan from Trigonella foenum-graecum L. seed, Prebiotic application and its fermentation by the probiotic Bacillus coagulans strain MTCC 5856. Food science $\mathcal{E}$ nutrition, 6, 666-673.

Maître I, Lebas F, Arveux P, Bourdillon A, Dupperay J and Cast Y. 1990. Growth and mortality of the growing rabbit according to the level of lignocellulose (ADF-Van Soest).

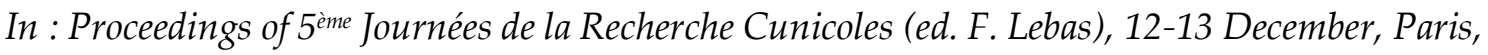
France, 2, 56.1-5.11. ITAVI Publications, Paris.

Marlier D, Denrée R, Lassence C, Licois D, Mainil J, Coudert P, Vindevogel H. 2005. Infectious agents associated with epizootic rabbit enteropathy: isolation and attempts to reproduce the syndrome. The Veterinary Journal, 172, 493-500.

Marounek M, Skrivanova V, Savka O. 2002. Effect of caprylic, capric and oleic acid on growth of rumen and rabbit caecal bacteria. Journal of Animal and Feed Science, 11, 507516.

Marounek M, Vovk S. J, Skrinova V. 1995. Distribution of activity of hydrolytic enzymes in the digestive tract of rabbits. British Journal of Nutrition, 73, 436-469.

Mazza G, Di Tommaso D, Foti S. 2002. Volatile constituents of Sicilian fenugreek (Trigonella foenum-graceum L.) seeds. Sciences des Aliments, 22, 249-264.

Michelan A. C, Scapinello C, Natali M. R. M, Furlan A. C, Sakaguti E. S, Faria H. G, Santolin M. L. R, Hernandes A. B. 2002. Utilização de probiotico, ácido orgânico e antibiótico em dietas para coelhos em crescimento: ensaio de digestibilidade, avaliação da morfometria intestinal e desempenho. Revista Brasileira de Zootecnia, 31, 2227-2237.

Monteils V, Cauquil L, Combes S, Godon J. J, Gidenne T. 2008. Potential core species and satellite species in the bacterial community within the rabbit caecum. FEMS Microbiology Ecology, 66, 620-629.

Morisse J. P, Maurice R, Boilletot E, Cotte J. P. 1992. Assessment of the activity of a fructooligossaccharides on different caecal parameters in rabbit experimentally infected with E. coli 0.103. Journal of Applied Rabbit Research, 15, 1137-1137.

Mourão J. L, Alves A, Pinheiro V. 2004. Effects of fructooligosaccharides on performances of growing rabbits. In: Proceedings of the $8^{\text {th }}$ World Rabbit Congress. Puebla, México, 915-921. 
Mourão J. L, Pinheiro V, Alves A, Guedes C. M, Pinto L, Saavedra M.J, Spring P, Kocher A. 2006. Effect of mannan oligosaccharides on the performance, intestinal morphology and cecal fermentation of fattening rabbits. Animal Feed Science and Technology, 126, 107120.

Murlidhar M Goswami T. K. 2012. A Review on the functional properties, nutritional content, medicinal utilization and potential application of fenugreek. Journal of Food Processing and Technology, 3, 18.

Nicodemus N, Garcia J, Carabaño R, Blas J. C. 2002. Effect of inclusion of sunflower hulls in the diet on performance, disaccharidase activity in the small intestine and caecal traits of growing rabbits. Animal Science, 75, 237-243.

Nicodemus N, Gómez Conde M. S, Espinosa A, García J, Carabaño R, de Blas C. 2003. Efecto de la utilización de bacitracina de zinc y sulfato de apramicina sobre la digestión en gazapos destetados precozmente. In: Proc. XXVIII Symposium de Cunicultura. Alcañiz (Spain), 2-4 April. Ed. ASESCU, 163-170.

Nicodemus N, Pérez-Alba L, Carabaño R, de Blas C, Badiola I, Pérez de Rozas A, J. G. 2004. Effect of fibre and level of ground of fibre sources on digestión and ileal and caecal characterization of microbiota of early weaned rabbits. In: Proc. 8th World Rabbit Congr, C. Becerril and A. Pro (Eds.), Puebla, Mexico, 7-10 september, 143.

Ocasio-Vega C, Delgado R, Abad-Guamán R, Carabaño R, Carro M. D, Menoyo D, García J. 2018. The effect of cellobiose on the health status of growing rabbits depends on the dietary level of soluble fibre. Journal of animal science, 96, 1806-1817.

Oku T. 1996. Oligosaccharides with beneficial health effects: a Japanese perspective. Nutrition Reviews, 54, 59-66.

Ouwehand A. C, Kirjavainen P. V, Shortt C, Salminen S. 1999. Probiotics: mechanisms and established effects. International Dairy Journal, 9, 43-52.

Padilha M. T. S, Licois D, Gidenne T, Carré B, Fonty G. 1995. Relationship between microflora and caecal fermentation in rabbits before and after weaning. Reproduction Nutrition Development 35, 375-386.

Papatsiros V. G, Christodoulopoulos G, Filippopoulos L. C. 2012. The use of organic acids in monogastric animals (swine and rabbits). Journal of Cell and Animal Biology, 6, 154-159.

Peeters J. E, Maertens L, Geeroms R. 1992. Influence of galactooligosaccharides in zootechnical performance, cecal biochemistry and experimental colibacillosis O103/8+ in weanling rabbits. Journal of Applied Rabbit Research, 15, 1129-1136. 
Perez J. M, Gidenne T, Lebas F, Caudron I, Arveux P, Bourdillon A, Dupperay $\mathrm{J}$ and Messager B. 1994. Dietary lignins in growing rabbits. 2. Consequences on growth performances and mortality. Annales de Zootechnie, 43, 323-332.

Perez J. M, Gidenne T, Bouvarel I, Arveux P, Bourdillon A, Briens C, Le Naour J, Messager B, Mirabito L. 1996. Dietary cellulose for the growing rabbit. II Consequences on performances and mortality. Annales de Zootechnie, 45, 299-309.

Perez J. M, Gidenne T, Bouvarel I, Arveux P, Bourdillon A, Briens C, Le Naour J, Messager B and Mirabito L. 2000. Replacement of digestible fibre by starch in the diet of the growing rabbit. II. Effects on performances and mortality by diarrhoea. Annales de Zootechnie, 49, 369-377.

Pinheiro V, Almeida A. 2000. Efeito da adição de pentosanases em dietas para coelhos em crescimento sobre las performances zootécnicas, saúde dos animais, parâmetros fermentativos cecais e composição química do digesta ileal. In: Proceedings of the I Jornadas Internacionais de Cunicultura, Vila Real, Portugal, 209.

Pinheiro V, Alves A, Mourão J. L, Guedes C. M, Pinto L, Spring P, Kocher A. 2004. Effect of mannan oligosaccharides on the ileal morphometry and cecal fermentation of growing rabbits. In: Proceedings of the $8^{\text {th }}$ World Rabbit Congress, Puebla, México, 936-941.

Portsmouth J. I, 1977. The nutrition of the rabbits. In Haresign W, Swan H, Lewis D. (eds) Nutrition and the climatic environment. Butterworths, London, UK, pp. 93-111.

Rhee K. J, Sethupathi P, Driks A, Lanning D. K, Knight K. L. 2004. Role of commensal bacteria in development of gut-associated lymphoid tissues and preimmune antibody repertoire. The Journal of Immunology, 172, 1118-1124.

Rimoldi S, Torrecillas S, Montero D, Gini E, Makol A, Valdenegro V.V, Izquierdo M, Terova G. 2020. Assessment of dietary supplementation with galactomannan oligosaccharides and phytogenics on gut microbiota of European sea bass (Dicentrarchus Labrax) fed low fishmeal and fish oil-based diet. Plos one, 15, 0231494.

Rosell J. M, De la Fuente L. F, Badiola J. I, Fernández de Luco D, Casal J, Saco M. 2009. Study of urgent visits to commercial rabbit farms in Spain and Portugal during 19972007. World Rabbit Science, 17, 127-136.

Roth F. X, Kirchgessner M. 1998. Organic acids as feed additives for young pigs: Nutritional and gastrointestinal effects. Journal of Animal Feed Science, 7, 25-33.

Sabatakou O, Xylouri-Frangiadaki E, Paraskevakou E, Papatonakis K. 1999. Scanning electron microscopy of stomach and small intestine of rabbit during foetal and post-natal life. Journal of Submicroscopic Cytology and Pathology, 31, 107-114. 
Scapinello C, García de Faria H, Furlan A. C, Michelan A. C. 2001. Efeito da utilização de oligossacarídeo manose e acidificantes sobre o desempenho de coelhos em crescimento. Revista Brasileira de Zootecnia, 30, 1272-1277.

Scheele C. W, Bolder N. M. 1987. Health problems and mortality of young suckling rabbits in relation to dietary composition. Beekbergen: Centrum voor Onderzoek en Voorlichting voor de Pluimveehouderij. COVP mededeling, no. 455.

Sewell A. C, Mosandl A, and Bohles H. 1999. False diagnosis of maple syrup urine disease owing to ingestion of herbal tea. Massachusetts Medical Society, 341-769.

Shehu B. M, Ayo J. O, Ayanwale B. A, Jiya E. Z, Tsado D. N. 2014. Growth performance and nutrient digestibility of weaned rabbits fed diets supplemented with varying levels of baker's yeast (Saccharomyces cerevisiae). Journal of Agricultural and Rural Development, 17, 1619-1627.

Simon O, Vilfried V, Scharek L. 2003. Micro-organisms as feed additives -probiotics. In: Proceedings of the $9^{\text {th }}$ International Symposium on Digestive Physiology in Pigs, Banff, AB, Canada, 295-318.

Skøivanová V, Marounek M. 2002. Effect of caprylic acid on performance and mortality of growing rabbits. Acta Veterinaria Brno, 71, 435-439.

Skøivanová V, Marounek M. 2006. A note on the effect of triacylglycerols of caprylic and capric acid on performance, mortality, and digestibility of nutrients in young rabbits. Animal Feed Science Technology, 127, 161-168.

Snipes, R. L, Clauss, W, Weber, A. and Hörnicke H. 1982. Structural and functional differences in various divisions of rabbit colon. Cell and Tissue Research, 225, 331-346.

Statista Research Department. 2020. Consumo per cápita de carne de pollo en España en 2010-2018. https://es.statista.com/estadisticas/564488/consumo-per-capita-de-carne-depollo-en-espana/.

Stryer L, Berg J. M, Tymoczko J. L. 2002. Biochemistry (5th ed.). San Francisco: W.H. Freeman. ISBN 0-7167-4955-6. Szalo I. M, Lassence C, Licois D, Coudert P, Poulipoulis A, Vindevogel H, Marlier D. 2007. Fractionation of the reference inoculum of epizootic rabbit enteropathy in discontinuous sucrose gradient identifies aetiological agents in high density fractions. The Veterinary Journal, 173, 652-657.

Tazzoli M, Carraro L, Trocino A, Majolini D, Xiccato G. 2009. Replacing starch with digestible fibre in growing rabbit feeding. Italian Journal of Animal Science, 8, 148-250.

Theobald P. 2019. Principals of using organic acid in animal nutrition. https://www.dsm.com/anh/en/feedtalks/principles-organic-acids-animal-nutrition.html. 
Thompson C. L, Wang B, Holmes A. J. 2008. The immediate environment during postnatal development has long-term impact on gut community structure in pigs. The ISME journal, 2, 739-748.

Trocino A, García J, Carabaño R and Xiccato G. 2013. A meta-analysis of the role of soluble fibre in diets for growing rabbits. World Rabbit Science, 21, 1-15.

Trocino A, Fragkiadakis M, Majolini D, Carabaño R, Xiccato G. 2011. Effect of the increase of dietary starch and soluble fibre on digestive efficiency and growth performance of meat rabbits. Animal Feed Science and Technology, 165, 265-277.

Van Nevel C. J, Decuypere J. A, Dierick N. A. PhD and Koen Molly K. 2005. Incorporation of galactomannans in the diet of newly weaned piglets: Effect on bacteriological and some morphological characteristics of the small intestine. Archives of Animal Nutrition, 59, 123-138.

Verdelhan S, Bourdillon A, Morel-Saives A, Audoin E. 2004. Effect of a limited access to water on mortality of fattening rabbits. In: Proceedings of the $8^{\text {th }}$ World Rabbit Congress, C Becerril and A. Pro (Eds.), Puebla, Mexico, 1015-1021.

Viliene V, Raceviciute-Stupeliene A, Sasyte V, Slausgalvis V, Gruzauskas R, Al-Saifi, J. 2017. Influence of dietary inclusion of butyric acids, calcium formate, organic acids and its salts on rabbit's productive performance, carcass traits and meat quality. International Journal of Nutrition and Food Engineering, 11, 15-19.

Volek Z, Marounek M, Skrivanova V. 2005. Replacing starch by pectin and inulin in diet of early-weaned rabbits: effect on performance, health and nutrient digestibility. Journal of Animal and Feed Science 14, 327-337.

Volek Z, Marounek M, Skrivanova V. 2007. Effect of a starter diet supplementation with mannan-oligosaccharide or inulin on health status, caecal metabolism, digestibility of nutrients and growth of early weaned rabbits. Animal, 1, 523-530.

Wang J. Tan, Li D. F, Gong L. M, Cheng G. 2003. Effect of galactomannanoligosaccharides on the growth performance and immune function in broilers. Chinese Journal of Animal Science, 02.

Xiccato G, Trocino A, Majolini D, Fragkiadakis, M, Tazzoli M. 2011. Effect of decreasing dietary protein level and replacing starch with soluble fibre on digestive physiology and performance of growing rabbits. Animal, 5, 1179-1187.

Yamani K. A, Ibrahim H, Rashwan A. A, El-Gendy K.M. 1992. Effects of a pelleted diet supplemented with probiotic (LactoSacc) and water supplemented with a combination of probiotic and acidifier (Acid-Pak 4Way) on digestibility, growth carcass and 
physiological aspects of weanling New Zealand White rabbits. Journal of Applied Rabbit Research, 15, 1087-1100.

Zemzmi J, Mabrouki S, Abdouli H, Najar T. Preliminary characterization of fenugreek seeds gum for use as prebiotic in rabbits' nutrition. In: Proceedings of the $20^{\text {th }}$ International Symposium on housing and diseases of rabbits, fur providing animals and pet animals, 17-18 May 2017. Celle, Germany, 2017, 179-186.

Ziermer C. J, Gibson G. 1998. An overview of probiotics, prebiotics and symbiotics in the functional food concept: perspectives and futures strategies. Dairy Journal, 8, 473-479. 


\section{Objectives}


Considering the current problematic of the rabbit industry mentioned above, where post-weaning digestive disorders are frequent in the farms, mainly due to ERE outbreaks, and the urgent need to minimize the antimicrobials use as the only possible treatment, the main objective of this thesis was to study the possible utilisation of galactomannans from fenugreek seed gum as a feed additive, with a prebiotic effect, during the post-weaning period of young rabbits.

Therefore, the specific objectives of the present thesis were:

- Characterisation of FSG studying its chemical composition, galactose/mannose ratio, its resistance to in vitro enzymatic digestion and its response to rabbit caecal microbiota fermentation.

- Studying the effect of FSG gradual inclusion in soluble fibre rich diet and lignin rich diet on in vitro enzymatic digestion and rabbit caecal microbiota fermentation.

- Evaluation of the gradual inclusion of FSG in a commercial growing rabbit's diet in Tunisia and its preliminary effect on in vivo faecal digestibility and in vitro fermentation.

- Comparing the effect of $10 \mathrm{~g} / \mathrm{kg}$ inclusion of FSG in conventional and low risk diets on in vivo performance, nutrient digestibility and caecal environment of growing rabbits. 


\section{Chapter I}

Preliminary evaluation of fenugreek (Trigonella foenum-graecum) seed gum as a potential prebiotic for growing rabbits in Tunisia: effects on in vivo faecal digestibility and in vitro fermentation

\section{Zemzmi J'2, Ródenas L², Blas E², Abdouli H¹, Najar T², Pascual J.J²}

${ }^{1}$ Laboratory of Improvement \& Integrated Development of Animal Productivity \& Food Resources, Higher School of Agriculture of Mateur, University of Carthage, Route de Tabarka, 7030, Mateur, Tunisia Republic

2Institute for Animal Science and Technology, Universitat Politècnica de València, Camino de Vera, s/n, 46022, Valencia, Spain

${ }^{3}$ National Agronomic Institute of Tunisia, University of Carthage, Avenue de la République BP 77-1054, Amilcar, Tunisia Republic. 


\section{Abstract}

This study aims to determine the effect of dietary inclusion of fenugreek seed gum (FSG), rich in galactomannans, on nutrient apparent digestibility and caecal environment, as well as on in vitro caecal fermentation of growing rabbits in Tunisia. Three experimental diets were formulated including $0,0.25$ and $0.5 \%$ of FSG (FSG0, FSG0.25 and FSG0.5, respectively) for the in vivo trial and 0, 0.125, 0.25, 0.5 and $100 \%$ of FSG (FSG0, FSG0125, FSG0.25, FSG0.5 and FSG100, respectively) for the in vitro trial. In the in vivo trial, 45 weaned rabbits 31 days old (15 per treatment) were housed in individual cages until 94 days of age. Apparent digestibility coefficients were determined at two ages, from 38 to 41 and from 56 to 59 days old, and caecal traits were recorded after slaughtering. In the in vitro trial, the five experimental diets were incubated with a rabbit caecal inoculum. Gas production was measured and modelled until $72 \mathrm{~h}$, and the fermentation traits measured. Apparent faecal digestibility coefficients of main nutrients and main caecal environment traits were not significantly affected by the dietary inclusion of FSG ( $P>0.05)$. However, animals fed with FSG showed lower caecal $\mathrm{pH}(-0.15 ; \mathrm{P}<0.05)$ values. Regarding the in vitro fermentation, FSG100 increased asymptotic gas production $(+11.25, \mathrm{P}<0.001)$, sharpness of the switching characteristic of the profile $(+1.98, \mathrm{P}<0.001)$ and the maximum substrate degradation rate $(\mathrm{RM})(+0.188, \mathrm{P}<0.001)$, but decreasing the time after incubation at which half of the asymptotic amount of gas has been formed (-5.86, $\mathrm{P}<0.001)$ and at which RM occurs $(-4.53, \mathrm{P}<0.01)$. Likewise, FSG100 significantly decreased caecal pH (-1.035, $\mathrm{P}<0.001)$, lactic acid $(-9.51, \mathrm{P}<0.069)$ and $\mathrm{N}-\mathrm{NH}_{3}$ concentrations $(-12.81, \mathrm{P}<0.001)$. While it increased the total volatile fatty acids (VFA) production $(+43.15, \mathrm{P}<0.001)$. Gradual dietary inclusion of FSG from 0 to $0.5 \%$ only significantly increased total VFA production in the caecum $(+100$ $\mathrm{mmol} / \mathrm{L}$ per percentage point of FSG inclusion; $\mathrm{P}<0.05)$. In conclusion, FSG is highly and rapidly in vitro fermented by rabbit caecal bacteria. However, dietary 
inclusion of FSG up to $0.5 \%$, might be insufficient to affect the apparent digestibility and fermentation profile of growing rabbits to a great extent.

Keywords: Rabbit, in vivo, in vitro, fenugreek seed gum, faecal digestibility, caecal fermentation

\section{Introduction}

One of the main limitations and concerns in rabbit farming is the frequency of digestive disorders, especially after weaning. Rosell et al. (2009) described that $54.1 \%$ of the urgent visits to commercial rabbit farms in Spain and Portugal during 1997 to 2007 were due to digestive tract diseases. Under these circumstances, increasing the dietary soluble fibre content has shown to be an effective strategy to improve the integrity of the intestinal mucosa and modulate the intestinal microbiota of rabbits (Gómez-Conde et al., 2007; 2009; Trocino et al., 2013a). Thus, the inclusion of 20 to $30 \%$ of beet pulp (rich in soluble fibre) promotes caecal fermentation, promoting butyrate proportion, which is usually related with a reduced mortality associated with digestive disorders (MartínezVallespín et al., 2011; 2013). An alternative to a high inclusion of soluble fibrerich raw materials, which also increases other fibrous fractions or could increase the amount of protein linked to fibre, is the direct inclusion of a small amount of an isolated soluble fibre so that, acting as a prebiotic, it could allow to obtain these same effects (Falcão-e-Cunha et al., 2007). To this end, some works (Bónai et al., 2010; Volek and Marounek, 2011) have evaluated the dietary inclusion of inulin-type fructans from chicory extracts, which seems to affect caecal fermentative activity in growing rabbits, but without relevant positive effects on the growing performance and digestive health of the animals. In other works, the inclusion of mannan-oligosaccharides (Bovera et al., 2010) afforded a reduction in rabbit mortality and an improvement of growth performance, while the supplementation with gluco-oligosaccharides (Gidenne, 1995) had no effect on caecal fermentation pattern and even a negative effect on morbidity and 
mortality. Lack of consistency in the results obtained with prebiotics could be explained by differences in the trial conditions, the nature of the prebiotic used, or the amount of prebiotic added to feed (Falcão-e-Cunha et al., 2007). Trigonella foenum-graecum, known as fenugreek, is an annual herb of the Leguminosae family, originating in the Near East and widely produced in India and Northern Africa as a spice and forage crop. In Tunisia, fenugreek is widely cultivated in the North-western, Northern and North-eastern regions. However, despite its potential interest as forage, fenugreek use remains limited, perhaps because some works (Bartley et al., 1981; Sewell et al., 1999; Korman et al., 2001; Mazza et al., 2002) have associated its intake with an unpleasant taste in cattle's meat and milk, as well as a strong odour in human sweat and urine. Fenugreek seeds contain 30.6 and $20.6 \%$ of soluble and insoluble dietary fibre, respectively (Naidu et al., 2011). The main component of its soluble fibre is a galactomannan, which is a polysaccharide structurally composed of a main chain of $\beta$ - $(1,4)$-linked $d-$ mannopyranose, where $83.3 \%$ of the main chain is substituted at C-6 with a single residue of $\alpha$ - (1,6)-D-galactopyranose (Jiang et al., 2007). Fenugreek seed gum (FSG), which corresponds to the soluble fibre fraction, is obtained by aqueous extraction followed by ethanol precipitation (Zemzmi et al., 2017), which eliminates the odour problems of the product. This FSG contains $63.5 \%$ of this galactomannan, which can be a potential prebiotic due to its resistance to acid and pancreatic digestion and its high fermentability (Majeed et al., 2018). As an initial approach, the aim of this study was to determine the effect of dietary inclusion of FSG on the nutrient apparent digestibility and caecal environment of growing rabbits, as well as on in vitro caecal fermentation, to evaluate the potential of this product as a prebiotic for growing rabbits in Tunisian conditions.

\section{Materials and methods}

Galactomannan extraction 
Following the recommendations of Zemzmi et al. (2017), fenugreek seeds were ground to pass a $2 \mathrm{~mm}$ diameter mesh, defatted in hexane-isopropanol $(3 / 2, \mathrm{v} / \mathrm{v})$, extracted in distilled water for $24 \mathrm{~h}$ and precipitated with ethanol $95^{\circ}$. Then, the FSG extracted was washed with acetone and finally freeze-dried and ground into a white powder.

Diets

Experimental diets were obtained using as a basis a commercial feed, including as main ingredients alfalfa hay, wheat bran, soybean meal and barley grain. Using this basal diet, three experimental diets were formulated and pelleted including 0, 0.25 and $0.5 \%$ of FSG (FSG0, FSG0.25 andFSG0.5, respectively) for the in vivo trial and 0, 0.125, 0.25, 0.5 and 100\% of FSG (FSG0, FSG0125, FSG0.25, FSG0.5 and FSG100, respectively) for the in vitro trial. Chemical composition of the experimental diets is presented in Table 1.1.

Table 1.1 Chemical composition of the experimental diets (\% DM), including different levels of fenugreek seed gum (FSG), used both in the in vivo and in vitro fermentation trials.

\begin{tabular}{lcccccccc}
\hline & \multicolumn{3}{c}{ In vivo trial diets } & \multicolumn{5}{c}{ In vitro fermentation trial diets } \\
\cline { 2 - 8 } & FSG0 & FSG0.25 & FSG0.5 & FSG0 & FSG0.125 & FSG0.25 & FSG0.5 $^{\text {FSG } 00}$ \\
\hline FSG (g/kg) & 0.00 & 2.50 & 5.00 & 0.00 & 1.25 & 2.50 & 5.00 & 1000 \\
Dry matter (DM, \%) & 90.2 & 89.5 & 88.7 & 93.7 & 92.4 & 92.9 & 93.02 & 91.3 \\
Ash & 10.1 & 9.82 & 10.1 & 9.48 & 9.36 & 9.47 & 9.55 & 1.27 \\
Crude protein & 17.1 & 16.9 & 17.2 & 17.0 & 17.1 & 16.8 & 16.9 & 22.2 \\
Neutral detergent fibre & 42.0 & 42.4 & 43.4 & 41.7 & 43.0 & 43.1 & 41.6 & 73.1 \\
Acid detergent fibre & 24.6 & 24.5 & 25.3 & 24.7 & 25.9 & 26.0 & 25.1 & 13.3 \\
Lignin detergent fibre & 3.30 & 3.15 & 3.50 & 4.92 & 4.06 & 3.81 & 3.30 & 0.00 \\
Starch & 12.4 & 11.4 & 12.0 & 12.3 & 14.3 & 14.3 & 13.6 & 0.00 \\
Total dietary fibre & 46.0 & 46.2 & 48.8 & - & - & - & - & - \\
Soluble fibre & 6.90 & 6.56 & 6.89 & - & - & - & - & - \\
Ether extract & 2.65 & 2.63 & 2.73 & - & - & - & - & - \\
\hline
\end{tabular}




\section{Animals and housing}

The trial was carried out at the experimental farm of the Higher School of Agriculture of Mateur (Carthage University, Tunisia Republic). The experimental procedure was carried out following the recommendations of the European Group on Rabbit Nutrition (Fernández-Carmona et al., 2005) and the experimental protocols followed the Spanish Royal Decree 53/2013 on the protection of animals used for scientific purposes.

Forty-five weaned crossbreed rabbits (New Zealand White x Californian), at 31 days of age, were randomly assigned to one of the three treatments (15 rabbits/group). Animals were housed in individual cages $(78 \times 46 \times 23 \mathrm{~cm})$ from 31 to 94 days of age, equipped with a feeder and a drinker to provide free access to feed and water. The lighting schedule was $16 \mathrm{~h}$ light/ $8 \mathrm{~h}$ dark throughout the experimental trial. Weaned rabbits had a similar live weight at the beginning of the trial $(552.12 \pm 12.72,545 \pm 13.17$ and $550.13 \pm 12.73 \mathrm{~g}$ for FSG0, FSG0.25 and FSG0.5, respectively). Mortality and morbidity were daily controlled. Ten no morbide with a similar live weight rabbits per treatment were used to determine the individual apparent faecal digestibility coefficients for dry matter (DM), organic matter, crude protein (CP), neutral detergent fibre (NDF) and acid detergent fibre (ADF). Apparent digestibility coefficients for ether extract (EE), total dietary fibre (TDF) and soluble fibre (SF) were determined from the pool of faeces of each treatment. The digestibility trial was performed at two ages using the same group of animals, from 38 to 41 and from 56 to 59 days of age. Following the recommendations of Perez et al. (1995), faeces and feed intake were controlled for four days, by covering the bottom of the cage with perforated plastic bags to eliminate urine. Faeces were stored in identified sealed plastic bags and frozen at $-20^{\circ} \mathrm{C}$ until analysis. At 94 days of age, all animals were slaughtered between 8:00 and 10:00 am. After skin removal, pH value of caecal content was measured and an aliquot of caecal content was placed in a $45 \mathrm{~mL}$ plastic tube with $20 \mu \mathrm{L}$ of $10 \%$ 
$\mathrm{HgCl}_{2}$ to stop caecal fermentation and stored at $-20^{\circ} \mathrm{C}$ for subsequent determination of VFA profile, $\mathrm{N}-\mathrm{NH}_{3}$ and lactic acid content.

\section{In vitro fermentation}

The gas production kinetics of FSG diets were determined in an in vitro fermentation trial. Two New Zealand 70 days old rabbits were fasted overnight, with free access to water, before their slaughter between 8:00 and 10:00 am. Caecal contents from both animals were collected, mixed and stirred for few minutes. Finally, $100 \mathrm{~mL}$ of the mixed caecal content were homogenised under $\mathrm{CO}_{2}$ bubbling in $400 \mathrm{~mL}$ of solution A (including $10 \mathrm{~g} / \mathrm{L} \mathrm{KH_{2 }} \mathrm{PO}_{4}, 0.5 \mathrm{~g} / \mathrm{L}$ $\mathrm{Mg}_{2} \mathrm{SO}_{4} \cdot 7 \mathrm{H}_{2} \mathrm{O}, 0.5 \mathrm{~g} / \mathrm{L} \mathrm{NaCl}$ and $\left.0.1 \mathrm{~g} / \mathrm{L} \mathrm{CaCl}_{2} \cdot 2 \mathrm{H}_{2} \mathrm{O}\right)$ and $8 \mathrm{~mL}$ of solution $\mathrm{B}$ (including $15 \mathrm{~g} / \mathrm{L} \mathrm{Na} \mathrm{CO}_{3}$ and $0.25 \mathrm{~g}$ Cysteine- $\mathrm{HCl}$ ) and the inoculum solution obtained was filtered through six layers of cheesecloth (Marten and Barnes, 1980). Propylene sterile syringes of $60 \mathrm{~mL}$ were used for the incubation. Twenty $\mathrm{mL}$ of inoculum solution was included in each syringe with $200 \mathrm{mg}$ of treatment (FSG0, $\mathrm{FSG}_{0.125}, \mathrm{FSG}_{0.25}, \mathrm{FSG}_{0.5}$ and $\mathrm{FSG}_{100}$ ). A total of 24 syringes were used in this trial, four syringes for each of the five treatments, as well as another four for the blanks (inoculum solution without substrate). Syringes were quickly placed in an oven and incubated at $39^{\circ} \mathrm{C}$ for $72 \mathrm{~h}$. Gas production was recorded at 1, 3, 6, 8, 12, 18, $22,30,36,42,48,54,60,66$, and $72 \mathrm{~h}$ post inoculation. At the end of incubation (72 h), $0.1 \mathrm{~mL}$ of $\mathrm{HgCl}_{2} 10 \%$ was added to each syringe to stop fermentation. After direct measurement of $\mathrm{pH}$, syringe content was transferred to $45 \mathrm{~mL}$ plastic tubes and centrifuged at $3000 \mathrm{rpm}$ for $10 \mathrm{~min}$. Supernatant was transferred in another tube and stored at $4^{\circ} \mathrm{C}$ to determine total VFA, N-NH3 and lactic acid concentration, as well as the VFA profile. Gas production values at each measurement time were corrected for gas produced at this time by the corresponding blanks. Gas production data were fitted to the monophasic model described by Groot et al. (1996): 


$$
G=\frac{A}{1+\left(\frac{B}{t}\right)^{C}}
$$

In this equation; $\mathrm{G}\left(\mathrm{mL} \mathrm{g}^{-1} \mathrm{DM}\right)$ is the amount of gas produced per gram of $\mathrm{DM}$ incubated, at time $\mathrm{t}$ after incubation; $\mathrm{A}\left(\mathrm{mL} \mathrm{g}^{-1} \mathrm{DM}\right)$ is the asymptotic gas production; B (h) is the time after incubation at which half of the asymptotic amount of gas has been formed; and $\mathrm{C}$ is the constant determining the sharpness of the switching characteristic of the profile. Maximum substrate degradation rate $\left(R_{M}\right)$ and the time after the start of the incubation at which RM occurs $\left(t_{R_{M}}\right)$ were also calculated as:

$$
t_{R_{M}}=B(C-1)^{1 / C} \quad R_{M}=\frac{\mathrm{Ct}_{R_{M}}{ }^{(C-1)}}{B^{C+t_{R_{M}}}{ }^{C}}
$$

\section{Chemical analysis}

The AOAC (2002) methods were used for DM (934.01), ash (942.05), CP (990.03, Dumas method, CN628 Elemental Analyzer, LECO, St. Joseph, MI, USA) and EE (920.39, with acid-hydrolysis of samples prior to the extraction). Starch content was determined according to Batey (1982) in a two-step enzymatic procedure with solubilisation and hydrolysis to maltodextrins with thermo-stable $\alpha$ amylase followed by complete hydrolysis with amyloglucosidase (both enzymes from Sigma-Aldrich, Steinheim, Germany), and the resulting D-glucose was measured by the hexokinase/glucose- 6 phosphate dehydrogenase/NADP system (kit D-glucose-HK Megazyme Int. Ireland Ltd, Wicklow, Ireland). The TDF content was determined by a gravimetric-enzymatic method, procedure 991.43 of Van Soest et al. (1991), with $\alpha$-amylase, protease and amyloglucosidase treatments (Megazyme TDF R.30.K-TDFR-100A/200A), correcting for ash and $\mathrm{CP}$. The NDF, ADF and lignin detergent fibre (ADL) fractions were analysed sequentially according to Mertens (2002), AOAC procedure 973.18 (2002) and Robertson and Van Soest (1981), respectively, with a thermo-stable $\alpha$-amylase pre-treatment and expressed exclusive of residual ash, using a nylon filter bag 
system (Ankom, Macedon, NY, USA). The SF content was determined as proposed by Van Soest et al. (1991), by subtracting the NDF corrected for CP from the TDF content. Determination of VFA was based on the method described by Jouany (1982). Samples were filtered through $0.45 \mu \mathrm{m}$ cellulose syringe filters. Next, $100 \mu \mathrm{L}$ of an internal standard solution $(0.4 \mathrm{~g}$ of 4 -methylvaleric acid diluted in $100 \mathrm{~mL}$ of deionised water) and $0.1 \mathrm{~mL}$ of a preservative $\left(5 \% \mathrm{H}_{3} \mathrm{PO}_{4}\right.$ and $1 \% \mathrm{HgCl}_{2}$ in deionised water) were added to $0.9 \mathrm{~mL}$ of filtrate. One $\mu \mathrm{L}$ from each sample was injected into a gas chromatograph (Fisons 8000 series, Milan, Italy) equipped with a split/split less injector and FID detector. The separation of VFA was done in a DB-FFAP capillary column (30 $\mathrm{m} \times 0.25 \mathrm{~mm} \times 0.25 \mu \mathrm{m}$ of film thickness, J\&W Scientific, Folson, CA, USA). The carrier gas was $\mathrm{N}_{2}$ at a constant pressure of $120 \mathrm{kPa}$. Injector and detector temperatures were set at $200{ }^{\circ} \mathrm{C}$ and $245^{\circ} \mathrm{C}$ respectively. The initial oven temperature was set at $110^{\circ} \mathrm{C}$ held for $5 \mathrm{~min}$ and increased to $230^{\circ} \mathrm{C}$ at $8.5^{\circ} \mathrm{C} / \mathrm{min}$ and finally maintained at that temperature for $10 \mathrm{~min}$. Finally, VFA were identified by comparing their retention times with a standard (46975-U from Supelco ${ }^{\circledR}$, Bellefonte, PA, USA). N-NH3 concentration was determined using the nesslerisation spectrophotometric method adapted of Koroleff (1966). The VFA and $\mathrm{N}-\mathrm{NH}_{3}$ concentrations were expressed as mmol/L of the liquid phase of caecal digesta. Lactic acid was determined according to the method of Borshchevskaya et al. (2016), where an aliquot of the samples was diluted 20 times with deionised water, $50 \mu \mathrm{L}$ from the dilution was added to 2 $\mathrm{mL}$ of a $0.2 \%$ solution of $\mathrm{FeCl}_{3}$, the mixture was stirred and absorbance was measured at $390 \mathrm{~nm}$ against a reference solution $\left(2 \mathrm{~mL}\right.$ of a $\left.0.2 \% \mathrm{FeCl}_{3}\right)$. Colour solution was stable for $15 \mathrm{~min}$. All in vitro traits values were corrected by their corresponding blanks.

\section{Statistical analysis}

All the traits in this work were statistically analysed with a General Linear Model (GLM) procedure from SAS (2009). For the digestibility traits, the model included 
the effect of FSG inclusion (0, 0.25 and $0.5 \%)$, the age (38 and $56 \mathrm{~d}$ ) and their interaction as main effects. However, for the caecal environment and in vitro traits, the model only included the effect of FSG inclusion $(0,0.25$ and $0.5 \%$, or 0 , $0.125,0.25$ and $0.5 \%$, respectively) as main effect. An orthogonal contrast to evaluate the effect of FSG inclusion $\left[\mathrm{FSG}_{0}-\left(\mathrm{FSG}_{0.25}+\mathrm{FSG}_{0.5}\right) / 2\right.$ ] was performed for digestibility and caecal traits, while possible linear effect of FSG inclusion (from 0 to $0.5 \%$ ) was evaluated for the in vitro traits.

\section{Results}

All animals were perfectly adapted to the experimental diets and no morbidity or mortality problems were recorded throughout the growing period. No significant differences were observed for the final body weights at 94 days of age, which were $2360 \pm 32,2428 \pm 32$ and $2376 \pm 32 \mathrm{~g}$ for $\mathrm{FSG}_{0}, \mathrm{FSG}_{0.25}$ and $\mathrm{FSG}_{0.5}$ respectively. During the digestibility trial, daily feed intake obviously increased with the age of the growing rabbits $(+28 \%$ from 38 to 56 days; $\mathrm{P}<0.001)$ but was not affected by the inclusion level of FSG in the diet (Table 1.2).

Table 1.2. Effect of the dietary inclusion of fenugreek seed gum (FSG) and the age of growing rabbits on feed intake ( $\mathrm{g}$ dry matter/d) and in vivo apparent digestibility coefficients of nutrients.

\begin{tabular}{lcccccccccccc}
\hline & \multicolumn{4}{c}{ FSG level (\%) } & \multicolumn{4}{c}{ Age (d) } & \multicolumn{3}{c}{ P-Value } \\
\cline { 2 - 11 } & FSG0 & FSG0.25 & FSG0.5 & SEM & 38 & 56 & SEM & FSG & Age & FSG×Age \\
\hline Feed intake & 105 & 102 & 103 & 1.50 & 91 & 116 & 1.20 & 0.349 & 0.001 & 0.279 \\
Digestibility coefficients: & & & & & & & & & & & \\
Dry matter & 0.527 & 0.538 & 0.526 & 0.007 & 0.520 & 0.541 & 0.007 & 0.430 & 0.051 & 0.517 \\
Organic matter & 0.528 & 0.542 & 0.526 & 0.007 & 0.524 & 0.539 & 0.006 & 0.269 & 0.129 & 0.512 \\
Crude protein & 0.634 & 0.658 & 0.647 & 0.010 & 0.649 & 0.644 & 0.009 & 0.262 & 0.655 & 0.262 \\
Neutral detergent fibre & 0.209 & 0.224 & 0.234 & 0.010 & 0.198 & 0.247 & 0.010 & 0.239 & 0.006 & 0.751 \\
Acid detergent fibre & 0.057 & 0.062 & 0.083 & 0.012 & 0.043 & 0.091 & 0.011 & 0.273 & 0.017 & 0.827 \\
Ether extract & 0.859 & 0.859 & 0.859 & - & 0.865 & 0.853 & - & - & - & - \\
Total dietary fibre & 0.252 & 0.270 & 0.267 & - & 0.250 & 0.276 & - & - & - & - \\
Soluble fibre & 0.534 & 0.574 & 0.559 & - & 0.568 & 0.543 & - & - & - & - \\
\hline
\end{tabular}

SEM: standard error of the means. 
Apparent faecal digestibility coefficients (d) of main nutrients were not significantly affected by the dietary inclusion of FSG. However, dNDF and dADF at $56 \mathrm{~d}$ were significantly higher than that observed at $38 \mathrm{~d}$ of age $(+0.049$ and +0.048 percentage points, respectively; $\mathrm{P}<0.05)$, which could explain the higher $\mathrm{dDM}$ with the age observed $(+0.021 ; \mathrm{P}=0.051)$. No significant interaction was observed between the inclusion of FSG and age during the digestibility trial. The effect of dietary inclusion of FSG on the caecal traits is presented in Table 1.3.

Table 1.3. Effect of fenugreek seed gum (FSG) dietary inclusion on caecal $\mathrm{pH}$, total volatile fatty acids production (VFA), VFA profile, lactic acid and the ammonia $\mathrm{N}$ in growing rabbits.

\begin{tabular}{lccccc}
\hline \multicolumn{5}{c}{ FSG level (\%) } \\
\hline & FSG & FSG0.25 & FSG0.5 & SEM & P-value \\
\hline Caecal pH* & 5.82 & 5.69 & 5.65 & 0.0581 & 0.096 \\
Caecal VFA (mmol/L) & 50.8 & 46.6 & 50.01 & 2.77 & 0.534 \\
VFA profile (\% of total VFA): & & & & & \\
$\quad$ Acetic acid & 75.9 & 76.2 & 76.3 & 0.944 & 0.915 \\
Butyric acid & 12.5 & 12.7 & 13.0 & 0.639 & 0.868 \\
Propionic acid & 7.96 & 7.01 & 6.79 & 0.538 & 0.264 \\
Isobutyric acid & 0.350 & 0.423 & 0.339 & 0.0544 & 0.519 \\
Valeric acid & 1.54 & 1.40 & 1.34 & 0.109 & 0.428 \\
Isovaleric acid & 0.853 & 0.957 & 0.823 & 0.104 & 0.649 \\
Caproic acid* & 0.790 & 1.25 & 1.29 & 0.231 & 0.234 \\
Heptanoic acid & 0.0436 & 0.0637 & 0.0743 & 0.0143 & 0.304 \\
Lactic acid (mmol/L) & 0.0589 & 0.0636 & 0.0578 & 0.00503 & 0.690 \\
Propinic/butyric ratio & 0.637 & 0.529 & 0.591 & 0.0495 & 0.375 \\
Caecal N-NH $(\mathrm{mmol} / \mathrm{L})$ & 5.70 & 5.43 & 5.71 & 0.192 & 0.528 \\
\hline
\end{tabular}

SEM: standard error of the means; ${ }^{*}$ Contrast FSG0 - [FSG0.25+FSG0.5]/2: Caecal pH $(\mathrm{P}=0.037)$ and caproic $\operatorname{acid}(\mathrm{P}=0.093)$.

No significant effect of the dietary inclusion of FSG on any of the traits related to the caecal environment was observed. However, animals fed with FSG showed lower caecal $\mathrm{pH}(-0.15 ; \mathrm{P}=0.037)$ and slightly higher caproic acid concentration in the caecum $(+0.48 \%$; $=0.093)$ than those fed with FSo. Table 1.4 shows the effect of dietary inclusion of FSG on the gas production parameters estimated throughout incubation and the in vitro traits controlled at the end of this incubation. 
Table 1.4. Effect of fenugreek seed gum (FSG) dietary inclusion in rabbit diets and pure FSG on the gas production parameters of monophasic model [Groot et al., 1996; $\mathrm{G}_{\mathrm{t}}=$ $\mathrm{A} /(1+(\mathrm{B} / \mathrm{t}) \cdot \mathrm{C})]^{1}$ and some in vitro traits after incubation.

\begin{tabular}{|c|c|c|c|c|c|c|c|}
\hline \multicolumn{8}{|c|}{ FSG level (\%) } \\
\hline & $\mathrm{FSG}_{0}$ & FSG 0.125 & $\mathrm{FSG}_{0.25}$ & $\mathrm{FSG}_{0.5}$ & FSG 100 & SEM & P-value \\
\hline \multicolumn{8}{|l|}{ Gas kinetic parameters: } \\
\hline $\mathrm{A}(\mathrm{mL} / \mathrm{g} \mathrm{DM})$ & $12.3^{\mathrm{a}}$ & $11.9^{a}$ & $11.6^{\mathrm{a}}$ & $11.7^{\mathrm{a}}$ & $23.1^{\mathrm{b}}$ & 0.72 & $<0.001$ \\
\hline $\mathrm{B}(\mathrm{h})$ & $15.3^{\mathrm{b}}$ & $15.5^{\mathrm{b}}$ & $14.6^{\mathrm{b}}$ & $15.8^{\mathrm{b}}$ & $9.44^{\mathrm{a}}$ & 0.72 & $<0.001$ \\
\hline $\mathrm{C}$ & $2.28^{a}$ & $2.24^{\mathrm{a}}$ & $2.28^{a}$ & $2.29 a$ & $4.25^{\mathrm{b}}$ & 0.07 & $<0.001$ \\
\hline$t_{\mathrm{R}_{\mathrm{M}}}(\mathrm{h})^{317}$ & $17.0^{\mathrm{b}}$ & $17.1^{\mathrm{b}}$ & $16.2^{\mathrm{b}}$ & $17.6^{\mathrm{b}}$ & $12.5^{\mathrm{a}}$ & 0.94 & 0.010 \\
\hline $\mathrm{RM}_{\mathrm{M}}\left(\mathrm{h}^{-1}\right)^{2}$ & $0.07 \mathrm{a}$ & $0.07^{a}$ & $0.08^{\mathrm{a}}$ & $0.07^{a}$ & $0.26^{\mathrm{b}}$ & 0.01 & $<0.001$ \\
\hline \multicolumn{8}{|l|}{ In vitro traits $4:$} \\
\hline$\Delta \mathrm{pH}$ & $-0.52^{\mathrm{b}}$ & $-0.49 \mathrm{~b}$ & $-0.49^{b}$ & $-0.48^{\mathrm{b}}$ & $-1.53^{a}$ & 0.026 & $<0.001$ \\
\hline$\Delta \operatorname{VFA}(\mathrm{mmol} / \mathrm{L})^{6}$ & $56.7^{a}$ & $46.7^{\mathrm{a}}$ & $75.9 \mathrm{ab}$ & $106.9 \mathrm{~b}$ & $114.7 \mathrm{~b}$ & 17.7 & $<0.001$ \\
\hline$\Delta$ Lactic acid $(\mathrm{mmol} / \mathrm{L})^{6}$ & $14.0^{\mathrm{b}}$ & $9.73^{b}$ & $5.89^{\mathrm{ab}}$ & $6.64^{\mathrm{ab}}$ & $-0.43^{a}$ & 3.23 & 0.069 \\
\hline$\Delta \mathrm{N}-\mathrm{NH}_{3}(\mathrm{mmol} / \mathrm{L})$ & $2.91^{\mathrm{b}}$ & $2.96^{\mathrm{b}}$ & $2.76^{\mathrm{b}}$ & $2.76^{\mathrm{b}}$ & $-9.96^{\mathrm{a}}$ & 0.362 & $<0.001$ \\
\hline
\end{tabular}

${ }^{1} \mathrm{Gt}(\mathrm{mL} / \mathrm{g} \mathrm{DM})$, amount of gas produced per gram of DM at time of incubation, A (mL/g DM), asymptotic gas production; B (h), time to achieve half of the asymptotic amount of gas; $\mathrm{C}$, constant determining the sharpness of the switching characteristic of the profile.

${ }^{2}$ RM: maximum substrate degradation at time $t_{\mathrm{R}_{\mathrm{M}}}$.

${ }^{3} t_{\mathrm{R}_{M}}$ : time after the start of the incubation at which RM occurs.

${ }^{4}$ Change respect to the blank (caecal inoculum without treatment).

5 Total volatile fatty acids.

${ }^{6}$ Lineal effect of FSG dietary inclusion: VFA $(\mathrm{P}=0.038)$ and lactic acid $(\mathrm{P}=0.091)$.

a.b Means in a row not sharing the same letter are significantly different at $\mathrm{P}<0.05$.

In comparison to the experimental diets, pure FSG (FSG 100$)$ significantly affected the main gas kinetic parameters (Figure 1.1), increasing $A, C$ and $R_{M}$ traits, but decreasing $B$ and $t_{\mathrm{R}_{\mathrm{M}}}$ traits $(\mathrm{P}<0.001)$. However, gradual dietary inclusion of FSG (from 0 to $0.5 \%$ ) had no effect on any of these kinetic parameters (Figure 1.2). Similarly, FSG100 significantly decreased caecal $\mathrm{pH}$, total VFA production, as well as lactic acid and $\mathrm{N}-\mathrm{NH}_{3}$ concentrations compared to the values observed with the experimental diets $(\mathrm{P}<0.001)$. Finally, gradual dietary inclusion of FSG from 0 to $0.5 \%$ significantly increased total VFA production $(+100 \mathrm{mmol} / \mathrm{L}$ per percentage point of FSG inclusion; $\mathrm{P}=0.038$ ) and slightly decreased lactic acid concentration in the caecum $(-14 \mathrm{mmol} / \mathrm{L}$ per percentage point of FSG inclusion; $\mathrm{P}=0.091)$. 
(a)

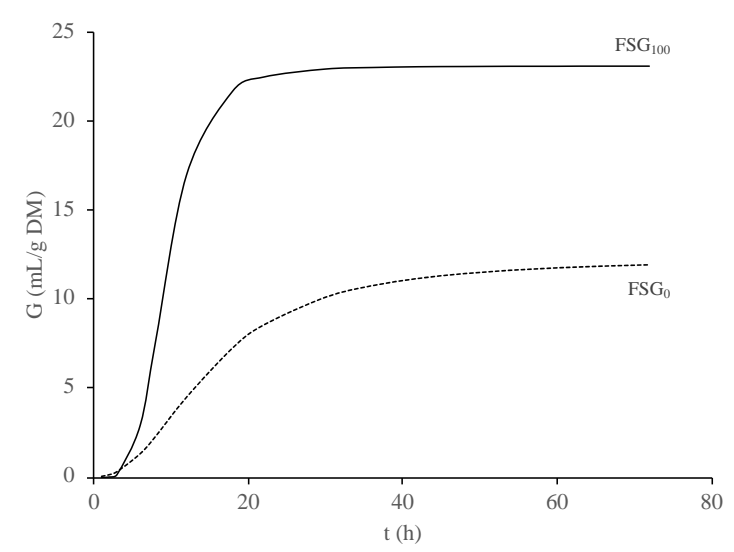

(b)

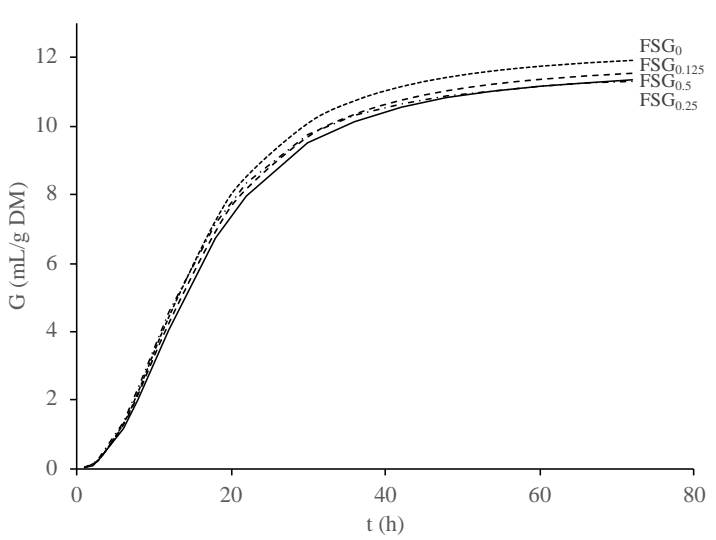

Figure 1.1 Evolution of gas production during the in vitro incubation of the fenugreek seed gum (FSG) and the experimental diets with caecal inocula: (a) Comparison of FSG pure (FSG100) with the basal diet (FSG); (b) Comparison of the four experimental diets including $0,0.125,0.25$ and $0.5 \%$ of FSG (FSG0, FSG 0.125, FSG $_{0.25}$ and FSG 0.5 , respectively). Curves fitted to the monophasic model of Groot et al., $1996\left[\mathrm{G}_{\mathrm{t}}=\mathrm{A} /(1+(\mathrm{B} / \mathrm{t}) \cdot \mathrm{C})\right]$. For coefficients description see Table 1.4.

\section{Discussion}

The results of this work show that FSG inclusion in diet up to $0.5 \%$ does not produce any significant effect on the apparent faecal digestibility of DM or its main components. However, we did observe that the values obtained for the digestibility of all fibrous fractions (TDF, SF, NDF and ADF) were always between 2 and 3\% higher when the diets included FSG. Although galactomannan is not expected to affect the digestibility of the dietary components that are mainly digested in the small intestine, it could be expected that high fermentability of galactomannans in the caecum could promote the fibrolytic microbiota of the caecum, having an effect on the use of the rest of the fibrous fractions.

In fact, Trocino et al. (2013b), in a meta-study on soluble fibre in rabbits, showed that an increase in dietary SF is positively correlated with an improvement of the digestibility of the remaining fibrous fractions. However, contrary to expectations, other studies have observed a lower cellulose digestibility in rabbits 
(Volek et al., 2007) and pigs (Lipinski et al., 2005) when mannan-oligosaccharides were included in the diet. On the other hand, although the faecal digestibility of NDF and ADF increased with the age of growing rabbits, no interaction with FSG inclusion was observed. Increasing digestive efficacy with age is a well-known effect. Evans and Jebelian (1982) observed that the digestibility of ADF increased by 0.95 percentage points per week between 5 and 12 weeks of age. Moreover, comparing nutrient digestibility of growing rabbits and rabbit females (Read et al., 2017), digestibility of NDF and ADF was higher in rabbit females due to the higher digestive capacity of adult animals.

Most of the water-soluble polysaccharides and oligosaccharides are not digested in the small intestine but are rapidly fermented in the hindgut (Volek and Marounek, 2011). In our work, we observed that the dietary inclusion of FSG up to $0.5 \%$ did not lead to major significant changes in the caecal environment of growing rabbits at $94 \mathrm{~d}$ of age. The only changes observed were a slight reduction in the caecal $\mathrm{pH}$ and a non-significant increase in some VFA, especially caproic acid. Some previous studies have observed that a reduction in caecal $\mathrm{pH}$ could inhibit the growth of some pathogenic bacteria, such as E. coli in rabbits (Gidenne and Licois, 2005), and an increase in the concentration of caproic acid in the caecum could also help to reduce the count of E. coli and C. perfringens (Skrivanova et al., 2006; 2008). For that reason, it would be interesting to continue exploring the possible effect of FSG on the caecal environment with a greater inclusion in the diet, as inclusion up to $0.5 \%$ has not been able to produce relevant changes. In vitro gas production can reflect the extent to which substrates are fermented by gut microorganisms (Schofield, 2000). Water-soluble fibres, like the galactomannan of FSG, seem to be highly fermentable in the rabbit caecum, leading to high gas production, the production of a greater amount of VFA and reduction of the $\mathrm{N}_{-} \mathrm{NH}_{3}$ free at the final inoculum. Compared to the rabbit diets used in this work (Figure 1.1), kinetic traits obtained for the pure FSG were 
characterised by higher substrate degradation rate, lower time to achieve the maximum rate of degradation and clearly higher asymptotic gas production, which confirms the potential of FSG to be used by the fibrolytic microbiota of the rabbit's caecum. Recently, Ocasio-Vega et al. (2018) compared gas production kinetics and in vitro traits of different fibrous substrates (cellobiose, pectin, sugar beet pulp and wheat bran). When compared to a high insoluble fibre (wheat straw), the other fibrous substrates lead to a higher gas production after in vitro incubation with a rabbit caecal inoculum, and the higher the SF content, the higher the gas production. Similar results were observed by Abad-Guamán et al. (2018) when comparing gas production of different substrates (pectin, sugar beet pulp and wheat straw) in a caecal inoculum for $28 \mathrm{~h}$, where the volume of gas was proportional to the amount of substrate fermented. The higher microbial activity associated with the increased availability of a fermentable substrate is also usually associated with promoted microbial protein synthesis and reduced $\mathrm{N}-\mathrm{NH}_{3}$ level in the caecum (Carabaño et al., 2009; Trocino et al., 2013a). However, dietary inclusion of FSG up to $0.5 \%$ did not affect any of the kinetic parameters of the gas production model (Figure 1.2). Bovera et al. (2010), comparing in vitro gas production of rabbit diets including mannan-oligosaccharides (MOS) up to $0.15 \%$ or supplemented with antibiotics, observed higher gas production and fermentation rate of MOS diets compared to the diet with antibiotics when gas production was fitted to the same model used in the present work (Groot et al., 1996). However, a lineal increase in MOS inclusion from 0.05 to $0.15 \%$ did not affect gas production, although it seems to increase $R_{M}$ and to reduce $t_{R_{M}}$. These results seem to indicate that the inclusion of low levels of fermentable substrates does not excessively affect in vitro gas production. The lack of differences in the kinetics traits observed with the inclusion of FSG may be due to a higher dilution of the inoculum in this work (2:1 and 4:1 in Bovera et al. (2010) and this work, respectively). In any case, dietary inclusion of FSG up to $0.5 \%$ caused a linear increase in the observed increase in the VFA content of the caecum during in vitro 
fermentation, due to its high fermentability, but without any relevant effect on the VFA profile.

\section{Conclusion}

It can be concluded that pure FSG is highly and rapidly fermented in the rabbit caecum, decreasing the $\mathrm{pH}$ and $\mathrm{N}-\mathrm{NH}_{3}$ concentration and increasing total VFA level when it was in vitro incubated in a caecal inoculum. However, dietary inclusion of FSG up to $0.5 \%$, although it linearly increased the total VFA level after in vitro incubation and decreased the caecal $\mathrm{pH}$ of young rabbits, did not affect the apparent digestibility and fermentation profile of the animals to any great extent. Based on these results, it would be convenient to carry out more studies on the fermentation pattern of this galactomannan, and on how its greater inclusion can affect growth performance, digestive health and microbiota in growing rabbits.

\section{Acknowledgements}

This study is supported by the Interministerial Commission for Science and Technology (CICYT) of the Spanish Government (AGL2017-85162-C2-1R), the Universitat Politècnica de València (Project 20180290; Spain), and the Higher School of Agriculture of Mateur of the Carthage University (Tunisia Republic). Grant for Jihed Zemzmi from the Carthage University is also gratefully acknowledged.

\section{References}

Abad-Guamán R, Larrea-Dávalos J. A, Carabaño R, García J, Carro M. D. 2018. Influence of inoculum type (ileal, caecal and faecal) on the in vitro fermentation of different sources of carbohydrates in rabbits. World Rabbit Science, 26, 227-240.

AOAC. 2002. Official methods of analysis of the AOAC International. 17th ed. AOAC International, Gaithersburg, MD USA. 
Bartley G. B, Hiltry M.D, Andreson B.D, Clairemont A.C, Maschke S.P. 1981. “Maplesyrup" urine odor due to fenugreek ingestion. The New England Journal of Medicine, 305, 467.

Batey I. L. 1982. Starch Analysis Using Thermostable Alpha-Amylases. Starch/Stärke, 34, 125-128.

Boletín Oficial del Estado. 2013. Real Decreto 53/2013, por el que se establecen las normas básicas aplicables para la protección de los animales utilizados en experimentación y otros fines científicos, incluyendo la docencia. BOE, 34, 11370-11421.

Bónai A, Szendrő Zs, Matics Zs, Fébel H, Kametler L, Tornyos G, Horn P, Kovács F, Kovács M. 2010. Effect of inulin supplementation and age on growth performance and digestive physiological parameters in weaned rabbits. World Rabbit Science, 18, 121-129.

Borshchevskaya L. N, Gordeeya T. L, Kalinina A. N, and Sineokii S. P. 2016. Spectrophotometric determination of lactic acid. Journal of. Anal. Chem, 71, 755.

Bovera F, Marono S, Di Meo C, Piccolo G, Iannaccone F, Nizza A. 2010. Effect of mannanoligosaccharides supplementation on caecal microbial activity of rabbits. Animal, 4, 1522-1527.

Jouany J. P. 1982. Volatile Fatty Acid and Alcohol Determination in Digestive Contents, Silage Juices, Bacterial Cultures and Anaerobic Fermentor Contents. Sciences des Aliments, 2, 131-144.

Korman S. H, Cohen E, Preminger A. 2001. Pseudo-maple syrup urine disease due to maternal prenatal ingestion of fenugreek. Journal of Pediatrics and Child Health, 37, 403404.

Koroleff F. 1966. Direct spectrophotometric determination of ammonia in precipitation. Tellus XVIII, 2.

Lipinski K, Purwin C, Tywonczuk J, Zdunczyk Z, Wroblewska M, LaniewskaTrokenheim L, Warminska-Radyko L. 2005. Effects of feed additives on nutrient digestibility and the bacterial status of faeces in pigs. Journal of Animal and Feed Science, 14, 369-372.

Majeed M, Majeed S, Nagabhushanam K, Arumugam S, Natarajan S, Beede K, Furqan A. 2018. Galactomannan from Trigonella foenum-graecum L. Seed, Prebiotic application and its fermentation by prebiotic Bacillus coagulans strain MTCC 5856. Food Science Nutrition, 6, 666-673. 
Marten G. C, Barnes R. F. 1980. Prediction of energy digestibility of forages with in vitro rumen fermentation and fungal enzyme systems. In, W.J. Pigden, C.C. Balch, M. Graham (Eds.), In Proc., The International Workshop on Standardization of Analytical Methodology for Feeds, Int. Dev. Res. Center, Ottawa, Ont, Canada. 61-71.

Martínez-Vallespín B, Martínez-Paredes E, Ródenas L, Cervera C, Pascual J.J, Blas E. 2011. Combined feeding of rabbit female and young, Partial replacement of starch with acid detergent fibre or/and neutral detergent soluble fibre at two protein levels. Livestock Science, 141, 155-165.

Martínez-Vallespín B, Martínez-Paredes B, Ródenas L, Moya J.M, Cervera C, Pascual J.J, Blas E. 2013. Partial replacement of starch with acid detergent fibre and/or neutral detergent soluble fibre at two protein levels, Effects on ileal apparent digestibility and caecal environment of growing rabbits. Livestock Science, 154, 123-130.

Mazza G, Di Tommaso D, Foti S. 2002. Volatile constituents of Sicilian fenugreek (Trigonella foenum-graceum L.) seeds. Sciences des Aliments, 22, 249-264.

Mertens D. R. 2002. Gravimetric determination of amylase-treated neutral detergent fibre in feeds with refluxing in beakers or crucibles, Collaborative study. J. AOAC Int, 85, 1217-1240.

Naidu M. M, Shyamala B. N, Naik J. P, Sulochanamma G, HRinivas P. 2011. Chemical composition and antioxidant activity of the husk and endosperm of fenugreek seeds. LWT-Food Science and technology, 44, 451-456.

Ocasio-Vega C, Abad-Guamán R, Delgado R, Carabaño R, Dolores Carro M, Javier García. 2018. Effect of cellobiose supplementation and dietary soluble fibre content on in vitro caecal fermentation of carbohydrate-rich substrates in rabbits. Archives of Animal Nutrition, 1477-2817.

Perez J. M, Lebas F, Gidenne T, Maertens L, Xiccato G, Parigi-Bini R, Dalle Zotte A, Cossu M.E, Carazzolo A, Villamide M. J, Carabaño R, Fraga M. J, Ramos M. A, Cervera C, Blas E, Fernández J, Cunha L. F. E, Freire J. B. 1995. European reference method for in vivo determination of diet digestibility in rabbits. World Rabbit Science, 3, 41-43.

Read T, Gidenne T, Combes S, Labatut D, Bricard D, Bébin K, Fortun-Lamothe L. 2017. Digestibilité comparée chez le lapin, effets de l'âge, de l'état et du stade physiologiques. In : Proceedings of the 17ème Journées de la Recherche Cunicole, 21-22 Novembre, 2017. Le Mans, France. 117-180. 
Robertson J. B, Van Soest P. J, James W. P. T, Theander O. 1981. The analysis of dietary fibre in food. The detergent system of analysis and its application to human foods. James, WPT and Theander, O, eds. Marcel Dekker, New York, NY, 123-158.

Rosell J. M, de la Fuente L. F, Badiola J. I, Fernández de Luco D, Casal J, Saco M. 2009. Study of urgent visits to commercial rabbit farms in Spain and Portugal during 19972007. World Rabbit Science, 17, 127 -136.

SAS. 2009. SAS/STAT User's Guide (Release 9.2). SAS Institute. Inc, Cary NC, USA.

Schofield P. 2000. Gas production methods. Farm Animal Metabolism and Nutrition. J. P. F. D'Mello, ed. CAB International, Wallingford, Oxon, U.K. 209-232.

Sewell A. C, Mosandl A, Bohles H. 1999. False diagnosis of maple syrup urine disease owing to ingestion of herbal tea. Massachusetts Medical Society, 341, 769.

Skrivanova E, Marounek M, Benda V, Brezina P. 2006. Susceptibility of Escherichia coli, Salmonella sp. and Clostridium perfringens to organic acids and monolaurin. Veterinarni Medicina, 51, 81-88.

Skrivanova E, Molatova Z, Marounek M. 2008. Effects of caprylic acid and triacylglycerols of both caprylic and capric acid in rabbits experimentally infected with enteropathogenic Escherichia coli O. Veterinary Microbiology, 126, 372-376.

Trocino A, Fragkiadakis M, Majolini D, Tazzoli M, Radaelli G, Xiccato G. 2013a. Soluble fibre, starch and protein level in diets for growing rabbits, Effects on digestive efficiency and productive traits. Animal Feed Science and Technology, 180, 73-82.

Trocino A, García J, Carabaño R, Xiccato G. 2013b. A meta-analysis of the role of soluble fibre in diets for growing rabbits. World Rabbit Science, 21, 1-15.

Van Soest P. J, Robertson J. B, Lewis B. A. 1991. Methods for dietary fibre, neutral detergent fibre, and non-starch polysaccharides in relation to animal nutrition. Journal of Dairy Science, 74, 3583-3597.

Volek Z, Marounek M, Skrivanova V. 2007. Effect of a starter diet supplementation with mannan-oligosaccharide or inulin on health status, caecal metabolism, digestibility of nutrients and growth of early weaned rabbits. Animal, 1, 523-530.

Volek Z, Marounek M. 2011. Dried chicory root (cichorium intybus l.) as a natural fructan source in rabbit diet, effects on growth performance, digestion and caecal and carcass traits. World Rabbit Science, 19, 143-150. 
Zemzmi J, Mabrouki S, Abdouli H, Najar T. 2017. Preliminary characterization of fenugreek seed gum for use as prebiotic in rabbits' nutrition. In: Proceedings of the 20th International Symposium on Housing and Diseases of Rabbits, Fur Providing Animals and Pet Animals, 17-18 May 2017, Celle, Germany, pp. 179-186. 


\section{Chapter II}

Characterisation and in vitro evaluation of fenugreek (Trigonella foenumgraecum) seed gum as a potential prebiotic in growing rabbit nutrition.

Jihed Zemzmi 1,2,3, Luis Ródenas ${ }^{2}$, Enrique Blas ${ }^{2}$, Taha Najar ${ }^{1,3}$, Juan José Pascual $^{2}$

${ }^{1}$ Materials, Molecules and Applications Laboratory, Preparatory Institute for Scientific and Technical Studies, University of Carthage, BP51, La Marsa 2070, Tunisia

2 Institute for Animal Science and Technology, Universitat Politècnica de València, Camino de Vera, s/n, 46022 Valencia, Spain

${ }^{3}$ Department of Animal Production, National Agronomic Institute of Tunisia, University of Carthage, 43 Avenue Charles Nicolle, Mahrajène 1082, Tunisia 


\section{Abstract}

Some components of soluble fibre appear to have prebiotic effects that can contribute to improving digestive health in post-weaning rabbits. In this work, a fenugreek seed gum (FSG), extracted from Trigonella foenum-graecum seeds and rich in galactomannan, was characterised. Both the pure FSG and ten substrates obtained by the inclusion of $0,5,10,15$ and $20 \mathrm{~g} / \mathrm{kg}$ of FSG in diets rich in soluble (SF) and insoluble (IF) fibre were evaluated in vitro to determine FSG prebiotic potential for rabbit diets. FSG was rich in total sugars (630 g/kg dry matter), consisting entirely of galactose and mannose in a 1,1 ratio, and a moderate protein content ( $223 \mathrm{~g} / \mathrm{kg}$ dry matter). Pure FSG was affected very little by in vitro digestion, as only $145 \mathrm{~g} / \mathrm{kg}$ of the FSG was dissolved during the enzymatic phase. However, the linear inclusion of FSG up to $20 \mathrm{~g} / \mathrm{kg}$ in growing rabbit feeds has led to a reduction in the solubility of some nutrients during in vitro enzymatic phase, especially in SF diets. Pure FSG not digested during the enzymatic phase almost completely disappeared during the in vitro fermentation phase, $984 \mathrm{~g} / \mathrm{kg}$ of this indigestible fraction. However, although linear inclusion of FSG up to 20 $\mathrm{g} / \mathrm{kg}$ in SF diets increased the fermented fraction, no relevant changes in the fermentation profile were observed. In conclusion, FSG satisfies two essential conditions of the prebiotic effect, showing resistance to in vitro enzymatic digestion and being totally fermented in vitro by caecal bacteria, although in vivo studies will be necessary to determine its prebiotic potential.

Keywords, fenugreek seed, galactomannan, rabbit, digestion in vitro, prebiotic

\section{Introduction}

Digestive disorders are the main cause of post-weaning mortality and veterinary visits in rabbit farms, and epizootic rabbit enteropathy (ERE) remains the major cause of these losses (Coudert et al., 1997; Rosell et al., 2009). The solution to these digestive disorders must come through control of causative microorganisms. 
However, we know that diet seems to be a risk factor, mainly due to its ability to modulate the microbiota (Gidenne et al., 2010). It is well known that a deficit in fibre or an excess of protein increase the risk of digestive disorders (Gidenne et al., 2001; Carabaño et al., 2009), and that the level and nature of the fibre can also affect the digestive health of weaned rabbits, thus a minimum level of both insoluble and soluble fractions of fibre are required to reduce the digestive risk (Gidenne et al., 2001). However, even when designing diets under the recommended standards, the need to use antimicrobials after weaning as a consequence of these digestive disorders is very frequent. Some of the substances that constitute the soluble fibre affect the digestive utilisation of soluble and insoluble fibre fractions, and their dietary inclusion is usually associated with reduced mortality in growing rabbits affected by epizootic rabbit enteropathy (Trocino et al., 2013a). Furthermore, Falcão-e-Cunha et al. (2007) reported that some prebiotics, which are normally part of the soluble fibre of some plants, could be alternatives to antibiotics in young rabbit nutrition. Some fructooligosaccharides, galactooligosaccharides and mannooligosaccharides have been tested on rabbits with inconsistent results as regards mortality, growth performance and feed conversion ratio (Peeters et al., 1992; Gidenne et al., 1995; Aguilar et al., 1996; Lebas, 1996; Mourão et al., 2004). However, these prebiotics seem to have the capacity to improve the barrier effect against pathogens, promoting recovery of the intestinal mucosa, increasing the production of total volatile fatty acids (VFA) and reducing the ammonia content in the rabbit caecum (Morisse et al., 1992; Maertens et al., 2004; Mourão et al., 2006). Among these members of the soluble fibre group there is a non-starch polysaccharide known as galactomannan, composed of a (1-4)-linked beta d-mannopyranose backbone with branch points from their 6-positions linked to alpha-d-galactose (Jiang et al., 2007). Galactomannan has been reported as a potential prebiotic for starting broilers when used with the appropriate exogenous enzymes (Kakani, 2013) and seems to contribute to increased serum antibody against Newcastle disease virus 
in this species (Wang et al., 2003). In pigs, 10\% of dietary carob tree seeds as a source of locust bean gum, rich in galactomannans, enhanced intestinal characteristics at the bacteriological and morphological level (Van Nevel et al., 2005). The main commercial sources of galactomannans are guar gum (Cyamopsistetragonolobo, with a mannose/galactose ratio 2,1), tara gum (Caesalpiniaspinosa, 3,1) and locust bean gum (Ceratoniasiliqua, 3.5,1) (Dakia et al., 2008). However, another unconventional source of galactomannan that could be found in Mediterranean countries is Trigonella foenum-graecum, known as fenugreek. Although there is no information on the use of galactomannans of this origin in animals, they have exhibited prebiotic activity in in vitro models, as well as suitability with probiotics in a symbiotic combination (Majeed et al., 2018). These results could indicate that galactomannan from fenugreek seeds could be a good candidate as a prebiotic in rabbits. Therefore, the aim of this study initially was to characterise the fenugreek seed gum (FGS) obtained by extraction, and then determine whether this extract maybe a potential prebiotic in rabbit diets enriched with soluble or insoluble fibre, through an in vitro model of an initial enzymatic digestion and subsequent fermentation with rabbit caecal inoculum.

\section{Materials and Methods}

Animal housing, husbandry and slaughtering conditions followed the current recommendations on principles of ethical care and protection of animals used for experimental purposes in the European Union (2010) and all trials were subjected to approval by the Animal Protocol Review Committee of the Polytechnic University of Valencia (research code, 2018/VSC/PEA/0116). The experiment was also carried out following the recommendations for applied nutrition research in rabbits described by the European Group on Rabbit Nutrition (FernándezCarmona et al., 2005). 


\section{Fenugreek Seed Gum Characterisation}

Fenugreek seeds were bought from the weekly market of the Mateur region in the North of Tunisia. As described in Reference (Zemzmi et al., 2017), from a batch of ground fenugreek seeds, three subsamples (200 g each) were used for gum extraction. Each extraction consisted of twice defatting in $200 \mathrm{~mL}$ hexaneisopropanol $(3 / 2, v / v)$, washing with $150 \mathrm{~mL}$ acetone, solubilising in $2 \mathrm{~L}$ of distilled water for $24 \mathrm{~h}$, precipitating with ethanol (1L), freeze-drying and grinding to pass $1 \mathrm{~mm}$ diameter. For an initial characterisation, chemical composition, the physical properties and fermentation pattern of the FSG obtained were determined. Regarding its chemical composition, the FSG was subjected to a preliminary qualitative phytochemical screening test for the detection of steroids, terpenoids, flavonoids, tannins, alkaloids, coumarins, saponins, free amino acids and reducing sugar in its composition. Moreover, the FSG was analysed to determine the content in dry matter (DM), ashes, crude protein $(\mathrm{CP})$, total sugars, sugars composition and amino acid composition. Neutral detergent fibre (NDF) content of fenugreek gum was also determined, but gels' production, due to its interaction with sugars, makes its determination ambiguous. The chemical composition methodology used is described in Section 2.3. As regards its physical properties, the bulk density of the FSG was determined using the method described by Narayana and Narasinga-Rao (1982). A calibrated tube was weighed and filled with a sample to $5 \mathrm{~mL}$ by constantly tapping until there was no further change in volume. Bulk density was then calculated as the weight determined by difference per unit volume of the sample. The solubility of the extract in cold water $\left(10-15^{\circ} \mathrm{C}\right)$ was also determined, adding $50 \mathrm{~mL}$ of cold water to $0.50 \mathrm{~g}$ of the FSG, as described by Torio et al. (2006). Finally, the FSG fermentation pattern was determined using the gas production technique. The rabbit caecal inoculum was obtained in the morning at the laboratory of the Higher School of Agriculture of Mateur (Cartago, Tunisia). Two New Zealand White adult rabbits were fasted overnight (with free access to 
freshwater) before slaughter at early morning. Once the whole gastro-intestinal tract had been isolated, caecal contents were collected, mixed and stirred for few minutes under $\mathrm{CO}_{2}$ bubbling. Finally, $100 \mathrm{~mL}$ of the mixture was homogenised under $1 \mathrm{~L}$ of solution A (including $10 \mathrm{~g} / \mathrm{L} \mathrm{KH}_{2} \mathrm{PO}_{4}, 0.5 \mathrm{~g} / \mathrm{L} \mathrm{Mg}_{2} \mathrm{SO}_{4} \cdot 7 \mathrm{H}_{2} \mathrm{O}, 0.5 \mathrm{~g} / \mathrm{L}$ $\mathrm{NaCl}$ and $0.1 \mathrm{~g} / \mathrm{L} \mathrm{CaCl}_{2} \cdot 2 \mathrm{H}_{2} \mathrm{O}$ ) and $8 \mathrm{~mL}$ of solution $\mathrm{B}$ (including $15 \mathrm{~g} / \mathrm{L} \mathrm{Na} \mathrm{CO}_{3}$ and $0.25 \mathrm{~g}$ Cysteine- $\mathrm{HCl}$ ) and the inoculum solution obtained was filtered through six layers of cheese cloth (Marten et al., 1979). Propylene sterile syringes of $60 \mathrm{~mL}$ were used for the incubation. Twenty $\mathrm{mL}$ of inoculum solution was included in each syringe, with $200 \mathrm{mg}$ of FSG or without for the blank. As a result of the low level of protein FSG, the incubations were performed without and with the addition of $0.5 \mathrm{~g} / \mathrm{L}$ of urea in the buffer (solutions $\mathrm{A}+\mathrm{B}$ ) to facilitate fermentation. A total of 22 syringes were used in this trial, three replicates for each of the three FSG extractions at two levels of urea addition, as well as another four for the blanks (inoculum solution without substrate). Syringes were quickly placed in an oven and incubated at $39^{\circ} \mathrm{C}$ for $28 \mathrm{~h}$. Gas production was recorded at $0.5,1,3,5,7,9,11,17,22,24,26$ and $28 \mathrm{~h}$ post inoculation. Gas production values at each measurement time were corrected for gas produced at this time by the corresponding blanks. Gas production data were fitted to the logistic model described by Schofield et al. (Schofield et al., 1994),

$$
G=\frac{V_{f}}{\left(1+e^{(2-4 k(t-L a g))}\right)}
$$

In this equation, $G(\mathrm{~mL})$ is the asymptotic amount of gas produced, $k\left(\mathrm{~h}^{-1}\right)$ is the fractional rate of gas production, Lag is the delay in the onset of gas production and $t$ is the incubation time. Maximum gas production rate $(\mu \mathrm{m}, \mathrm{mL} / \mathrm{h})$ and time at which $\mu \mathrm{m}$ is achieved $\left(t_{\mu m}\right)$ were also calculated as,

$$
\mu_{m}=k \times V_{f} \text { and } t_{\mu m}=\operatorname{Lag}+\left(V_{f} /\left(2 \times \mu_{m}\right)\right)
$$


Table 2.1. Ingredients $(\mathrm{g} / \mathrm{kg})$ and chemical composition $(\mathrm{g} / \mathrm{kg} \mathrm{DM})$ of the diets.

\begin{tabular}{lccc}
\hline & \multicolumn{3}{c}{ Experimental diets } \\
\cline { 2 - 4 } & Basal diet & SF & IF \\
\hline Ingredients & & & 221 \\
Wheat bran & 247 & 221 & 190 \\
Sunflower meal & 212 & 190 & 97 \\
Beet pulp & 108 & 197 & 100 \\
Grape seeds & 0 & 0 & 90 \\
Alfalfa hay & 100 & 90 & 72 \\
Wheat straw & 80 & 72 & 72 \\
Corn flour & 80 & 72 & 44 \\
Corn germ cake & 49 & 44 & 36 \\
Molasses & 40 & 36 & 27 \\
Rice bran & 30 & 27 & 22 \\
Corn grain & 25 & 22 & 11 \\
Calcium carbonate & 11 & 11 & 3 \\
Sodium chloride & 3 & 3 & 15 \\
Premix & 15 & 15 & \\
Chemical composition & & & 895 \\
Dry matter (DM, g/kg) & 898 & 896 & 66.4 \\
Ash & 70.0 & 70.1 & 169 \\
Crude protein & 176 & 168 & 415 \\
Neutral detergent fibre & 397 & 401 & 231 \\
Acid detergent fibre & 197 & 204 & 66.1 \\
Lignin acid detergent & 29.7 & 27.7 & 474 \\
Total dietary fibre & - & 489 & 59.0 \\
Soluble fibre & - & 88.1 & \\
\hline
\end{tabular}

${ }^{a}$ Commercial rabbit diet provided to the young rabbits after weaning. ${ }^{b}$ Supplied per $\mathrm{kg}$ of feed, Biolys, 1.2 g (0.66 g L-Lysine); Calcium chloride Hill, $0.15 \mathrm{~g}$; Lignobond, $10 \mathrm{~g}$ (lignosulphonate feed binder); Vitamin/trace element premix NL-310-Vita, $3.0 \mathrm{~g}$ (vitamin A, 8375 IU; vitamin D3, 750 IU; vitamin E, 20 mg; Vitamin K3, $1 \mathrm{mg}$; vitamin B1, $1 \mathrm{mg}$; vitamin B2, $2 \mathrm{mg}$; vitamin B6, $1 \mathrm{mg}$; nicotinic acid, $20 \mathrm{mg}$; choline chloride, $250 \mathrm{mg}$; magnesium, $290 \mathrm{mg}$; manganese, $20 \mathrm{mg}$; zinc, $60 \mathrm{mg}$; iodine, $1.25 \mathrm{mg}$; iron, $26 \mathrm{mg}$; copper, $10 \mathrm{mg}$; cobalt, $0.7 \mathrm{mg}$; butyl hydroxylanysole and ethoxiquin mixture, $4 \mathrm{mg}$ ); Luctanox, $0.2 \mathrm{~g}$ (antioxidant); Luctarom, $0.5 \mathrm{~g}$ (flavouring). Not determined. SF, soluble fibre; IF, insoluble fibre.

\section{In Vitro Digestive Behaviour}

As a potential prebiotic for rabbits, the in vitro digestive behaviour of FSG was evaluated, both in pure form and when included up to $20 \mathrm{~g} / \mathrm{kg}$ in diets rich in soluble or insoluble fibre. From a basal diet, two experimental diets were formulated to differ in their content in soluble and insoluble fibre provided by directly adding $100 \mathrm{~g} / \mathrm{kg}$ of beet pulp (diet SF) or $100 \mathrm{~g} / \mathrm{kg}$ of grape seeds (diet IF) to the basal diet respectively but maintaining minerals and premix supply. The 
diets were formulated to include $\mathrm{CP}$ and acid detergent fibre (ADF) levels close to the current recommendations (de Blas et al., 2010). Ingredients and chemical composition of the diets are given in Table 2.1.

From these experimental diets, 11 substrates were prepared, SF0, SF5, SF10, SF15 and SF20, SF diet including 0, 5, 10, 15 and $20 \mathrm{~g} / \mathrm{kg}$ of FSG, respectively. IF0, IF5, IF10, IF15 and IF20, IF diet including 0, 5, 10, 15 and $20 \mathrm{~g} / \mathrm{kg}$ of FSG respectively, and pure FSG. In a first step, the behaviour of the 11 substrates under an in vitro simulation of stomach and intestinal enzymatic digestion was evaluated. The enzymatic digestion was done according to the multi-enzymatic method of Ramos and Carabaño (Ramos and Carabaño, 1996). Using a Daisy incubator (Ankom Technology Corp, Macedon, NY, USA), three replicates of $0.5 \mathrm{~g}$ of each substrate were weighed in Ankom bags, placed in the Daisy incubator jar at 40 ${ }^{\circ} \mathrm{C}$ with $25 \mathrm{~mL} / \mathrm{bag}$ of the buffer solution $\mathrm{A}(0.1 \mathrm{M}$, a $\mathrm{pH}=6$; composed of $0.99 \mathrm{~g}$ of sodium phosphate dihydrate $\left(\mathrm{Na}_{2} \mathrm{HPO}_{4} \cdot 2 \mathrm{H}_{2} \mathrm{O}\right)$ and $14.72 \mathrm{~g}$ of sodium phosphate monobasic dihydrate $\left(\mathrm{NaH}_{2} \mathrm{PO}_{4} \cdot 2 \mathrm{H}_{2} \mathrm{O}\right)$ in $1 \mathrm{~L}$ of deionised water) with $10 \mathrm{~mL} / \mathrm{bag}$ of $0.2 \mathrm{M}$ hydrochloride solution, adjusting the $\mathrm{pH}$ value to 2 . At this level, pepsin solution $(0.025 \mathrm{~g} /$ sample and $\mathrm{mL}$ of $\mathrm{HCl} 0.2 \mathrm{M})$ was added to the jar and maintained for $2 \mathrm{~h}$. Then, $10 \mathrm{~mL} / \mathrm{bag}$ of the buffer $\mathrm{B}(0.2 \mathrm{M}, \mathrm{pH}=6.8$; composed of $9.65 \mathrm{~g}$ of sodium phosphate dihydrate $\left(\mathrm{Na}_{2} \mathrm{HPO}_{4} \cdot 2 \mathrm{H}_{2} \mathrm{O}\right)$ and $22.74 \mathrm{~g}$ of sodium phosphate monobasic dihydrate $\left(\mathrm{NaH}_{2} \mathrm{PO}_{4} \cdot 2 \mathrm{H}_{2} \mathrm{O}\right)$ in $1 \mathrm{~L}$ of deionised water), $5 \mathrm{~mL} / \mathrm{bag}$ of sodium hydroxide $(6 \mathrm{M})$ and $100 \mathrm{mg}$ of pancreatin/bag were added to the jar. Agitation was maintained for $3 \mathrm{~h}$ and $30 \mathrm{~min}$ at $40{ }^{\circ} \mathrm{C}$. At the end of the enzymatic digestion, the Ankom bags were washed over 3 times with distilled water at $40{ }^{\circ} \mathrm{C}$ and then dried at $105^{\circ} \mathrm{C}$ during $12 \mathrm{~h}$ in the stove. Finally, the bags were weighed to determine the indigestible fraction after pepsin and pancreatin enzymatic digestion. In a second step, the behaviour of the 11 substrates was evaluated, obtained during the enzymatic digestion under an in vitro simulation of caecal fermentation. The in vitro fermentation procedure was based on the method described by Fernández-Carmona et al. (1993). Five young 
rabbits from the LP line (Universitat Politècnica de València, Valencia, Spain) were weaned at 28 days of age and received a commercial rabbit diet until slaughter age (56 days of age). Rabbits had ad libitum access to feeders and fresh water during the trial without any antibiotic treatment. After slaughter, caecal content was collected and mixed in an anaerobic environment. Under constant $\mathrm{CO}_{2}$ bubbling, $400 \mathrm{~g}$ of the caecal mixture was homogenised with $340 \mathrm{~mL}$ of artificial saliva $\mathrm{NaHCO}_{3}(8 \mathrm{~g}), \mathrm{K}_{2} \mathrm{HPO}_{4}(4 \mathrm{~g}),\left(\mathrm{NH}_{4}\right) 2 \mathrm{HPO}_{4}(0.5 \mathrm{~g}), \mathrm{NaCl}(1.5 \mathrm{~g})$ and $\mathrm{MgSO}_{4} \cdot 7 \mathrm{H}_{2} \mathrm{O}(0.5 \mathrm{~g})$ per $\mathrm{L}$ of deionised water and filtrated through a cellulose filter. The filtrate was then centrifuged at $6000 \mathrm{rpm}$ and $38^{\circ} \mathrm{C}$ for $10 \mathrm{~min}$, and the supernatant was homogenised with another $500 \mathrm{~mL}$ of the artificial saliva under $\mathrm{CO}_{2}$ bubbling. Finally, the inoculum obtained was diluted up to 4 times the initial weight of caecal content by adding $1.6 \mathrm{~L}$ of artificial saliva. The inoculum solution was prepared on the day of fermentation, under constant $\mathrm{CO}_{2}$ at $38^{\circ} \mathrm{C}$, and the $\mathrm{pH}$ was adjusted to 6.9. A $0.7 \mathrm{~g}$ amount of each substrate was carefully weighed in a $120 \mathrm{~mL}$ bottle with $50 \mathrm{~mL}$ of inoculum. The bottle was sealed and incubated for $28 \mathrm{~h}$ in the stove with frequent gentle agitation. Two bottles were used for each substrate and other two for the blank (inoculum without any substrate). At the end of the incubation time, all bottles were placed in an ice bath to stop fermentation. Gas pressure was measured before opening the bottles. After opening, $\mathrm{pH}$ was determined, and one bottle was used to determine the unfermented fraction and the second bottle for total volatile fatty acids (VFA), VFA profile and $\mathrm{N}-\mathrm{NH}_{3}$. One hundred $\mu \mathrm{L}$ of $0.35 \mathrm{M} \mathrm{H}_{3} \mathrm{PO}_{4}$ (including 4-methyl valeric acid) or $3 \mathrm{~mL}$ of $0.35 \mathrm{M} \mathrm{H}_{2} \mathrm{SO}_{4}$ were added to $900 \mu \mathrm{L}$ of the fermentation product for later determination of VFA and $\mathrm{N}-\mathrm{NH}_{3}$. This in vitro simulation was repeated 3 times on different days.

\section{Chemical Analysis}

A preliminary qualitative phytochemical screening was carried out. Using an aqueous extract of the FSG obtained, the presence of steroids (Gibbs, 1974), 
terpenoids (Edeoga et al., 2005), flavonoids (Harborne, 1973), tannins (Evans, 2009), alkaloids (Amabye et al., 2016), saponins (Kumar et al., 2009), coumarins (Rizk et al., 1982) and reducing sugars (Benedict's test (Plummer, 1971)) were determined. FSG was analysed for DM, ash, CP and sugar content, as well as for amino acids and monomers profile of their protein and sugars, respectively. The diets were analysed for DM, ash, CP, NDF, acid detergent fibre (ADF) and acid detergent lignin (ADL), as well as for total dietary fibre (TDF) and soluble fibre in IF and SF diets. The indigestible fraction after pepsin and pancreatin digestion was analysed for DM, ash, CP, NDF, ADF, ADL and starch. Finally, the bottle content after fermentation was analysed for gas production, DM, pH, total VFA, VFA profile and $\mathrm{N}_{-} \mathrm{NH}_{3}$. Samples were analysed according to the methods of Association of Official Analytical Chemists (AOAC, 2002), 934.01 for DM, 942.05 for ash and 990.03 for CP. Starch content was determined according to Batey (Batey, 1982), by a two-step enzymatic procedure with solubilisation and hydrolysis to maltodextrins with thermostable $\alpha$-amylase followed by complete hydrolysis with amyloglucosidase (both enzymes from Sigma-Aldrich, Steinheim, Germany), and the resulting D-glucose being measured by the hexokinase/glucose-6 phosphate dehydrogenase/NADP system (kit D-glucoseHK Megazyme Int. Ireland Ltd, Wicklow, Ireland). The NDF, ADF and ADL were analysed sequentially by the AOAC. (2002) procedure 973.18 and Robertson and Van Soest. (1981) with a thermostable $\alpha$-amylase pre-treatment and expressed exclusive of residual ash, using a nylon filter bag system (Ankom Technology Corp, Macedon, NY, USA). The TDF content was determined by a gravimetricenzymatic method, the procedure 991.43 of the Van Soest et al. (1991), with $\alpha$ amylase, protease and amyloglucosidase treatments (Megazyme TDF R.30.KTDFR-100A/200A), correcting for ash and CP (method 985.29). Hemicellulose, cellulose and soluble fibre contents were calculated by difference as NDF - ADF, ADF - ADL and TDF - NDF, respectively. The amino acid content of FSG protein was determined after acid hydrolysis with $\mathrm{HCl} 6 \mathrm{~N}$ at $110{ }^{\circ} \mathrm{C}$ for $23 \mathrm{~h}$, as 
previously described by Bosch et al. (2006), using Waters (Milford, MA, USA) HPLC system consisting of two pumps (Model 515, Waters, Milford, MA, USA), an auto-sampler (Mod. 717, Waters, Milford, MA, USA), a fluorescence detector (Mod. 474, Waters, Milford, MA, USA) and a temperature control module. Aminobutyric acid was added as an internal standard after hydroxylation. The amino acids were derivatised with AQC (6-aminoquinolyl-Nhydroxysuccinimidyl carbamate) and separated with a C-18 reverse-phase column Waters AQC Tag $(150 \times 3.9 \mathrm{~mm})$. Methionine and cysteine were determined separately as methionine sulfone and cysteic acid respectively, after performic acid oxidation followed by acid hydrolysis. To determine total VFA concentration and VFA profile, samples were centrifuged for 5 min during 15,000 $\mathrm{rpm}$, and $300 \mu \mathrm{L}$ from the supernatant was filtrated through a syringe filter with porosity of $0.22 \mu$. Then, $200 \mu \mathrm{L}$ of the filtrate was recuperated in an injection vial. Two microlitres from each sample were injected into the gas chromatograph (Fisons 8000 series, Milan, Italy) equipped with an AS800 automatic injector. The column used was a BD-FFAP $30 \mathrm{~m} \times 0.25 \mathrm{~mm} \times 0.25 \mathrm{~mm}$. Injector and detector temperatures were maintained at 220 and $225^{\circ} \mathrm{C}$, respectively. For $\mathrm{N}-\mathrm{NH}_{3}, 3 \mathrm{~mL}$ of sulphuric acid $(0.35 \mathrm{M})$ was mixed with $1 \mathrm{~g}$ of fermentation product. Ammonia concentration was determined according to procedure 984.13 of the AOAC (2002). The VFA and $\mathrm{N}-\mathrm{NH}_{3}$ concentrations were expressed as mmol L-1 of the liquid phase of fermentation product.

\section{Statistical Analysis}

Digested, fermented and neither digested nor fermented FSG fractions were calculated in DM basis. The indigestible and unfermented fractions were calculated concerning the DM of the initial FSG and the indigestible fraction, respectively. Data on gas production kinetics were analysed using a general linear model (GLM) procedure of SAS (2009), with a model including the urea addition $(0$ and $0.5 \mathrm{~g} / \mathrm{L})$ as a fixed effect. Data corresponding to the content and 
composition of the indigestible and unfermented fractions were analysed using a GLM procedure of SAS (SAS Institute Inc, Cary, NC, USA) (2009) with a model including the substrate (SF0, SF5, SF10, SF15, SF20, IF0, IF5, IF10, IF15, IF20 and FSG) as a fixed effect. Different contrasts were computed to test the significance of the differences between diets $(\mathrm{SF}-\mathrm{IF}=\mathrm{SF} 0+\mathrm{SF} 5+\mathrm{SF} 10+\mathrm{SF} 20-\mathrm{IF} 0-\mathrm{IF} 5-$ IF10 - IF20)/5), of the inclusion of pure FSG (0 versus $1000=($ SF0 + IF0)/2 - FSG), and of the linear effect of the FSG in all diets, SF diets and IF diets.

\section{Results}

FSG extracted was a white powder, with low humidity ( $88 \mathrm{~g} / \mathrm{kg})$ and ashes (13 $\mathrm{g} / \mathrm{kg} \mathrm{DM})$, and a moderate protein content (223 $\mathrm{g} / \mathrm{kg} \mathrm{DM})$, whose profile is shown in Table 2.2. As expected, FSG was rich in total sugars (630 g/kg DM), consisting entirely of galactose and mannose, in a ratio of 1,1 . In contrast, it can be seen that there is $134 \mathrm{~g} / \mathrm{kg}$ that should correspond to some type of fibrous fraction. However, when trying to determine these fibrous fractions sequentially, the gels formed interacted with the sugars, rendering such determination ambiguous, so it was discarded. The preliminary qualitative phytochemical screening tests reported that the FSG contained traces of flavonoids, tannins and coumarins, while it had no steroids, terpenoids, alkaloids, saponins or reducing sugars. FSG had a bulk density of $0.2 \pm 0.04 \mathrm{~g} / \mathrm{mL}$ and solubility in cold water of $0.0042 \mathrm{~g} / \mathrm{mL}$. Table 2.3 shows the gas production kinetics of FSG after $28 \mathrm{~h}$ in vitro fermentation, when adjusted to a logistic model. The inclusion of urea in the buffer led to a decrease in $k(-0.03 \pm 0.01 \mathrm{~h}-1 ; p<0.05), \operatorname{Lag}(-2.04 \pm 0.34 \mathrm{~h} ; p<0.01), \mu_{m}(-0.60 \pm$ $0.18 \mathrm{~h} ; p<0.05)$ and $t_{\mu m}$ values $(-1.35 \pm 0.18 \mathrm{~h} ; p<0.01)$. Table 2.4 shows the effect of FSG inclusion in the experimental diets on the amount and composition of the indigestible fraction after in vitro enzymatic digestion with pepsin and pancreatin. 
Table 2.2. Chemical composition of fenugreek gum.

\begin{tabular}{lc}
\hline Chemical composition & $(\mathrm{g} / \mathrm{kg} \mathrm{DM})$ \\
\hline Dry matter (DM) $(\mathrm{g} / \mathrm{kg})$ & 913 \\
Ashes & 12.7 \\
Crude protein (CP) & 223 \\
Sugars & 630 \\
Sugar composition (g/kg sugars), & \\
Galactose & 515 \\
Mannose & 485 \\
Fructose & $<1$ \\
Glucose & $<1$ \\
Lactose & $<1$ \\
Maltotriose & $<1$ \\
Galactose/mannose ratio & 1.1 \\
Amino acid composition (g/kg CP), & \\
Alanine & 25.9 \\
Arginine & 76.3 \\
Aspartate & 107 \\
Cysteine & 13.4 \\
Glutamate & 172 \\
Glycine & 27.9 \\
Histidine & 22.3 \\
Isoleucine & 47.9 \\
Leucine & 64.1 \\
Lysine & 57.9 \\
Methionine & 9.10 \\
Phenylalanine & 33.1 \\
Proline & 32.9 \\
Serine & 39.4 \\
Threonine & 23.1 \\
Tyrosine & 15.2 \\
Valine & 32.1 \\
\hline Neutral detergent fibre content of fenugreek gum was also determined $(730.6$ & $\mathrm{g} / \mathrm{kg} \mathrm{DM}), \mathrm{but}$ gel \\
production during analysis made its determination uncertain. & \\
\hline
\end{tabular}

When the experimental diets are compared, the indigestible fraction of the SF diets had less NDF, ADF and ADL (from 47 to $75 \mathrm{~g} / \mathrm{kg} ; p<0.001$ ), but slightly more CP $(7 \mathrm{~g} / \mathrm{kg} ; p<0.001)$ than the indigestible fraction of the IF diets. Pure FSG was affected very little by in vitro enzymatic digestion, only $145 \mathrm{~g} / \mathrm{kg}$ of the FSG was dissolved during the enzymatic digestion compared to $465 \mathrm{~g} / \mathrm{kg}$ of experimental diets ( $p<0.001$; Figure 2.1, dark grey bars). 
Table 2.3. Effect of urea addition in the buffer on gas production kinetics of fenugreek seed gum in $28 \mathrm{~h}$ in vitro incubations with caecal inoculum ( $\mathrm{n}=9$ for each level).

\begin{tabular}{|c|c|c|c|c|}
\hline \multirow[b]{2}{*}{ Gas production kinetics a } & \multicolumn{2}{|c|}{ Urea Addition $(\mathrm{g} / \mathrm{mL})$} & \multirow[b]{2}{*}{ SEM } & \multirow[b]{2}{*}{$p$-Value } \\
\hline & 0 & 0.5 & & \\
\hline$V_{f}(\mathrm{~mL})$ & 24.46 & 24.92 & 1.597 & 0.8545 \\
\hline$k\left(\mathrm{~h}^{-1}\right)$ & 0.152 & 0.126 & 0.006 & 0.0318 \\
\hline $\operatorname{Lag}(\mathrm{h})$ & 6.118 & 4.077 & 0.245 & 0.0047 \\
\hline$\mu_{m}(\mathrm{~mL} / \mathrm{h})$ & 3.722 & 3.119 & 0.130 & 0.0340 \\
\hline$t_{\mu m}(\mathrm{~h})$ & 9.411 & 8.063 & 0.127 & 0.0019 \\
\hline
\end{tabular}

${ }^{a} V_{f}$, asymptotic gas production; $k$, fractional rate of gas production; Lag, initial delay in the onset of gas production; $\mu_{m}$ maximum gas production rate; $t_{\mu m}$, time when $\mu_{m}$ is reached (logistic model described by Schofield et al. (1994)). SEM, standard error of the mean.

The indigested fraction of pure FSG was richer in crude protein $(+55 \pm 4 \mathrm{~g} / \mathrm{kg} ; p<$ $0.001)$ and poorer in starch $(-39 \pm 6 \mathrm{~g} / \mathrm{kg} ; p<0.001)$ than the indigestible fraction of the experimental diets. FSG inclusion up to $20 \mathrm{~g} / \mathrm{kg}$ significantly increased the indigestible fraction of the diets, mainly due to its effect on SF diets $(+1.4 \mathrm{~g} / \mathrm{kg}$ per each $\mathrm{g} / \mathrm{kg}$ of FSG added; $p<0.001)$.

Table 2.4. Effect of fenugreek seed gum (FSG) inclusion in the experimental diets (SF and FI) on the amount and composition of the indigestible fraction after an in vitro enzymatic digestion with pepsin and pancreatin (least square means \pm standard error).

\begin{tabular}{|c|c|c|c|c|c|c|}
\hline \multirow[b]{2}{*}{ Traits } & \multirow[b]{2}{*}{ Mean } & \multicolumn{2}{|c|}{ Contrasts ${ }^{1}$} & \multicolumn{3}{|c|}{ Linear Effect of FSG Inclusion } \\
\hline & & SF vs IF & 0 vs 1000 & All Diets & SF Diets & IF Diets \\
\hline Indigestible fraction $(\mathrm{g} / \mathrm{kg})$ & 560.8 & $-4.05 \pm 2.68$ & $-319.5 \pm 6.1^{* * * *}$ & $0.86 \pm 0.02^{* * *}$ & $1.43 \pm 0.27^{* * *}$ & $0.29 \pm 0.27$ \\
\hline \multicolumn{7}{|c|}{ Indigestible fraction composition $(\mathrm{g} / \mathrm{kg})$, } \\
\hline Crude protein & 116.5 & $7.45 \pm 1.60^{* * *}$ & $-54.5 \pm 3.1^{* * *}$ & $0.39 \pm 0.11^{* *}$ & $0.70 \pm 0.16^{* *}$ & $0.01 \pm 0.16$ \\
\hline Neutral detergent fibre & 673.6 & $-46.70 \pm 2.22^{* *+4}$ & & $-0.79 \pm 0.15^{* * *}$ & $-1.57 \pm 0.22^{* * * *}$ & $-0.01 \pm 0.22$ \\
\hline Acid detergent fibre & 381.9 & $-64.27 \pm 3.96^{* * *+}$ & & $-0.41 \pm 0.28$ & $-1.08 \pm 0.40^{*}$ & $0.25 \pm 0.40$ \\
\hline Lignin acid detergent & 101.2 & $-74.75 \pm 3.30^{* * *+}$ & & $0.13 \pm 0.23$ & $-0.16 \pm 0.33$ & $0.42 \pm 0.33$ \\
\hline Hemicellulose & 291.7 & $17.57 \pm 3.36^{* * *}$ & & $-0.38 \pm 0.24$ & $-0.49 \pm 0.34$ & $-0.26 \pm 0.34$ \\
\hline Cellulose & 280.8 & $10.48 \pm 2.03^{* * * *}$ & & $-0.55 \pm 0.14^{* *}$ & $-0.92 \pm 0.20^{* *}$ & $-0.17 \pm 0.20$ \\
\hline Starch & 41.5 & $-3.49 \pm 2.20$ & $39.1 \pm 4.3^{* * *}$ & $0.56 \pm 0.16^{* *}$ & $0.93 \pm 0.22^{* * *}$ & $0.20 \pm 0.22$ \\
\hline
\end{tabular}

${ }_{1}^{1} \mathrm{SF}$, soluble fibre diets; IF, insoluble fibre diets; FSG 0 versus 1000, FSG inclusion level $(\mathrm{g} / \mathrm{kg}$ dry matter), $0((\mathrm{SF} 0+\mathrm{IF} 0) / 2)$ and 1000 (pure FSG). Significance, ${ }^{*} p<0.05 ;{ }^{* *} p<0.01 ; * * * 0.001$. 


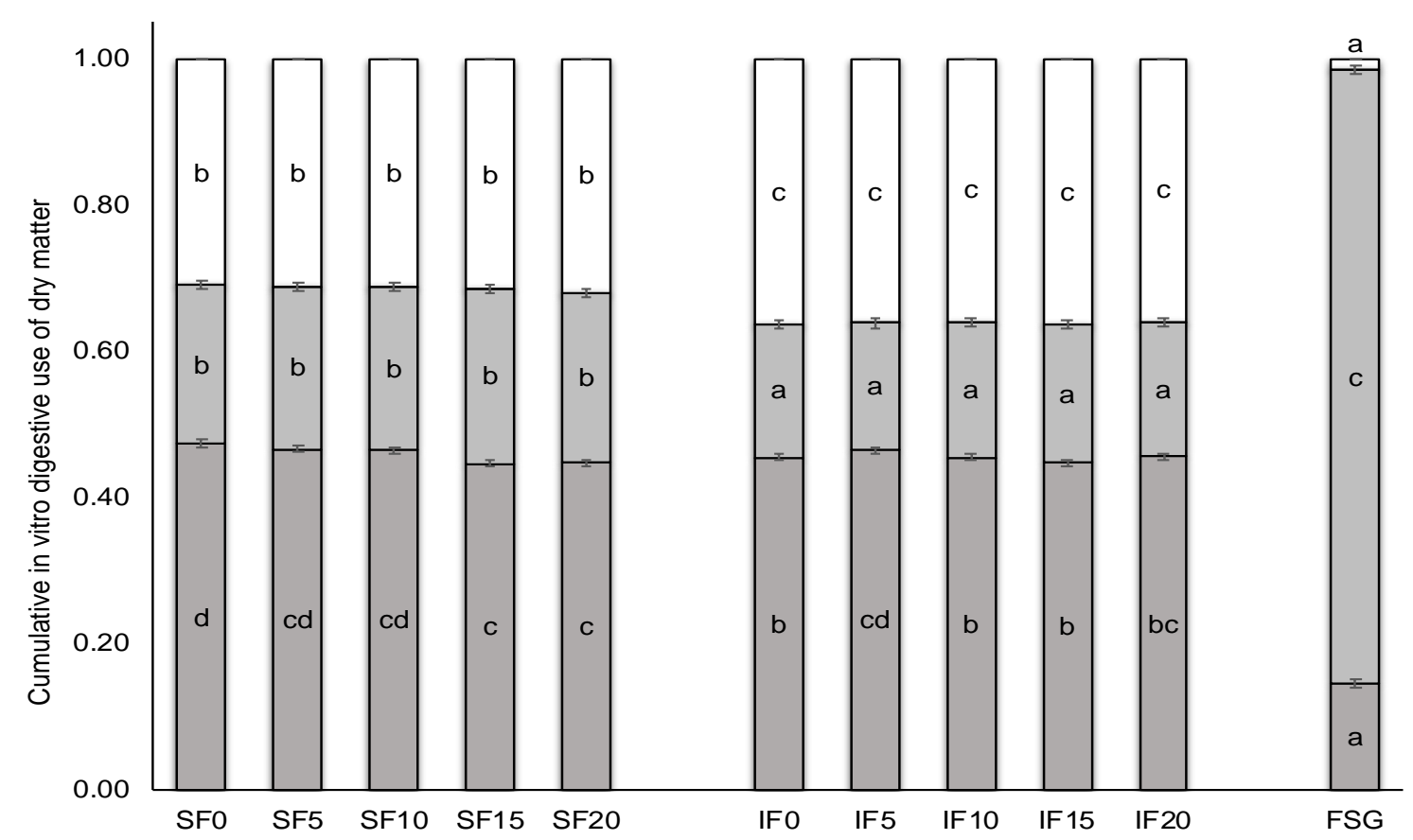

Figure 2.1. Effect of fenugreek seed gum (FSG) level of inclusion in the experimental diets (SF and IF) on their cumulative in vitro digestive use of dry matter (DM): digested faction (dark grey), fermented fraction (light grey) and fraction neither digested nor fermented (white). FSG, pure fenugreek seed gum; SF0, SF5, SF10, SF15 and SF20, SF diet with $0,5,10,15$ and $20 \mathrm{~g}$ of FSG included per kg of feed; IF0, IF5, IF10, IF15 and IF20, IF diet with $0,5,10,15$ and $20 \mathrm{~g}$ of FSG included per kg of feed. a, b, c, d Bars for each fraction not sharing a letter were significantly different at $\mathrm{p}<0.05$.

In addition, FSG inclusion linearly increased the starch and CP content of the indigestible fraction but decreased the NDF and cellulose $(+0.4,+0.6,-0.8$ and -0.6 $\mathrm{g} / \mathrm{kg}$ per each $\mathrm{g} / \mathrm{kg}$ of FSG added, respectively; $p<0.001)$. However, this modification of indigestible fraction associated with linear inclusion of FSG was only observed in FS diets $(+0.7,+0.9,-1.6$ and $-0.9 \mathrm{~g} / \mathrm{kg}$ per each $\mathrm{g} / \mathrm{kg}$ of FSG added; $p<0.001$ ), being unaffected in IF diets (Figure 2.2). Finally, Table 2.5 shows the effect of FSG inclusion in the experimental diets on the unfermented fraction and some fermentative traits after an in vitro fermentation with caecal inoculum of the indigestible fraction previously obtained. 


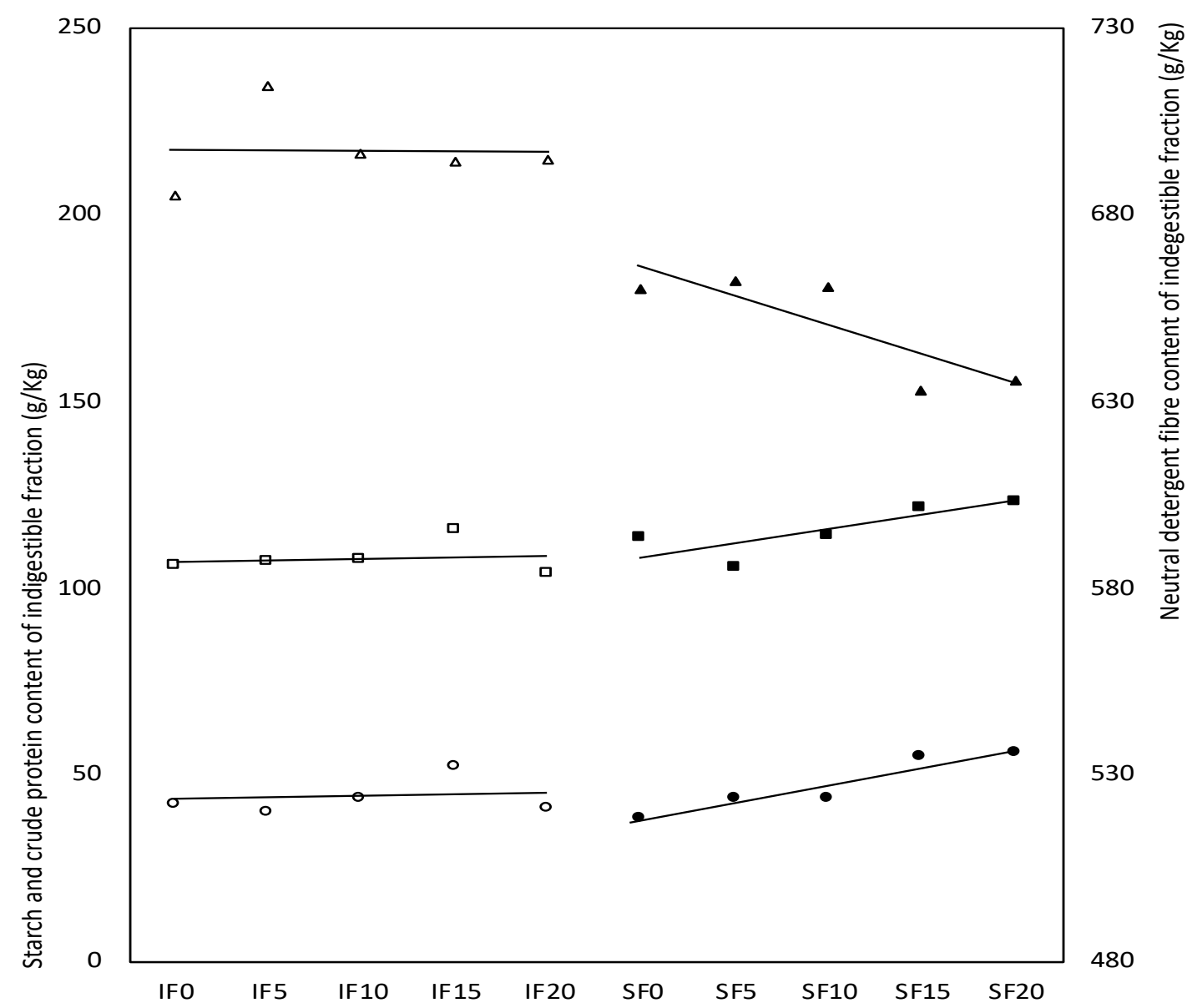

Figure 2.2. Effect of fenugreek seed gum (FSG) level of inclusion in the experimental diets (SF and IF) on the $O$ starch, $\square$ crude protein and $\triangle$ neutral detergent fibre content of indigestible fraction after in vitro incubation with pepsin and pancreatin (symbols without filling in IF diets and with filling in SF diets). SF0, SF5, SF10, SF15 and SF20, SF diet with 0, 5, 10, 15 and $20 \mathrm{~g}$ of FSG included per $\mathrm{kg}$ of feed; IF0, IF5, IF10, IF15 and IF20, IF diet with $0,5,10,15$ and $20 \mathrm{~g}$ of FSG included per $\mathrm{kg}$ of feed.

When the experimental diets are compared, indigestible fraction of SF diets is more fermented $(+83 \mathrm{~g} / \mathrm{kg} ; p<0.001)$ with a greater gas production $(+0.15 \mathrm{mbar}$; $p<0.001)$ and total VFA $(+5.7 \mathrm{mmol} / \mathrm{L} ; p<0.001)$, whose profile contained a lower proportion of butyric, isobutyric and isovaleric acids $(-2.3,-0.1$ and -0.1 percentage points; $p<0.05)$. In addition, $\mathrm{pH}$ and $\mathrm{N}-\mathrm{NH}_{3}$ content of the final fermentation product was also lower with the SF diet than with IF ( -0.12 points and $-15.4 \mathrm{mmol} / \mathrm{L}$, respectively; $p<0.001)$. 
Table 2.5. Effect of fenugreek seed gum (FSG) inclusion in the experimental diets (SF and FI) on some fermentation traits after an in vitro fermentation with caecal inoculum of the indigestible fraction obtained from the in vitro enzymatic digestion with pepsin and pancreatin (least square means \pm standard error).

\begin{tabular}{lcccccc}
\hline & & \multicolumn{2}{c}{ Contrasts $^{1}$} & \multicolumn{2}{c}{ Linear Effect of FSG Inclusion } \\
\cline { 3 - 7 } Traits & Mean & SF vs IF & 0 vs 1000 & All Diets & SF Diets & IF Diets \\
\hline Unfermented fraction $(\mathrm{g} / \mathrm{kg})$ & 566.9 & $-83.1 \pm 3.7^{* * * *}$ & $610.8 \pm 7.1^{* * * *}$ & $-0.6 \pm 0.3^{*}$ & $-0.7 \pm 0.4$ & $-0.6 \pm 0.4$ \\
Gas pressure (mbar) & 0.62 & $0.15 \pm 0.02^{* * *}$ & $-0.61 \pm 0.03^{* * *}$ & $0.00 \pm 0.00$ & $0.00 \pm 0.00$ & $0.00 \pm 0.00$ \\
pH & 6.18 & $-0.12 \pm 0.02^{* * * *}$ & $0.68 \pm 0.03^{* * *}$ & $0.00 \pm 0.00$ & $0.00 \pm 0.00$ & $0.00 \pm 0.00$ \\
Total VFA (mmol/L) & 19.49 & $5.72 \pm 1.46^{* * *}$ & $-27.32 \pm 3.31^{* * *}$ & $0.03 \pm 0.10$ & $-0.04 \pm 0.15$ & $0.11 \pm 0.15$ \\
VFA profile (\%), & & & & & & \\
$\quad$ Acetate & 63.25 & $1.94 \pm 1.64$ & $4.28 \pm 3.72$ & $-0.05 \pm 0.12$ & $-0.11 \pm 0.16$ & $0.01 \pm 0.16$ \\
$\quad$ Propionate & 11.63 & $0.21 \pm 0.38$ & $-3.08 \pm 0.87^{* *}$ & $0.05 \pm 0.03$ & $0.05 \pm 0.04$ & $0.04 \pm 0.04$ \\
$\quad$ Butyrate & 21.84 & $-2.29 \pm 1.04^{*}$ & $-2.12 \pm 2.35$ & $-0.02 \pm 0.07$ & $0.01 \pm 0.10$ & $-0.06 \pm 0.10$ \\
Iso-butyrate & 0.37 & $-0.07 \pm 0.03^{* *}$ & $-0.15 \pm 0.06^{*}$ & $0.00 \pm 0.00$ & $0.00 \pm 0.01$ & $0.00 \pm 0.00$ \\
$\quad$ Valerate & 0.70 & $0.02 \pm 0.04$ & $0.26 \pm 0.09^{*}$ & $0.01 \pm 0.00^{*}$ & $0.01 \pm 0.00^{*}$ & $0.00 \pm 0.00$ \\
$\quad$ Isovalerate & 0.31 & $-0.09 \pm 0.04^{*}$ & $-0.49 \pm 0.09^{* * *}$ & $0.00 \pm 0.00$ & $0.01 \pm 0.00$ & $0.00 \pm 0.00$ \\
Caproate & 1.83 & $0.27 \pm 0.17$ & $1.23 \pm 0.39^{* * *}$ & $0.01 \pm 0.01$ & $0.03 \pm 0.02$ & $-0.00 \pm 0.02$ \\
$\quad$ Heptanoate & 0.09 & $0.01 \pm 0.02$ & $0.06 \pm 0.04$ & $0.00 \pm 0.00$ & $0.00 \pm 0.00$ & $0.00 \pm 0.00$ \\
$\mathrm{~N}-\mathrm{NH} 3$ (mmol/L) & 28.89 & $-15.39 \pm 3.09^{* * * *}$ & $65.15 \pm 5.89^{* * * *}$ & $0.33 \pm 0.22$ & $0.67 \pm 0.33$ & $-0.00 \pm 0.29$ \\
\hline
\end{tabular}

${ }^{1}$ Mean value obtained with respect to the blank (caecal inoculum without any substrate addition); soluble fibre diets; IF, insoluble fibre diets; 0 versus 1000, FSG inclusion level (g/kg dry matter), $0((\mathrm{SF} 0+\mathrm{IF} 0) / 2)$ and 1000 (pure FSG). VFA, volatile fatty acids. Significance, ${ }^{*} p<0.05 ;{ }^{* *} p<0.01$; ${ }^{* * *} p<0.001$.

Indigestible fraction of pure FSG was almost completely used during in vitro fermentation, at $984 \mathrm{~g} / \mathrm{kg}$ of the indigestible fraction. As shown in Figure 2.1 (clear green bars), FSG $841 \mathrm{~g} / \mathrm{kg}$ of the initial FSG was fermented, clearly higher $(p<0.001)$ than the fermented fraction of SF diets (on average, $226 \mathrm{~g} / \mathrm{kg}$ ), which was significantly higher than that of IF diets (on average, $183 \mathrm{~g} / \mathrm{kg}$ ).

Comparing it to diets without FSG, pure FSG reduced the $\mathrm{pH}$ and concentration of $\mathrm{N}-\mathrm{NH}_{3}$ after fermentation $(p<0.001)$. It also produced a clear increase in gas production and total VFA content $(p<0.001)$, whose profile was enriched in propionic, isobutyric and isovaleric, and depleted in valeric and caproic acids. In addition, linear dietary FSG inclusion increased the fermented fraction and the relative proportion of valeric acid $(+0.6 \mathrm{~g} / \mathrm{kg}$ and +0.01 percentage points per each $\mathrm{g} / \mathrm{kg}$ of FSG added; $p<0.05)$. However, this modification of relative proportion of valeric acid associated with linear inclusion of FSG was only observed in FS 
diets (+0.01 percentage points per each $\mathrm{g} / \mathrm{kg}$ of FSG added; $p<0.05)$, being unaffected in IF diets.

\section{Discussion}

In the current research work, our main purpose was to evaluate the potential prebiotic effect of FSG, both pure and when included up to $20 \mathrm{~g} / \mathrm{kg}$ in diets rich in soluble or insoluble fibre, as its prebiotic potential could be different depending on the nature of the main dietary fibre.

For this reason, in the present work, we initially characterised the FSG extracted, and subsequently, using an enzymatic digestion and fermentation simulation, evaluated the digestive and fermentative behaviour of the FSG pure or when added to diets differing in soluble or insoluble fibre. Regarding FSG chemical composition, the preliminary analysis of phytochemicals seems to indicate that FSG only contains traces of some phenolic compounds, and absence of alkaloids, steroids, terpenoids and reducing sugars. Therefore, a priori, the FSG extract obtained would not present anti-nutritive factors or a level of toxicity that negatively affects rabbits' performance when included in their diets. Accordingly, Deshpande et al. (2016) evaluated the possible toxicity in rats of an extract of fenugreek seeds, rich in galactomannan of low molecular weight, and observed that their inclusion up to $1000 \mathrm{mg} / \mathrm{kg} /$ day did not produce negative effects on ingestion, haematology, biochemistry and histology of animals, even in mutagenicity, and can be considered safe. FSG is mostly composed of galactomannan (galactose and mannose, $630 \mathrm{~g} / \mathrm{kg}$ ). Similar results $(635 \mathrm{~g} / \mathrm{kg}$ ) were found by Majeed et al. (2018) for a commercial galactomannan from fenugreek seeds. The purity reported for other galactomannans obtained from carob and mesquite seeds was greater, above 940 g/kg (Mc Cleary, 1988; ChairesMartínez et al., 2008). These purity values were higher than those obtained for FSG due to two possible reasons, the separation of the endosperm from the seeds and the purification processes, as the extraction procedure is almost the same. In 
the case of fenugreek seeds, endosperm cannot be separated, and the purification procedure is expensive. A further improvement in this process could improve the potential of the results obtained with the FSG. In our case, the FSG extract obtained had a moderate content in CP $(223 \mathrm{~g} / \mathrm{kg} \mathrm{DM})$, with an amino acid profile quite similar to that obtained for fenugreek seed protein (Nour and Magboul, 1986). Gas production kinetics can reflect the extent to which substrates are used by caecal microbiota (Schofield, 2000). FSG was highly fermented by rabbits' caecal microflora because of its high carbohydrate content, which is positively correlated with the maximum cumulative volume of gas production (Piquer et al., 2009). The fermentative behaviour of FSG was similar to that shown by other soluble fibre sources in rabbits (Abad-Guamán et al., 2018; Ocasio-Vega et al., 2018), having a maximum gas production rate ( 3.1 to $3.7 \mathrm{~mL} / \mathrm{h}$ ) between that of sugar beet pulp $(2.9 \mathrm{~mL} / \mathrm{h})$ and that of pectin $(6.0$ to $8.0 \mathrm{~mL} / \mathrm{h})$. The high level of microbial fermentation of FSG might imply high energy losses, which may require a nitrogen source supplementation. This fact could explain the increase in the fractional and maximum gas production rates with the urea addition. As expected, diets enriched in SF (sugar beet pulp) showed a higher degree of enzymatic digestion and fermentation in vitro than diets enriched in IF (grape seeds). Trocino et al. (2013a), in a meta-analysis, concluded that an increase in SF to TDF ratio increases both digested and fermented TDF. TDF digestibility seems to increase because of the high digestibility of $\mathrm{SF}$, and the low lignification level of the raw materials rich in SF. The experimental diets did not differ too much in $\mathrm{NDF}$, but ADF and ADL were clearly lower in SF diets. On the other hand, SF stimulates the growth of fibrolytic microbiota in the gut (Gómez-Conde et al., 2009), and consequently, fibre fermentation, reduction of caecal $\mathrm{pH}$ and production of VFA, usually promoting acetate with respect to butyrate, as in the present work (Trocino et al., 2013b). 
Gibson and Roberfroid (1995) defined a prebiotic as "a non-digestible fibre in the upper gastro-intestinal tract which can enhance the growth or activity of advantageous bacteria of large bowel by acting as a substrate for them". Later, Roberfroid (Roberfroid, 2007) added that a prebiotic is "a selectively fermented ingredient that allows specific changes both in the composition and/or activity in the gastro-intestinal microflora that confers wellbeing and health benefits for the host'. This means that to be prebiotic, a feed ingredient should have a composition that would allow it to be not only non-digestible in the gastrointestinal tract but also highly fermentable in the caecum and the colon (as in the case of rabbits). These characteristics have been clearly fulfilled by the pure FSG, as it was little affected by in vitro enzymatic digestion and almost completely used up during in vitro fermentation. These results agree with those obtained by Majeed et al. (2018), who observed that when fenugreek seed galactomannan was subjected to gastric and subsequently pancreatic digestion, the release of reducing sugars was practically nil. In addition, Majeed et al. (2018) also observed that Bacillus coagulans could grow in a medium that only included fenugreek seeds galactomannan as nutrient $(0.5 \% w / v)$, showing a better count compared to that observed with other prebiotics such as fructooligosaccharides, confirming FSG's potential as a prebiotic. Therefore, it seems that FSG promotes substrate fermentation by the rabbit caecal microbiota, reducing the caecal $\mathrm{pH}$, increasing the production of total VFA and consuming the N-NH3 available in the medium by the action of the fibrolytic bacteria (Gidenne, 2015).

Regarding the fermentation profile, the results seem to show that pure FSG increases the proportion of propionate, iso-butyrate and isovalerate, but reduces caproate when compared to the profile obtained with experimental diets, while the inclusion of soluble fibre from beet pulp promotes the proportion of butyrate and isovalerate regarding the inclusion of lignin from grape seeds. Marounek et al. (1997) observed that the molar proportions of propionate and caproate were 
promoted when rabbit caecal cultures were supplied with inulin and starch, respectively. Thus, the inclusion of prebiotic additives, such as inulin or fenugreek gum, seems to promote the proportion of propionate, while feeds with higher starch content would lead to a higher proportion of caproate. However, the inclusion of beet pulp, with a proven prebiotic effect in rabbits, leads to a different profile. This may be due to the fact that, during the enzymatic digestion, diets rich in beet pulp produce an indigestible fraction richer in highly fermented hemicellulose and cellulose, which promote butyrate production when they reach the caecum (García et al., 2002). In the case of isobutyrate, isovalerate and valerate, they are not produced by fermentation of carbohydrates but from the degradation of the amino acids, valine, leucine and proline (Van Soest, 1994). The higher proportion of iso-butyrate and iso-valerate during fermentation of pure FSG may be related to its relatively high protein content (223 g/kg DM), which was also rich in leucine and had a non-negligible valine content. Linear increase of FSG inclusion up to $20 \mathrm{~g} / \mathrm{kg}$ reduced the digestive use of the diets enriched in soluble fibre during the enzymatic digestion. As the only dietary change in SF diets was the inclusion of $100 \mathrm{~g} / \mathrm{kg}$ of sugar beet pulp, it seems that the inclusion of FSG as a prebiotic could be altering the solubilisation of the sugar beet pulp during the enzymatic digestion with pepsin and pancreatin. On the other hand, in the indigestible fraction obtained with SF diets, protein and starch proportions were increased, but the fibre fractions proportions were reduced as the FSG increased (e.g, $-1.6 \mathrm{~g} / \mathrm{kg}$ of NDF per each $\mathrm{g} / \mathrm{kg}$ of FSG added). Other authors observed that an increase of soluble fibre increased the faecal and ileal digestibility of the main fibre fractions of the diet (on average, 0.6 to $0.8 \mathrm{~g} / \mathrm{kg}$ of soluble NDF per each $\mathrm{g} / \mathrm{kg}$ of soluble fibre added; Trocino et al. (2013b) and Gómez-Conde et al. (2009)). However, this effect has not been observed when other potential prebiotics have been included in the diet of growing rabbits (e.g, inulin; Volek and Marounek, 2011). These results may be related to some of the physical aspects of gums such as FSG. Some studies (Owusu-Asiedu et al., 2006; 
Dartois et al., 2010) have reported that the dietary inclusion of gums reduced starch and protein hydrolysis during simulated gastric and intestinal digestion. Gums may be acting by forming a barrier layer around the feed or increasing digesta viscosity that could restrict the access of the enzymes to the granules of starch and protein of the digesta, reducing its solubilisation, especially in diets enriched with sugar beet pulp (Trocino et al., 2013a). Finally, although FSG was almost totally fermented by the rabbit caecal bacteria, its inclusion up to $20 \mathrm{~g} / \mathrm{kg}$ in the diet only slightly increased the in vitro fermentation of the diets where they were included (probably related to its own disappearance), without relevant changes in the in vitro fermentation profile observed in the caecum content of the rabbits, with only a slight increase in the content of valerate.

\section{Conclusions}

In the present work, we have tried to evaluate the potential of an extract of FSG, rich in galactomannan, as a functional product with prebiotic activity for growing rabbits. In this way, FSG satisfies two essential conditions of the prebiotic effect, it shows resistance to in vitro enzymatic digestion and was totally fermented in vitro by caecal bacteria. Consequently, pure FSG promoted the caecal fermentation as expected for a prebiotic, reducing caecal $\mathrm{pH}$ and $\mathrm{N}-\mathrm{NH}_{3}$ content, increasing total VFA production and modulating VFA profile. However, FSG linear inclusion up to $20 \mathrm{~g} / \mathrm{kg}$ in growing feeds led to a slight reduction in the solubility of some nutrients during the in vitro enzymatic digestion, and although FSG increased the fermentation fraction of the diets, no relevant changes in the fermentation profile were observed. For this reason, it is necessary to perform in vivo studies with different sources of fibre to truly determine the prebiotic efficiency of FSG rich in galactomannan. 


\section{Acknowledgments}

We appreciate the help of the Higher School of Agriculture of Mateur (Tunisia), which provided us with one of its laboratories during the galactomannan extraction process.

\section{References}

Abad-Guamán R, Larrea-Dávalos J. A, Carabaño R, García J, Carro M. D. 2018. Influence of inoculum type (ileal, caecal and faecal) on the in vitro fermentation of different sources of carbohydrates in rabbits. World Rabbit Science, 26, 227-240.

Aguilar J. C, Roca T, Sanz E. 1996. Fructo-oligosaccharides in rabbit diet. Study of efficiency in suckling and fattening periods. In: Proceedings of the $6^{\text {th }}$ World Rabbit Congress, Toulouse, France, 9-12 July 1996, pp. 73-77.

Amabye T. G, Bezabh A. M, Mekonen F. 2016. Phytochemical and antimicrobial potentials leaves extract of Eucalyptus Globulus oil from Maichew Tigray Ethiopia. International Journal of Complementary and Alternative Medicine, 2, 56-59.

AOAC. 2002. Official Methods of Analysis of AOAC International, 17th ed, Association of Office Analysis Chemistry, Gaithersburg, MD, USA 2002.

Batey I.L. 1982. Starch Analysis Using Thermostable Alpha-Amylases. Starch/Stärke, 34, 125-128.

Bosh L, Alegría A, Farre R. 2006. Application of the 6-aminoquinolyl-Nhydroxysccinimidyl carbamate (AQC) reagent to the RP-HPLC determination of amino acids in infant foods. Journal of Chromatography B, 831 (1-2), 176-183.

Carabaño R, Villamide M. J, García J, Nicodemus N, Llorente A, Chamorro S, Menoyo D, García-Rebollar P, García-Ruiz A.I, de Blas J. C. 2009. New concepts and objectives for protein-amino acid nutrition in rabbits, A review. World Rabbit Science, 17, 1-14.

Chaires-Martínez L, Salazar-Montoya J. A, Ramos-Ramírez E. G. 2008. Physicochemical and function characterization of the galactomannan obtained from mesquite seeds (Prosopis Pallida). European Food Research Technology, 227, 1669-1679.

Coudert P, Lebas F, Licois D. 1997. A new pathology devastates the breedings. The profession is mobilized (published in French). Cuniculture, 24, 225-229.

Dakia P. A, Blecker C, Roberta C, Watheleta B, Paquota M. 2008. Composition and physicochemical properties of locust bean gum extracted from whole seeds by acid or water dehulling pre-treatment. Food Hydrocolloids, 22, 807-818. 
Dartois A, Singh J, Kaur L, Singh H. 2010. Influence of guar gum on the in vitro starch digestibility-Rheological and microstructural characteristics. Food Biophysics, 5, 149160.

de Blas C, Mateos C. C. 2010. Feed Formulation. In: Nutrition of the rabbit, de Blas, C, Wiseman, J, Eds. CABI Publishing, Wallingford, UK, 2010, pp. 222-232.

Deshpande P, Mohan V, Thakurdesai P. 2016. Preclinical safety evaluation of low molecular weight galactomannans based standardized fenugreek seeds extract. Experimental and Clinical Sciences Journal, 15, 446.

Edeoga H. O, Okwu D. E, Mbaebie B. O. 2005. Phytochemical constituents of some Nigerian medicinal Plants. African Journal of Biotechnology, 4, 685-688.

European Union. 2010. Directive 2010/63/EU of the European Parliament and of the Council of 22 September 2010 on the protection of animals used for scientific purposes.

Evans W. C. 2009. Trease Evans Pharmacognosy, International Edition E-Book, Elsevier Health Sciences, Amsterdam, The Netherlands.

Falcão-E-Cunha L, Castro-Solla L, Maertens L, Marounek M, Pinheiro V Freire J, Mourão J. L. 2007. Alternatives to antibiotic growth promoters in rabbit feeding. A review. World Rabbit Science, 15, 127-140.

Fernández-Carmona J, Blas E, Pascual J. J, Maertens L, Gidenne T, Xiccato G, García J. 2005. Recommendations and guidelines for applied nutrition experiments in rabbits. World Rabbit Science, 13, 209-228.

Fernández-Carmona J, Jover J, Gutiérrez J. 1993. Características físicas de piensos extrusionados y aceptabilidad por cangrejo rojo (Procambarus clarkii). Archivos de Zootecnia, 42, 219-228.

García J, Gidenne T, Falcão-E-Cunha L, de Blas C. 2002. Identification of the main factors that influence caecal fermentation traits in growing rabbits. Animal Research, 51, 165-173.

Gibbs R. D. 1974. Chemotaxonomy of Flowering Plants, McGill Queen's University Press, Montreal, QC, Canada, London, UK, 1974, Volume 1.

Gibson G. R, Roberfroid M. B. 1995. Dietary modulation of the human colonic microbiota, Introducing the concept of prebiotics. Journal of Nutrition, 125, 1401-1412.

Gidenne T, Arveux P, Madec O. 2001. The effect of the quality of dietary lignocellulose on digestion, zootechnical performance and health of the growing rabbit. Animal Science, $73,97-104$. 
Gidenne T. 1995. Effect of fibre level reduction and gluco-oligosaccharide addition on the growth performance and caecal fermentation in the growing rabbit. Animal Feed Science and Technology, 56, 253-263.

Gidenne, T. 2015. Dietary fibres in the nutrition of the growing rabbit and recommendations to preserve digestive health, A review. Animal, 9, 227-242.

Gidenne T, Carabaño R, García J, de Blas C. 2010. Fibre digestion. In: Nutrition of the Rabbit, de Blas, C, Wiseman, J, Eds, CABI Publishing, Wallingford, UK, 2010, pp. 66-82.

Gómez-Conde M.S, Pérez de Rozas A, Badiola I, Pérez-Alba L, de Blas C, Carabaño R, García J. 2009. Effect of neutral detergent soluble fibre on digestion, intestinal microbiota and performance in twenty-five-day old weaned rabbits. Livestock Science, 125, 192-198.

Harborne, J.B. Phytochemical Methods, Chapman and Hall Ltd., London, UK, 1973, pp. 49188.

Jiang J.X, Zhu L.W, Zhang W.M, Sun R.C. 2007. Characterization of Galactomannan Gum from Fenugreek (Trigonella foenum-graecum) seeds and its rheological properties. International Journal of Polymeric Materials, 56, 1145-1154.

Kakani R. 2013. Prebiotic Properties of Yeast Cell Wall Mannanoligosaccharides and Guar Gum Galactomannans in Starting Broilers. Ph.D. Thesis, Texas A \& M University, College Station, TX, USA, 2013.

Kumar A, Ilavarasn R, Jayachandran T, Decaraman M, Aravindhan P, Padmanaban N, Krishnan M.R.V. 2009. Phytochemical investigation on a tropical plant, Syzygium cumini from Kattuppalayam, Erode district, Tamil Nadu, South India. Pakistan Journal of Nutrition, 8, 83-85.

Lebas F. 1996. Effects of fruct-oligo-saccharides origin on rabbit's growth performance in 2 seasons. In: Proceedings of $6^{\text {th }}$ World Rabbit Congress, Toulouse, France, 9-12 July 1996, 211-215.

Maertens L, Aerts J, De Boever J. 2004. Degradation of dietary oligofructose and inulin in the gastrointestinal tract and the effects on $\mathrm{pH}$ and VFA. World Rabbit Science, 12, 235246.

Majeed M, Majeed S, Nagabhushanam K, Sivakumar A, Sankaran N, Kirankumar B, Furqan A. 2018. Galactomannan from Trigonella Foenum Graecum seed, Prebiotic application and its fermentation by the probiotic Bacillus coagulans strain MTCC 5856. Food Science Nutrition, 6, 666-673. 
Marounek M, Vovk S. J, Benda V. 1997. Fermentation patterns in rabbit caecal cultures supplied with plant polysaccharides and lactate. Acta Veterinaria Brno, 67, 9-13.

Marten G. C, Barnes R. F. 1979. Prediction of energy digestibility of forages with in vitro rumen fermentation and fungal enzyme systems. In: Proceedings of the International Workshop on Standardization of Analytical Methodology for Feeds, Ottawa, ON, Canada, 12-14 March 1979, Pigden W.J, Balch C.C, Graham, M, Eds, International Development Research Centre, Ottawa, ON, Canada, 1980, pp. 61-71.

Mc Cleary B. V. 1988. Carob and guar galactomannans. Methods in Enzymology, 160, 523527.

Morisse J. P, Maurice R, Boilletot E, Cotte J. P. 1992. Assessment of the activity of a fructo oligossaccharides on different caecal parameters in rabbit experimentally infected with E. Coli 0.103. Annales de Zootechnie, 42, 81-87.

Mourão J. L, Alves A, Pinheiro V. 2004. Effects of fructooligosaccharides on performances of growing rabbits. In: Proceedings of the 8th World Rabbit Congress, Puebla, Mexico, 7-10 September 2004, pp. 915-921.

Mourão J. L, Pinheiro V, Alves A, Guedes C. M, Pinto L, Saavedra M. J, Spring P, Kocher A. 2006. Effect of mannan oligosaccharides on the performance, intestinal morphology and cecal fermentation of fattening rabbits. Animal Feed Science and Technology, 126, 107120.

Narayana K, Narsinga-Rao M. S. 1982. Functional properties of raw and heat processed winged bean (Psophocarpus tetragonolobus) flour. Journal of Food Science, 42, 534-538.

Nour A. A. M, Magboul B. I. 1986. Chemical and amino acid composition of fenugreek seeds grown in Sudan. Food Chemistry, 22, 1-5.

Ocasio-Vega C, Abad-Guamán R, Delgado R, Carabaño R, Dolores Carro M, García J. 2018. Effect of cellobiose supplementation and dietary soluble fibre content on in vitro caecal fermentation of carbohydrate-rich substrates in rabbits. Archive of Animal Nutrition, 72, 1477-2817.

Owusu-Asiedu A. J. F. J, Patience J. F, Laarveld B, Van Kessel A. G, Simmins P. H, Zijlstra R. T. 2006. Effects of guar gum and cellulose on digesta passage rate, ileal microbial populations, energy and protein digestibility, and performance of grower pigs. Journal of Animal Science, 84, 843-852.

Peeters J. E, Maertens L, Geeroms R. 1992. Influence of galacto-oligosaccharides in zootechnical performance, cecal biochemistry and experimental Colibacillosis o103/8+ in weanling rabbits. Journal of Applied Rabbit Research, 15, 1129-1136. 
Piquer O, Casado C, Biglia S, Fernández C, Blas E, Pascual J. J. 2009. In vitro gas production kinetics of whole citrus fruits. Journal of Animal Feed Science, 18, 743-757.

Plummer, D. T. Practical Biochemistry, McGraw Hill Book Company, London, UK 1971.

Ramos M, Carabaño R. 1996. Nutritive evaluation of rabbit diets by an in vitro method. In: Proceedings of the 6th World Rabbit Congress, Toulouse, France, 9-12 July 1996, pp. 277282.

Rizk A. M, AM R, Al Nagdy S. A, El Missiry M. M. 1982. Constituents of plant growing in Qatar. Fitoterapia, 52, 35-42.

Roberfroid M.B. 2007. Prebiotics, The Concept Revisited. Journal of Nutrition, 137, 830837.

Robertson J. B, Van Soest P. J. 1981. The detergent system analysis and its application to human foods in the analysis of dietary fibre food. In: The Analysis of Dietary Fibre in Food, James, W.P.T, Theander, J. Eds, Marcel Dekker, New York, NY, USA, pp. 123-157.

Rosell J. M, de la Fuente L. F, Badiola J. I, Fernández de Luco D, Casal J, Saco M. 2009. Study of urgent visits to commercial rabbit farms in Spain and Portugal during 19972007. World Rabbit Sci. 17, 127-136.

Statistical Analysis Software (SAS). 2009. SAS/STAT User's Guide (Release 9.2). SAS Institute Inc, Cary, NC, USA, 2009.

Schofield P, Pitt R. E, Pell A.N. 1994. Kinetics of fibre digestion from in vitro gas production. Journal of Animal Science, 72, 2980-2991.

Schofield, P. 2000. Gas production methods. In: Farm Animal Metabolism and Nutrition; D'Mello, J. P. F. Ed, CABI Publishing, Wallingford, UK, 2000, pp. 209-232.

Torio M. A. O, Saez J, Merca F. E. 2006. Physicochemical characterization of galactomannan from sugar palm (Arenga Saccharifera Labill.) endosperm at different stages of nut maturity. Philippine Journal of Science, 135, 19-30.

Trocino A, García J, Carabaño R, Xiccato G. A. 2013a. meta-analysis of the role of soluble fibre in diets for growing rabbits. World Rabbit Science, 21, 1-15.

Trocino A, Fragkiadakis, M, Majolini D, Tazzoli M, Radaelli G, Xiccato G. 2013b. Soluble fibre, starch and protein level in diets for growing rabbits, Effects on digestive efficiency and productive traits. Animal Feed Science and Technology, 180, 73-82.

Van Nevel C. J, Decuypere J. A, Dierick N. A, Koen Molly K. 2005. Incorporation of galactomannans in the diet of newly weaned piglets, Effect on bacteriological and some 
morphological characteristics of the small intestine. Archive of Animal Nutrition, 59, 123138.

Van Soest P. J. Mathematical applications, Digestibility. In: Nutritional Ecology of the Ruminant, 2nd ed, Comstock Publishing Associates, Ithaca, NY, USA, 1994, pp. 354-370.

Van Soest P. J, Robertson J. B, Lewis B. A. 1991. Methods for dietary fibre, neutral detergent fibre, and non-starch polysaccharides in relation to animal nutrition. Journal of Dairy Science, 74, 3583-3597.

Volek Z, Marounek M. 2011. Dried chicory root (Cichorium intybus L.) as a natural fructan source in rabbit diet, Effects on growth performance, digestion and caecal and carcass traits. World Rabbit Science, 19, 143-150.

Wang J. T, Li D. F, Gong L. M, Cheng G. 2003. Effect of galactomannan-oligosaccharides on the growth performance and immune function in broilers. Chinese Journal of Animal Science, 39, 5-6.

Zemzmi J, Mabrouki S, Abdouli H, Najar T. 2017. Preliminary characterization of fenugreek seed gum for use as prebiotic in rabbits' nutrition. In: Proceedings of the 20th International Symposium on Housing and Diseases of Rabbits, Fur Providing Animals and Pet Animals, Celle, Germany, 17-18 May 2017, pp. 179-186. 


\section{Chapter III}

Effect of fenugreek seed gum dietary supply in conventional rabbit diet and low digestive risk diet on in vivo performance, nutrient digestibility and caecal environment of growing rabbits

Zemzmi J'23, Ródenas L², Blas E², Martínez-Paredes E², Najar T², Pascual J.J²

${ }^{1}$ Laboratory of Improvement \& Integrated Development of Animal Productivity \& Food Resources, Higher School of Agriculture of Mateur, University of Carthage, Route de Tabarka, 7030, Mateur,Tunisia Republic

2Institute for Animal Science and Technology, Universitat Politècnica de València, Camino de Vera, s/n, 46022, Valencia, Spain

${ }^{3}$ National Agronomic Institute of Tunisia, University of Carthage, Avenue de la République BP 77-1054, Amilcar, Tunisia Republic 


\section{Abstract}

The aim of this work was to determine the prebiotic potential of the dietary inclusion of $10 \mathrm{~g} / \mathrm{kg}$ of fenugreek seed gum (FSG) evaluating its effect on overall health state, growth performance, nutrient digestibility and caecal characteristics of growing rabbits. Four diets were formulated according a 2 × 2 factorial design, a conventional rabbit diet (C) with 104 and $156 \mathrm{~g} / \mathrm{kg}$ DM of soluble fibre (SF) and crude protein $(\mathrm{CP})$, respectively; a C diet supplemented with $10 \mathrm{~g} / \mathrm{kg}$ of FSG (CFSG); a low risk diet (LR) with 205 and $121 \mathrm{~g} / \mathrm{kg}$ DM of SF and CP, respectively; and a LR diet supplemented with $10 \mathrm{~g} / \mathrm{kg}$ of FSG (LRFG). Two hundred and sixteen crossbred rabbits of LP line weaned at 28 days of age were randomly allocated in individual cages, providing free access to water and one of the 4 experimental diets. Mortality, morbidity, health risk index (HRi), daily feed intake (DFI), average daily gain (ADG) and feed conversion ratio (FCR) were controlled until 63 days of age. Coefficient of total tract apparent digestibility (CTTAD) of nutrients on 12 rabbits per treatment was determined from 49 to 53 days of age. Caecal environment was evaluated at 63 days old. FSG dietary inclusion at $10 \mathrm{~g} / \mathrm{Kg}$ did not affect health and growth performance traits nor CTTAD of main nutrients, although slightly higher CTTAD of neutral detergent fibre (NDF) and acid detergent fibre (ADF) were observed in CFsG respect to C groups $(+0.033$ and +0.018 , respectively; $\mathrm{P}<0.10)$. Dietary inclusion of FSG only increased caecal caproic acid proportions of rabbits fed with the conventional

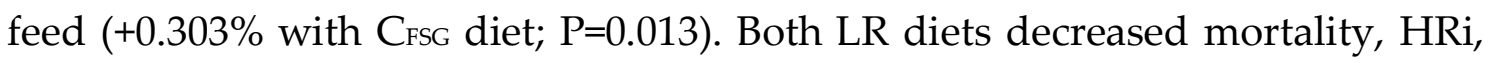
DFI, ADG and CTTAD of DM, organic matter and CP $(-16.9 \%,-12.5 \%,-10.0 \mathrm{~g}$ $\mathrm{DM} / \mathrm{d},-9.8 \mathrm{~g} / \mathrm{d},-0.026,-0.017$ and -0.119 , respetively; $\mathrm{P}<0.05)$, but increased FCR and CTTAD of NDF and ADF $(+0.48,+0.099$ and +0.128 , respectively; $\mathrm{P}<0.05)$ in comparison to $\mathrm{C}$ diets. Respect to caecal traits, LR diets increased caecal VFA production and proportion of acetic, isobutyric and isovaleric acids $(+9.4$ $\mathrm{mmol} / \mathrm{L},+3.4 \%,+0.078 \%$ and $+0.081 \%$, respectively; $\mathrm{P}<0.001)$ and decreased 
caecal DM, N-NH 3 and proportion of butyric, caproic and valeric acids $(-31 \mathrm{~g} / \mathrm{kg}$, $-58.9 \mathrm{mg} / \mathrm{L},-3.2 \%,-0.582 \%$ and $-0.277 \%$, respectively; $\mathrm{P}<0.001)$. In conclusion, dietary inclusion of $10 \mathrm{~g} / \mathrm{kg}$ of FSG did not produce any significant effect on health, growth, nutrients digestibility and caecal environment of growing rabbit, being advisable to evaluate higher level of inclusion in future works. Until then, low risk diets, based on higher SF and lower $\mathrm{CP}$, could contribute to reduce the risk of digestible problems at expenses of a reduced growth.

Key words, fenugreek seed gum, rabbit, soluble fibre, crude protein, digestive health.

\section{Implications}

Post-weaning mortality remains the biggest concern of the rabbit's breeders. Even in best farm conditions, antibiotic use remains indispensable to resolve this situation. Increasing dietary fibre and protein content showed to have a positive impact on the digestive health of rabbits. However, dietary inclusion of fenugreek seed gum, as a prebiotic, although could modulate caecal environment did not affect rabbits' health under an outbreak of epizootic rabbit enteropathy. Further studies on the use of prebiotic potentials for the rabbit should be carried out to reduce dependence on the use of antibiotics and improve rabbit performance.

\section{Introduction}

The second week after weaning is the most critical period for the meat rabbit production cycle being that, its digestive system is considered in a non-stable balance (Bovera et al., 2010). Factors such as separation from the mother, cage changing and especially milk deprivation increase the susceptibility of postweaning digestive disorders. The most frequent digestive disorder during the growing period is the occurrence of the epizootyc rabbit enteropathy (ERE) (Licois et al., 2006; Bäuerl et al., 2014; Badiola et al., 2016). ERE is the prime cause of mortality in the European rabbit industry (Dewree et al., 2003) and the most 
worrying is that there is no identified pathogenic agent today (Licois et al., 2006; Marlier et al., 2006; Szalo et al., 2007; Huybens et al., 2009).

A balanced supply of low and high digestible fibre fractions and replacing a part of the starch with digestible fibre fractions are recommended. Many studies support this strategy, reporting improvement in the health risk index (HRi) but weakly modification of feed efficiency (Perez et al., 2000; Tazzoli et al., 2009; Trocino et al., 2011). Moreover, reduction of dietary protein content usually led to a significant improvement in the digestive health status of the growing rabbit without significant impairment of growth performance (Xiccato et al., 2011; Gidenne et al., 2013). In fact, when dietary crude protein (CP) content was over $160 \mathrm{~g} / \mathrm{kg}$, many studies has reported high mortality rates associated to ERE (Bovera et al., 2010 and 2012; Ocasio-Vega et al., 2018 and 2019). Accordingly, reducing $\mathrm{CP}$ and increasing digestible fibre levels in growing rabbit diets, respecting certain levels that do not worsen animal's performance, might be a beneficial combination for better rabbit breeding.

On the other hand, some natural gums are considered to be potential substrates for probiotic bacteria such as bifidobacteria, lactobacilli and lactococci (Mudgil et al., 2018; Salavati-Schmitz and Allenspach, 2017). In previous studies (Zemzmi et al., 2020a,b), galactomannan from fenugreek seed gum (FSG) demonstrated the two principle conditions defining a feed ingredient as a prebiotic, which are resistance to pre-caecum digestion and high fermentability once reach the caecum. FSG seems to affect caecal microbiota in rabbits. In fact, in vitro enzymatic digestion of FSG reduced caecal $\mathrm{pH}$, lactate and nitrogen ammonia $\left(\mathrm{N}_{-} \mathrm{NH}_{3}\right)$ concentrations (Zemzmi et al., 2020a), and increased propionate, isobutyrate and isovalerate proportions and reduced that of caproate (Zemzmi et al., 2020b). In addition, FSG inclusion in rabbits diets seems to increase neutral detergent fibre (NDF) and acid detergent fibre (ADF) faecal digestion (Zemzmi et al., 2020a). However, in vivo supplementation of FSG up to $5 \mathrm{~g} / \mathrm{kg}$ in a 
commercial antibiotic-free diet only produced little relevant changes on health status and caecal activity in growing rabbits (Zemzmi et al., 2020a).

Nevertheless, it is unknown what in vivo results could be obtained with the supplementation of this prebiotic at a higher concentration in growing rabbit diets, and its possible interactions with the type of diet used. Only Ocasio-Vega et al. (2018 and 2019) observed that the response of animals to dietary supplementation with a potential prebiotic, such as cellobiose, was completely different depending on the soluble fibre content of the diet used. Our hypothesis was that the synergy of high digestible fibre and low protein diet with dietary supplementation of fenugreek seed gum (FSG), rich in galactomannans as a functional food ingredient with a prebiotic effect, might improve the digestive health statue of growing rabbit in an antibiotic-free diet. The aim of this work was to evaluate the effect of FSG supplementation both in conventional and lowrisk diets on in vivo performance, nutrient digestibility and caecal fermentation of growing rabbits after weaning.

\section{Materials and methods}

Diets

Four experimental diets were formulated and pelleted according to a $2 \times 2$ factorial design (Table 1), conventional diet (C), following the current recommendations of de Blas and Mateos (2010) for growing rabbits, with 104 and $156 \mathrm{~g} / \mathrm{kg}$ DM of soluble fibre (SF) and CP, respectively; C diet supplemented with $10 \mathrm{~g} / \mathrm{kg}$ of FSG (CFsG); low-risk diet (LR), with 205 and $121 \mathrm{~g} / \mathrm{kg}$ DM of SF and CP, respectively; and LR diet supplemented with $10 \mathrm{~g} / \mathrm{kg}$ of FSG (LRFSG).

FSG was extracted according to the protocol of Zemzmi et al. (2017), where the seeds of fenugreek were grounded to pass a $2 \mathrm{~mm}$ of diameter, defatted in hexane-isopropanol $(3 / 2, v / v)$, extracted in distilled water for $24 \mathrm{~h}$ and precipitated with ethanol $95^{\circ} \mathrm{C}$. Then, the FSG extracted was washed with acetone, and finally freeze-dried and grounded obtaining a white powder. FSG 
has $898.2 \mathrm{~g} \mathrm{DM}, 12.7 \mathrm{~g}$ ash, $267.8 \mathrm{~g} \mathrm{CP}$ and $590 \mathrm{~g}$ galactose and mannose per $\mathrm{kg}$ DM.

\section{Animals}

The experimental protocols followed both the Spanish Royal Decree 53/2013 on the protection of animals used for scientific purposes (Boletín Oficial del Estado, 2013) and the recommendation for applied nutrition research in rabbits described by the European Group on Rabbit Nutrition (Fernández-Carmona et al., 2005), being approved by the committee of Ethics and Animal Welfare of the Universidad Politècnica de Valencia (research code, 2018/VSC/PEA/0116). Twohundred and sixteen rabbits, weaned at 28 days of life, from the LP line of the Polytechnic University of Valencia, were randomly assigned to the four experimental groups (C, CFSG, LR and LRFSG) blocking by the litter origin. Animals were housed in individual cages $(52 \times 44 \times 32 \mathrm{~cm})$ from weaning to the end of the experiment period (63 days of age), were fed ad libitum and had free access to water. Temperature (from $16^{\circ} \mathrm{C}$ to $24^{\circ} \mathrm{C}$ ) and photoperiod $(12 \mathrm{~h}$ of light and $12 \mathrm{~h}$ of darkness) of the experimental farm were controlled during the trial. Mortality and morbidity were daily recorded. Daily feed intake (DFI), average daily gain (ADG) and feed conversion ratio (FCR) were weekly controlled.

\section{Chemical analysis}

Methods of the AOAC (2002) were used to determine DM (934.01), ash (942.05), CP (990.03, Dumas method, CN628 Elemental Analyzer, LECO, St. Joseph, MI, USA) and ether extract (920.39, with acid-hydrolysis of samples prior to the extraction). Starch content was determined according to Batey (1982), by a twostep enzymatic procedure with solubilisation and hydrolysis to malto dextrins with thermo-stable $\alpha$-amylase followed by complete hydrolysis with amyloglucosidase (both enzymes from Sigma-Aldrich, Steinheim, Germany), and the resulting D-glucose being measured by the hexokinase/glucose-6 phosphate dehydrogenase/NADP system (kit D-glucose-HK Megazyme Int. 
Ireland Ltd, Wicklow, Ireland). The total dietary fibre (TDF) content was determined by a gravimetric-enzymatic method, the procedure 991.43 of the Van Soest et al. (1991), with $\alpha$-amylase, protease and amyloglucosidase treatments (Megazyme TDF R.30.K-TDFR-100A/200A), correcting for ash and CP. NDF, ADF and ADL fractions were analysed sequentially according to Mertens (2002), procedure 973.18 of the AOAC (2002) and Robertson and Van Soest (1981), respectively, with a thermo-stable $\alpha$-amylase pre-treatment and expressed exclusive of residual ash, by using a nylon filter bag system (Ankom, Macedon, NY, USA). The SF content was determined as proposed by Van Soest et al. (1991), by subtracting the NDF corrected for CP from the TDF content. Determination of VFA was based on the method described by Jouany (1982). Samples were filtered through $0.45 \mu \mathrm{m}$ cellulose syringe filters. Next, $100 \mu \mathrm{L}$ of an internal standard solution (0.4 g of 4-methylvaleric acid diluted in $100 \mathrm{~mL}$ of deionised water) and $0.1 \mathrm{~mL}$ of a preservative $\left(5 \% \mathrm{H}_{3} \mathrm{PO}_{4}\right.$ and $1 \% \mathrm{HgCl}_{2}$ in deionised water) were added to $0.9 \mathrm{~mL}$ of filtrate. One $\mu \mathrm{L}$ from each sample was injected in a gas chromatograph (Fisons 8000 series, Milan, Italy) equipped with a split/split less injector and FID detector. The separation of VFA was made in a DB-FFAP capillary column $(30 \mathrm{~m} \times 0.25 \mathrm{~mm} \times 0.25 \mu \mathrm{m}$ of film thickness, J\&W Scientific, Folson, CA, USA). The carrier gas was $\mathrm{N}_{2}$ at a constant pressure of $120 \mathrm{kPa}$. Injector and detector temperatures were set at $200^{\circ} \mathrm{C}$ and $245^{\circ} \mathrm{C}$ respectively. The initial oven temperature was set at $110{ }^{\circ} \mathrm{C}$ held for $5 \mathrm{~min}$ and increased to $230{ }^{\circ} \mathrm{C}$ at $8.5^{\circ} \mathrm{C} / \mathrm{min}$ and finally maintained at that temperature for $10 \mathrm{~min}$. Finally, VFA were identified by comparing their retention times with a standard (46975-U from Supelco ${ }^{\circledR}$, Bellefonte, PA, USA). Then caecal N-NH3 was analysed using Kjeldhal method (976.05) for determination and calculation of nitrogen content (reference number 5983) and its concentration was expressed as $\mathrm{mg} / \mathrm{L}$ of caecal content. 
Table 3.1. Ingredients $(\mathrm{g} / \mathrm{kg})$ and chemical composition $(\mathrm{g} / \mathrm{kg} \mathrm{DM})$ of the experimental diets.

\begin{tabular}{|c|c|c|}
\hline & \multicolumn{2}{|c|}{ Diets } \\
\hline & $\mathrm{C}^{1}$ & $\mathrm{LR}^{2}$ \\
\hline \multicolumn{3}{|l|}{ Ingredients } \\
\hline Wheat & 14.00 & 4.30 \\
\hline Wheat bran & 24.00 & 27.00 \\
\hline Soya meal $(44 \% \mathrm{CP})$ & 8.90 & 10.60 \\
\hline Alfalfa hay & 8.50 & 0.00 \\
\hline Oat hulls & 2.50 & 2.50 \\
\hline Grape pomace & 10.90 & 9.20 \\
\hline Defatted grape seeds & 3.00 & 7.00 \\
\hline Cereal straw & 12.00 & 5.00 \\
\hline Beet pulp & 4.00 & 27.00 \\
\hline Soya oil & 4.00 & 0.00 \\
\hline Corn starch & 5.20 & 5.20 \\
\hline L-lysine $\mathrm{HCl}$ & 0.19 & 0.00 \\
\hline D-Methionine & 0.055 & 0.01 \\
\hline L-Threonine & 0.14 & 0.05 \\
\hline Calcium carbonate & 0.85 & 0.59 \\
\hline Dicalcium phosphate & 0.62 & 0.55 \\
\hline Sodium chloride & 0.325 & 0.400 \\
\hline Sodium bicarbonate & 0.32 & 0.10 \\
\hline Vitamin-trace elements premix ${ }^{3}$ & 0.50 & 0.50 \\
\hline \multicolumn{3}{|l|}{ Chemical composition } \\
\hline Dry matter (DM, g/kg) & 914 & 919 \\
\hline Ash & 82.2 & 80.0 \\
\hline Crude protein $(\mathrm{CP})$ & 156 & 121 \\
\hline Ether extract & 52 & 20 \\
\hline Neutral detergent fibre & 373 & 444 \\
\hline Acid detergent fibre & 194 & 250 \\
\hline Lignin acid detergent & 52 & 78 \\
\hline Cellulose $^{4}$ & 179 & 194 \\
\hline Hemicellulose $^{5}$ & 142 & 172 \\
\hline Total dietary fibre & 401 & 570 \\
\hline Soluble fibre ${ }^{6}$ & 104 & 205 \\
\hline Starch & 199 & 144 \\
\hline
\end{tabular}

${ }^{1}$ Conventional rabbit diet; 2 Low risk diet, with higher soluble fibre and lower protein dietary content; ${ }^{3}$ Contains per kg of feed, vitamin A, $8375 \mathrm{IU}$; vitamin D3, $750 \mathrm{IU}$; vitamin E, $20 \mathrm{mg}$; Vitamin K3, $1 \mathrm{mg}$; vitamin B1, $1 \mathrm{mg}$; vitamin B2, $2 \mathrm{mg}$; vitamin B6, $1 \mathrm{mg}$; nicotinic acid, $20 \mathrm{mg}$; choline chloride, $250 \mathrm{mg}$; magnesium, $290 \mathrm{mg}$; manganese, $20 \mathrm{mg}$; zinc, $60 \mathrm{mg}$; iodine, $1.25 \mathrm{mg}$; iron, $26 \mathrm{mg}$; copper, $10 \mathrm{mg}$; cobalt, $0.7 \mathrm{mg}$; butyl hydroxylanysole and ethoxiquin mixture, $4 \mathrm{mg} .{ }^{4}$ Cellulose, as neutral detergent fibre-acid detergent fibre; ${ }^{5} \mathrm{Hemicellulose}$, as acid detergent fibre-lignin detergent fibre; ${ }^{6}$ Soluble fibre, as total dietary fibre-neutral detergent fibre. 


\section{Statistical analysis}

Data were analysed using SAS software (Statistical Analysis Systems Institute, 2009). Mortality, morbidity and the health risk indexes were analysed according to a generalized linear model (GENMOD procedure for binomial distribution) including the diet, FSG inclusion and their interaction as main effects in the model, and the results were transformed from the logit scale. Data from apparent faecal digestibility and caecal activity were analysed with a general linear model (GLM procedure) considering the diet, FSG inclusion and their interaction as main effects. Data from growth performance were analysed according to the mixed model (MIXED procedure) considering the diet, FSG inclusion, growing week and their interaction as main effects. Random terms in the model included a permanent effect of each animal (p) and the error term (e), both assumed to have an average of zero, and variance $\sigma^{2} \mathrm{p}$ and $\sigma^{2} \mathrm{e}$. Results were presented as least square means with their standard errors. Statistical significance level was set at $5 \%(0.05)$.

\section{Results}

Dietary supplementation of $10 \mathrm{~g} / \mathrm{kg}$ of FSG did not affect significantly the mortality rate, morbidity and HRi (Table 3.2). However, both LR diets reduced the mortality rate respect to $\mathrm{C}$ diets (on av. $-16.9 \pm 0.32 \%, \mathrm{P}=0.017$ ) but effect on morbidity rate and the HRi was not significant. No interaction between diet and FSG on health traits was observed.

Table 3.3 shows the effect of dietary treatments on nutrients digestibility. Feed intake during the digestibility trial was that expected for growing rabbits from 49 to 56 days of age (on av. $95.2 \pm 3.0 \mathrm{~g} / \mathrm{d}$ ), although slightly higher in C diets than in LR diets $(+6.7 \pm 2.976 \mathrm{~g} / \mathrm{d} ; \mathrm{P}=0.031)$. Dietary supplementation of FSG did not significantly affected any CTTAD coefficient. However, both LR diets showed lower CTTAD of DM, OM and CP $(-0.025 \pm 0.008,-0.017 \pm 0.008$ and $-0.119 \pm 0.012$, respectively; $\mathrm{P}<0.05)$ but higher $\mathrm{CTTAD}$ of $\mathrm{NDF}$ and $\mathrm{ADF}$ than both $\mathrm{C}$ diets 
$(+0.099 \pm 0.013$ and $0.127 \pm 0.017$ respectively, $\mathrm{P}<0.001)$. No interaction between diet and FSG on CTTAD traits was observed.

Table 3.2 Effect the dietary treatment on mortality, morbidity rate and health risk index of the growing rabbits.

\begin{tabular}{lccccccc}
\hline & \multicolumn{3}{c}{ Diets } & & p-value \\
\cline { 2 - 8 } & C & CFSG & LR & LRFSG & Diet & FSG & Diet $\times$ FSG \\
\hline Number of rabbits & 55 & 58 & 51 & 52 & & & \\
Mortality rate (\%) & $41.8^{\mathrm{ab}}$ & $46.5^{\mathrm{b}}$ & $23.5^{\mathrm{a}}$ & $32.7^{\mathrm{ab}}$ & 0.017 & 0.277 & 0.631 \\
Morbidity rate (\%) & 10.9 & 5.2 & 9.8 & 13.5 & 0.745 & 0.859 & 0.202 \\
HRi (\%) & $52.7^{\mathrm{b}}$ & $51.7^{\mathrm{ab}}$ & $33.3^{\mathrm{a}}$ & $46.2^{\mathrm{ab}}$ & 0.072 & 0.224 & 0.285 \\
\hline
\end{tabular}

FSG, fenugreek seeds gum; C, conventional diet; CFSG, conventional diet supplemented with 1\% of FSG; LR, low risk diet; LRFSG, low risk diet supplemented with 1\% of FSG; SEM, pooled standard error of the mean; HRi, health risk index as mortality + morbidity; a,b means within a row not sharing superscript are significant different at $\mathrm{P}<0.05$.

Initial body weight was similar for the four experimental groups (on av. 540 \pm 16 g; Table 3.4). Dietary supplementation of $10 \mathrm{~g} / \mathrm{Kg}$ of FSG did not significantly affect DFI, ADG, FCR and final BW of growing rabbits. Respect to the effect of diet, animals feed with both LR diets showed lower DFI and ADG (-10.0 $2.6,-$ 9.9 $\pm 0.6 \mathrm{~g} / \mathrm{d}$, respectively; $\mathrm{P}<0.001)$, but higher FCR $(+0.48 \pm 0.05 ; \mathrm{P}<0.001)$, reaching 63 days of age with a lower BW than those fed with C diets $(-347 \pm 22 \mathrm{~g} ; \mathrm{P}<0001)$.

Table 3.3 Effect of dietary treatments on nutrients digestibility of growing rabbits (49 to 56 days of age)

\begin{tabular}{lcccccccc}
\hline & \multicolumn{4}{c}{ Diets } & \multicolumn{4}{c}{ p-value } \\
\cline { 2 - 9 } & $\mathrm{C}$ & CFSG & LR & LRFSG & SEM & Diet & FSG & Diet $\times$ FSG \\
\hline Feed intake (g DM/day) & 97.7 & 99.3 & 92.7 & 90.9 & 3.0 & 0.031 & 0.946 & 0.564 \\
Coefficients of total tract apparent digestibility & & & & & \\
$\quad$ Dry matter & $0.561^{\mathrm{b}}$ & $0.558^{\mathrm{b}}$ & $0.534^{\mathrm{a}}$ & $0.534^{\mathrm{a}}$ & 0.008 & 0.004 & 0.855 & 0.838 \\
Organic matter & $0.561^{\mathrm{b}}$ & $0.555^{\mathrm{ab}}$ & $0.540^{\mathrm{a}}$ & $0.542^{\mathrm{ab}}$ & 0.008 & 0.044 & 0.792 & 0.669 \\
Crude protein & $0.667^{\mathrm{b}}$ & $0.642^{\mathrm{b}}$ & $0.541^{\mathrm{a}}$ & $0.530^{\mathrm{a}}$ & 0.012 & $<0.001$ & 0.141 & 0.547 \\
Neutral detergent & & & & & & & & \\
fibre & $0.201^{\mathrm{a}}$ & $0.234^{\mathrm{a}}$ & $0.314^{\mathrm{b}}$ & $0.319^{\mathrm{b}}$ & 0.013 & $<0.001$ & 0.139 & 0.547 \\
Acid detergent fibre & $0.056^{\mathrm{a}}$ & $0.074^{\mathrm{a}}$ & $0.199^{\mathrm{b}}$ & $0.186^{\mathrm{b}}$ & 0.017 & $<0.001$ & 0.912 & 0.368 \\
\hline
\end{tabular}

FSG, fenugreek seeds gum; C, conventional diet; CFSG, conventional diet supplemented with 1\% of FSG; LR, low risk diet; LRFSG, low risk diet supplemented with 1\% of FSG; SEM, pooled standard error of the mean; $\mathrm{a}, \mathrm{b}$ means within a row not sharing superscript are significant different at $\mathrm{P}<0.05$. 
Table 3.4 Effect of dietary treatments on growth performance of growing rabbits (28 to 63 days of age).

\begin{tabular}{|c|c|c|c|c|c|c|c|c|}
\hline & \multicolumn{4}{|c|}{ Diets } & \multirow[b]{2}{*}{ SEM } & \multicolumn{3}{|c|}{$\mathrm{p}$-value } \\
\hline & $\mathrm{C}$ & CFSG & LR & LRFSG & & Diet & FSG & Diet $\times$ FSG \\
\hline Initial BW (g) & 533 & 538 & 541 & 549 & 16 & 0.480 & 0.630 & 0.943 \\
\hline DFI (g DM/day) & $84.5^{\mathrm{bc}}$ & $86.3^{c}$ & $76.1^{\mathrm{ab}}$ & $74.7^{\mathrm{a}}$ & 2.6 & $<0.001$ & 0.939 & 0.494 \\
\hline ADG (g/day) & $35.2^{\mathrm{b}}$ & $36.1^{\mathrm{b}}$ & $26.2^{\mathrm{a}}$ & $25.4^{\mathrm{a}}$ & 0.6 & $<0.001$ & 0.916 & 0.115 \\
\hline FCR & $2.42^{b}$ & $2.46^{\mathrm{b}}$ & $2.91^{\mathrm{a}}$ & $2.93^{a}$ & 0.05 & $<0.001$ & 0.610 & 0.803 \\
\hline Final BW (g) & $1752^{\mathrm{b}}$ & $1784^{\mathrm{b}}$ & $1435^{a}$ & $1407^{a}$ & 22 & $<0.001$ & 0.496 & 0.831 \\
\hline
\end{tabular}

BW, body weight; DFI, daily feed intake; ADG, average daily gain; FCR, feed conversion ratio; FSG, fenugreek seeds gum; C, conventional diet; CFSG, conventional diet supplemented with $1 \%$ of FSG; LR, low risk diet; LRFsG, low risk diet supplemented with $1 \%$ of FSG; SEM, pooled standard error of the mean; a,b,c means within a row not sharing superscript are significant different at $\mathrm{P}<0.05$.

From 28 to 35 days of age, animals of LRFsG group showed higher DFI and FCR than those of LR group $(+6.2 \pm 2.2 \mathrm{~g} / \mathrm{d},+0.58 \pm 0.08 ; \mathrm{P}<0.05$; Figure 3.1$)$. In the contrary, animals of LR group showed higher DFI than those of LRFS group from 56 to 63 days of age $(+8.2 \pm 2.2 \mathrm{~g} / \mathrm{d}, \mathrm{P}=0.005$ Figure 3.1). From 42 to 49 days of age, animals fed with CFsG diet had higher DFI and ADG than those fed with C diet $(+6.9 \pm 2.3$ and $+3.9 \pm 1.2 \mathrm{~g} / \mathrm{d} ; \mathrm{P}<0.05$; Figure 3.1). Finally, from 49 to 56 days of age, animals fed with CFSG diet showed lower ADG and higher FCR $(-3.6 \pm 1.2 \mathrm{~g} / \mathrm{d}$ and $+0.40 \pm 0.08$, respectively; $\mathrm{P}<0.05$; Figure 3.1) than those fed with $\mathrm{C}$ diet.

Table 3.5. Effect of dietary treatments on caecal traits of growing rabbits at $63 \mathrm{~d}$ of age.

\begin{tabular}{|c|c|c|c|c|c|c|c|c|}
\hline & \multicolumn{4}{|c|}{ Diets } & \multicolumn{4}{|c|}{$\mathrm{P}$-value } \\
\hline & C & $\mathrm{CFSG}_{\mathrm{FSG}}$ & LR & $\mathrm{LR}_{\mathrm{FSG}}$ & SEM & Diet & FSG & Diet x FSG \\
\hline Caecal DM (g/kg) & $23.82^{b}$ & $23.88^{\mathrm{b}}$ & $21.07^{a}$ & $20.42^{a}$ & 0.316 & $<0.001$ & 0.294 & 0.198 \\
\hline Caecal pH & 5.87 & 5.88 & 5.83 & 5.83 & 0.03 & 0.095 & 0.736 & 0.777 \\
\hline Caecal VFA (mmol/L) & $42.9^{a}$ & $41.9^{a}$ & $51.7 \mathrm{~b}$ & $51.9^{\mathrm{b}}$ & 2.0 & $<0.001$ & 0.869 & 0.732 \\
\hline VFA profile ( $\%$ of total V & & & & & & & & \\
\hline Acetic acid & $75.4^{\mathrm{a}}$ & $75.2^{\mathrm{a}}$ & $78.3^{\mathrm{b}}$ & $79.1^{\mathrm{b}}$ & 0.7 & $<0.001$ & 0.607 & 0.419 \\
\hline Propionic acid & 4.11 & 4.06 & 4.43 & 4.45 & 0.17 & 0.019 & 0.912 & 0.811 \\
\hline Butyric acid & $18.4^{\mathrm{b}}$ & $18.3^{\mathrm{b}}$ & $15.4^{a}$ & $14.9^{a}$ & 0.6 & $<0.001$ & 0.582 & 0.643 \\
\hline Isobutyric acid & $0.144^{\mathrm{ab}}$ & $0.155^{\mathrm{a}}$ & $0.206^{\mathrm{b}}$ & $0.249 \mathrm{~b}$ & 0.018 & $<0.001$ & 0.096 & 0.320 \\
\hline Caproic acid & $0.946^{\mathrm{b}}$ & $1.249^{c}$ & $0.528^{a}$ & $0.504^{a}$ & 0.064 & $<0.001$ & 0.013 & 0.004 \\
\hline Valeric acid & $0.729 \mathrm{~b}$ & $0.718^{\mathrm{b}}$ & $0.448^{\mathrm{a}}$ & $0.446^{\mathrm{a}}$ & 0.028 & $<0.001$ & 0.780 & 0.826 \\
\hline Isovaleric acid & $0.191^{\mathrm{a}}$ & $0.187 \mathrm{a}$ & $0.254^{\mathrm{b}}$ & $0.285^{\mathrm{b}}$ & 0.018 & $<0.001$ & 0.397 & 0.262 \\
\hline Propionic/acetic ratio & 0.055 & 0.054 & 0.057 & 0.057 & 0.002 & 0.247 & 0.836 & 0.979 \\
\hline Caecal N-NH $3(\mathrm{mg} / \mathrm{L})$ & $106.7 \mathrm{~b}$ & $115.8^{\mathrm{b}}$ & $52.2^{\mathrm{a}}$ & $52.6^{a}$ & 9.7 & $<0.001$ & 0.593 & 0.610 \\
\hline
\end{tabular}

VFA, volatile fatty acids; FSG, fenugreek seeds gum; C, conventional diet; CFSG, conventional diet supplemented with $1 \%$ of FSG; LR, low risk diet; LRFsG, low risk diet supplemented with 1\% of FSG; SEM, pooled standard error of the mean; ${ }^{a, b, c}$ means within a row not sharing superscript are significant different at $\mathrm{P}<0.05$. 
Finally, Table 3.5 shows the effect of dietary treatment on caecal traits of growing rabbits at 63 days of age. Compared to C diets, both LR diets induced lower DM and $\mathrm{N}-\mathrm{NH}_{3}(-31 \pm 0.31 \mathrm{~g} / \mathrm{kg}$ and $-58.9 \pm 9.7 \mathrm{mg} / \mathrm{L}$, respectively; $\mathrm{P}<0.001)$, but higher total VFA content in the caecal content $(+9.4 \pm 2.0 \mathrm{mmol} / \mathrm{L}, \mathrm{P}<0.001)$. Moreover, LS diets increased the molar proportions of acetic, propionic, isobutiric and isovaleric acids $(+3.40 \pm 0.69,+0.36 \pm 0.17,+0.08 \pm 0.02$ and $+0.08 \pm 0.02 \%$ of total VFA, respectively; $\mathrm{P}<0.001)$, but decreased butyric, caproic and valeric acid in the caecum $(-3.20 \pm 0.56,-0.58 \pm 0.06$ and $-0.28 \pm 0.03 \%$ of total VFA, respectively, $\mathrm{P}<0.001$ ). Dietary supplementation of $10 \mathrm{~g} / \mathrm{kg}$ of FSG increased caproic acid concentration in animals fed with $\mathrm{C}$ diets $(+0.30 \pm 0.06$; $\mathrm{P}=0.013)$.

\section{Discussion}

As can be deduced from the results on the animals' health, the growing trial was carried out during one of the frequent outbreaks of ERE in the farm, which led to average mortality of over 35\% throughout the growing period. Under these conditions, dietary inclusion of $10 \mathrm{~g} / \mathrm{kg}$ FSG did not have any positive effect on mortality, morbidity or HRi during the experimental period, regardless of the diet in which it was included. In most of the studies carried out to date with prebiotics in rabbit's diet, no positive effects of their inclusion have been found on the health status of animals during the fattening period. Supplementation with fructooligosaccharides (Aguilar et al., 1996; Mourão et al., 2004), mannanoligosaccharides (Bovera et al., 2012) or even pre-germinated fenugreek seeds in rabbit's diet (Mabrouki et al., 2016) had no positive effects to reduce mortality associated to digestive disorders. Some authors have even observed an increase in mortality and morbidity when including galactoligosaccharides in the diet (Gidenne, 1995). Only Mourão et al. (2006) observed a reduction in the mortality of growing rabbits when they introduced mannanoligosaccharides into

the diet. In a context of ERE similar to that observed in this work, Ocasio-Vega et al. (2018 and 2019) observed that the inclusion of cellobiose in drinking water had 
(a)

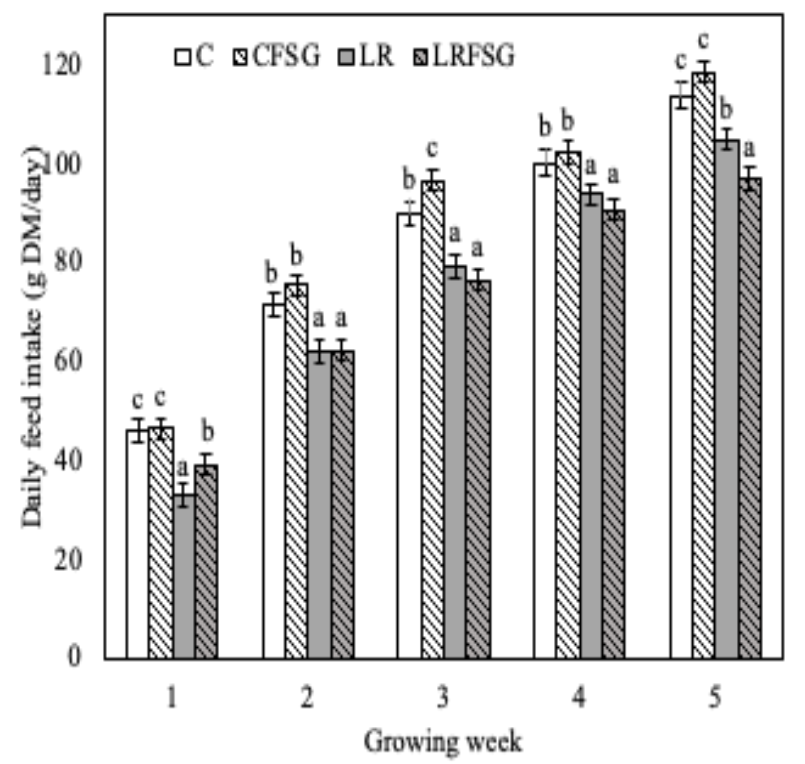

(b)

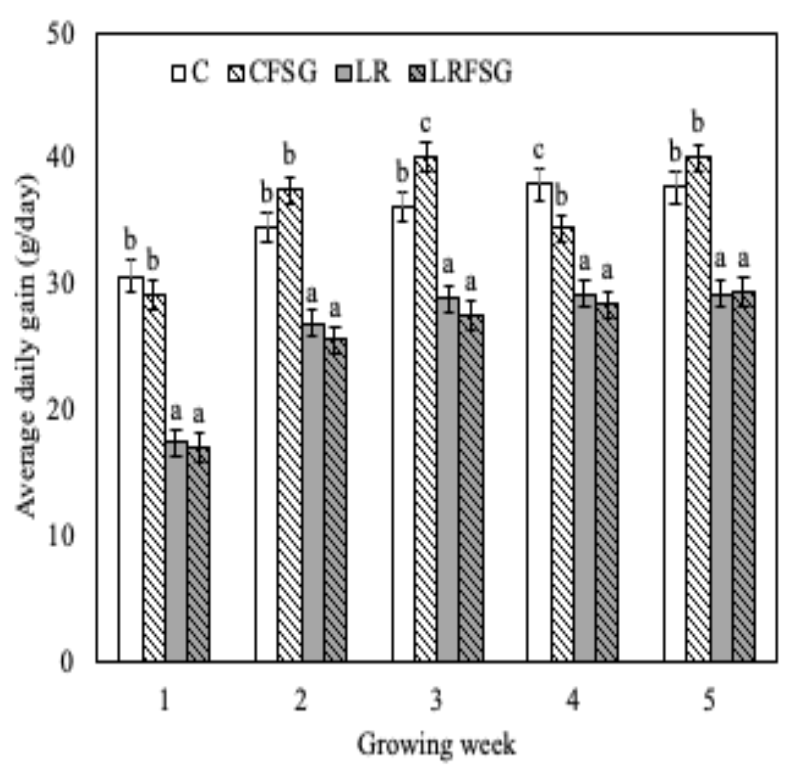

(c)

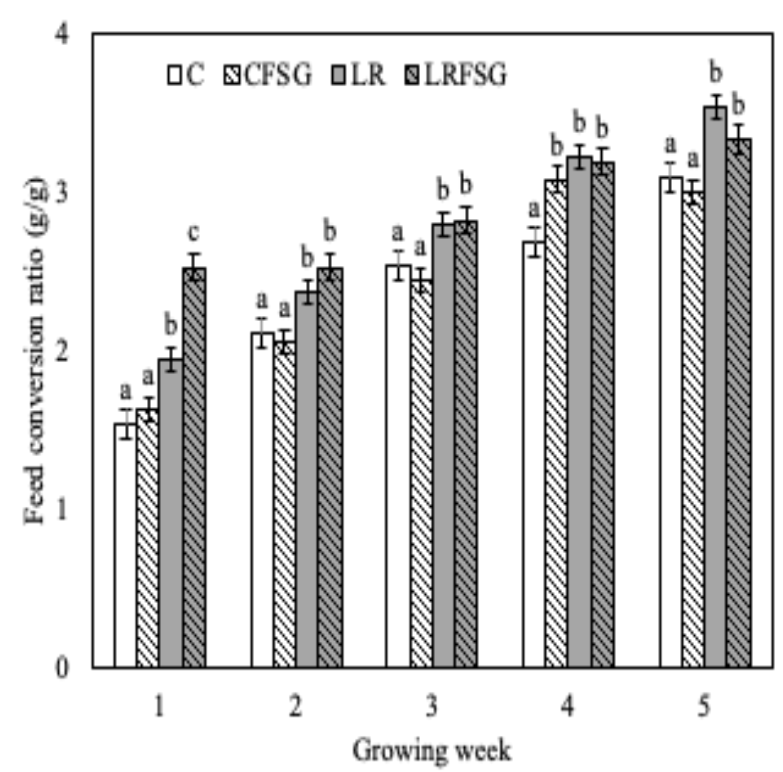

Figure 3.1. Effect of the experimental diet on the (a) daily feed intake (g DM/day), (b) average daily gain (g/d) and (c) feed conversion ratio (g/g) during the growing period. FSG, fenugreek seeds gum; C, conventional diet; CFsG, conventional diet supplemented with 1\% of FSG; LR, low risk diet; LRFSG, low risk diet supplemented with 1\% of FSG; a,b,cmeans within a growing week not sharing superscript are significant different at $\mathrm{P}<0.05$. 
no effect in high SF diets, but it seemed to reduce mortality when the content of SF was lower. In the present study, the best results were obtained with the LR diet without the inclusion of FSG. However, under an ERE outbreak that affects almost $40 \%$ of the animals, the use of FSG in a no-medicated feed did not seem to be an alternative to antibiotics.

As expected, low-risk diets with high SF and low CP levels, significantly reduced mortality and HRi respect to conventional diets in a context of ERE without antibiotics treatment (17 points of percentage in mortality). In a similar context of ERE outbreak without antibiotics, Martínez-Vallespín et al. (2011) also observed a clear reduction in mortality when increasing SF for starch or when the dietary protein was reduced ( -15 and -20 points of percentage, respectively). In fact, in this last study was confirmed the beneficial effects on growing rabbits' health obtained through increasing SF replacing starch and reducing $\mathrm{CP}$ in their diet (Carabaño et al., 2009; Gidenne, 2015).

Respect to nutrient utilization, when dietary fibre content is increased by reducing starch and protein in rabbit's diet, digestive efficiency is usually also reduced. In the present study, increasing soluble and insoluble fibre at expenses of starch and protein resulted in higher CTTAD of NDF and ADF and lower CTTAD of DM, OM and CP. Trocino et al. (2013) point up that digestibility of main fibre fractions increases linearly with the dietary SF level due to the high digestibility of all the fibre constituents from sources of SF (mainly beet pulp). On the other hand, it is well known that an increase in total dietary fibre $(+169$ $\mathrm{g} / \mathrm{kg}$ DM) decreases faecal digestibility of main nutrients because it usually increases the rate of passage of digesta.

Theoretically, prebiotic inclusion must improve digestive efficiency due to an improvement of mucose health. For example, Mourão et al. (2006) observed an increased length of ileal villi associated to dietary supplementation of MOS in rabbits. However, viscous nature of gums sometimes is responsible for reduced digestibility and nutrient absorption by reducing the contact of nutrients with the 
absorptive surface (Read, 1986), as observed with guar gum galactomannans supplementation in broiler diets (Kakani, 2013). In the present work we have not found any significant effect of FSG on the use of nutrients. With C diets, the inclusion of FSG seems to slightly improve the utilization of fibrous fractions (2 to 3 percentage points), which is not observed when the diet is rich in SF. In fact, Bovera et al. (2012) observed an increase of TTAD of ADF and cellulose when adding mannanoligosaccharides to a conventional rabbit diets, that the authors associated it to a higher cellulolytic activity of caecal microbiota. These results could show that the contribution to cellulolytic activity of prebiotics may be of interest in SF-poor diets, whereas SF-rich diets have enough fermentable sources so that the contribution of a prebiotic would be diluted.

Despite their clear benefit in reducing the risk of digestive disorders, the use of low-risk diets could lead to lower growth performance and feed efficiency of animals. Although the ADF level in LR diets did not exceed the limit considered by Gidenne (2015) as a red threshold that, once exceeded, animals could not increase their intake to meet their energetic needs ( $\mathrm{ADF}<250 \mathrm{~g} / \mathrm{Kg} \mathrm{DM})$, animals fed with LR diets showed a clearly lower growth performance. This worse growth performance $(-28 \%)$ was due to both a lower feed intake $(-20 \%)$ and a worse feed efficiency (-12\%). Under normal conditions, a feed with a higher ADF content would favour an increase in DFI (Gidenne, 2015). However, several works have observed that, when the SF content is increased by the inclusion of a high amount of beet pulp ( $270 \mathrm{~g} / \mathrm{Kg}$ in this work), sometimes a decrease in feed intake was observed during the growing period. Thus, Trocino et al. (2013) and Caîsin et al. (2020) observed a reduction of DFI (-7 and $-12 \%$, respectively) when including beet pulp (275 and $230 \mathrm{~g} / \mathrm{kg}$, respectively). This decrease in DFI could sometimes be explained by a higher content of the feed, but also by an increase in the digestive filling of the animals (both feed and water). In fact, Caîsin et al. (2020) observed a significant increase in full gastrointestinal tract and caecum, as well as higher water content in the caecum in high SF diets. Finally, the worse 
feed efficiency with LR diets could be also associated to their lower protein provision, also observed in previous works when protein level was reduced in growing rabbits (Martínez-Vallespín et al., 2011).

Growth performance was not affected by dietary inclusion of FSG independently of the type of diet. These results agree with those observed in the literature where the inclusion of different prebiotic types had not any effect on growing rabbit performance (Peeters et al., 1992; Lebas, 1996; Mourão et al., 2004; Bovera et al., 2012; Mabrouki et al., 2016).

All caecal parameters were not affected by dietary inclusion of FSG except that of caproic acid. The caproic acid content in the caecum was significantly higher in animals fed with $C$ diets and especially those with CFSG, nor being any effect of FSG addition in LS diets. Caproic acid seems to be an end product of starch fermentation (Marounek et al., 1997), and Kenearly et al. (1995) have reported that bacteria that efficiently produce low levels of ethanol and acetate from cellulose, in $\mathrm{pH}$ values near to neutrality could produce caproic acid. These results could explain the higher proportion of caproic acid in rabbits with $\mathrm{C}$ diets. Further studies have also reported in vitro antimicrobial activity of caproic acid, reducing the enteropathogenic E. coli strain counts (Skrivanová and Marounek, 2007). In fact, Ocasio-Vega et al. (2018) observed higher ileal proportions of caproic in groups with the lowest mortality rate. However, CFSG group, with higher caecal proportions of caproic acid, did not show a better health status, although it was the one that showed the highest feed intake and growth values of all the groups.

LR diets showed lower DM and N-NH3, as well as higher VFA caecal content. As mentioned above, the decrease of caecal digesta DM could be related to the highwater holding capacity of pectins from sugar beet pulp (Gidenne et al., 2010) and the reduced feed intake with LR diets. In addition, higher concentration of total

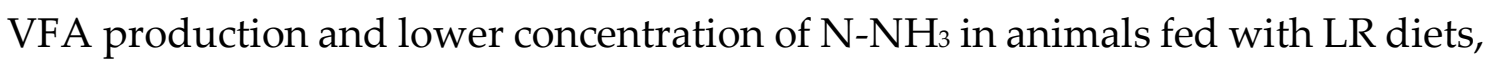
direct consequence of their chemical composition, has been frequently related 
with reduced risk of digestive disorders in growing rabbits (Gidenne et al., 2010; Chiou et al., 1994). Reduced feed intake and favourable caecal environment may be behind the lower rabbit mortality with these low-risk diets.

Respect to the VFA profile, LR diets showed higher proportions of acetic, propionic, isobutyric and isovaleric acids but lower proportions in butyric and valeric acids in the caecum. These results are in disagree with recent studies reporting that butyric acid ileal proportion is usually higher in rabbits' groups with lower mortality rate (Ocasio-Vega et al., 2018). Our results fall within the specific range of the VFA profile with a predominance of acetate (65-87 mmol 100 $\left.\mathrm{mL}^{-1}\right)$ followed by butyrate $\left(6-28 \mathrm{mmol} 100 \mathrm{~mL}^{-1}\right)$ and then propionate $(3-11 \mathrm{mmol}$ $100 \mathrm{~mL}^{-1}$ ) as described by Gidenne (1997). García et al. (2002) reported that molar proportions are influenced by dietary inclusion beet pulp, increasing acetate and propionate proportions but decreasing butyrate decreased. Finally, isobutyric and isovaleric acids are bacterial end products from degradation of valine and leucine amino acids, respectively (Van Soest, 1994), and so frequently promoted when fermentative activity increases (LR diets), while caecal valerate production is linked to amylotytic microbiota (Xiccato et al., 2002).

\section{Conclusion}

In conclusion, inclusion of $10 \mathrm{~g} / \mathrm{kg}$ of FSG as a prebiotic in growing rabbit diets was not enough to reduce the risk of digestive disorder in growing rabbits during a ERE outbreak. Dietary inclusion of FSG also had no relevant effect on nutrients utilisation, growth performance and caecal environment. Diets with high soluble fibre and low protein levels were once again a useful tool to reduce the incidence of ERE on rabbits, although with negative consequences on their growth performance.

\section{Acknowledgements}

This study is supported by the Interministerial Commission for Science and Technology (CICYT) of the Spanish Government (AGL2017-85162-C2-1R), the 
Universitat Politècnica de València (Project 20180290; Spain), and the Higher School of Agriculture of Mateur of the Carthage University (Tunisia Republic). Grant for Jihed Zemzmi from the Carthage University is also gratefully acknowledged.

\section{References}

Aguilar J. C, Roca T, Sanz E. 1996. Fructo-oligosaccharides in rabbit diet. Study of efficiency in suckling and fattening periods. In: Proceedings of the $6^{\text {th }}$ World Rabbit Congress, Toulouse, France, 7377.

AOAC 2002. Official methods of analysis of the AOAC International, 17th ed. AOAC International, Gaithersburg, MD (USA).

Badiola I, Pérez de Rozas A, González J, Aloy N, García J, Carabaño R. 2016. Recent advances in ERE in growing rabbits. In, Qin Y, F. Li, T. Gidenne, editors. In: Proceedings of the $11^{\text {th }}$ World Rabbit Congress. June 15 to 18, Qingdao, China.

Batey IL 1982. Starch Analysis Using Thermostable Alpha-Amylases. Starch/Stärke. 34, 125-128.

Bäuerl C, Collado MC, Zúñiga M, Blas E, and Pérez Martínez G 2014. Changes in cecal microbiota and mucosal gene expression revealed new aspects of epizootic rabbit enteropathy. Plos One. 9, e105707.

Bovera F, Marono S, Di Meo C, Piccolo G, Lannaccone F and Nizza A. 2010. Effect of mannanoligosaccharides supplementation on caecal microbial activity rabbits. Animal. 4, 1522-1527.

Bovera F, Lestingi A, Marono S, Iannaccone F, Nizza S, Mallardo K, Martino L, Tateo A. 2012. Effect of dietary mannan-oligosaccharides on in vivo performance, nutrient digestibility and caecal content characteristics of growing rabbits. Journal of Animal Physiology and Animal Nutrition, 96, 130-136.

Caîsin L, Martínez-Paredes E, Ródenas L, Moya V. J, Pascual J. J, Cervera C, Blas E, Pascual M. 2020. Effect of increasing lignin in isoenergetic diets at two soluble fibre levels on digestion, performance and carcass quality of growing rabbits. Animal Feed Science and Technology, 114396.

Carabaño R, Villamide M. J, García J, Nicodemus N, Llorente A, Chamorro S, Menoyo D, García-Rebollar P, García-Ruiz A.I, de Blas J. C. 2009. New concepts and objectives for protein-amino acid nutrition in rabbits, A review. World Rabbit Science, 17, 1-14. 
Chiou P. W, Bi Y, Chang L. 1994. Effect of different components of dietary fiber on the intestinal morphology of domestic rabbits. Comparative Biochemistry and Physiology Part A, Physiology, 108, 629-638.

de Blas C, Mateos C. C. 2010. Feed Formulation. In: Nutrition of the rabbit, de Blas, C, Wiseman, J, Eds.; CABI Publishing, Wallingford, UK, 2010, pp. 222-232.

Dewree R, Licois D, Coudert P, Lassence C, Vindevogel H, Marlier D. 2003. L'enteropathie epizootique du lapin (EEL), etude du role des infections par Clostridium perfringens dans l'etio-pathogenie de ce syndrome. In: Proceedings of the $10^{\text {ème }}$ Journées de la Recherche Cunicole, ITAVI Ed, Paris, France, pp. 251-254.

Fernández-Carmona J, Blas E, Pascual J. J, Maertens L, Gidenne T, Xiccato G, García J. 2005. Recommendations and guidelines for applied nutrition experiments in rabbits. World Rabbit Science, 13, 209-228.

García J, Nicodemus N, Carabaño R, de Blas C. 2002. Effect of inclusion of defatted grape seed meal in the diet on digestion and performance of growing rabbits. Journal of Animal Science, 80, 162-170.

Gidenne T .1995. Effect of fibre level reduction and glucooligosaccharide addition on the growth performance and caecal fermentation in the growing rabbit. Animal Feed Science and Technology. 56, 253-263.

Gidenne T .1997. Caeco-colic digestion in the growing rabbit, impact of nutritional factors and related disturbances. Livestock Production Science, 51, 73-88.

Gidenne $\mathrm{T}$.2015. Dietary fibres in the nutrition of the growing rabbit and recommendations to preserve digestive health, a review. Animal. 9, 227-242.

Gidenne T, Garcia J, Lebas F, Licois D. 2010. Nutrition and feeding strategy, interactions with pathology. In: de Blas C, Wiseman J. (Eds.), Nutrition of the Rabbit, $2^{\text {nd }}$ ed. CAB International, Wallingford (UK). 179-199.

Gidenne T, Kerdiles V, Jehl N, Arveux P, Eckenfelder B, Briens C, Stephan S, Fortune H, Montessuy S, Muraz G. 2013. Protein replacement by digestible fibre in the diet of growing rabbits, 2.Impact on performances, digestive health and nitrogen output. Animal Feed Science and Technology 183, 142-150.

Huybens N, Houeix J, Licois D, Mainil J, Marlier D. 2009. Inoculation and bacterial analyses of fractions obtained from the reference inoculum TEC4 which experimentally reproduces epizootic rabbit enteropathy. World Rabbit Science, 17, 185-193. 
Jouany J. P. 1982. Volatile fatty acid and alcohol determination in digestive contents, silage juices, bacterial cultures and anaerobic fermentor contents. Sciences des Aliments. 2, 131-144.

Kakani, R. 2013. Prebiotic properties of yeast cell wall mannanoligosaccharides and guar gum galactomannans in starting broilers (Doctoral dissertation).

Kenealy W. R, Cao Y, Weimer P. J. 1995. Production of caproic acid by cocultures of ruminal cellulolytic bacteria and Clostridium kluyveri grown on cellulose and ethanol. Applied Microbiology and Biotechnology, 44, 507-513.

Licois D, Coudert P, Marlier D. 2006. Epizootic rabbit enteropathy. In: Maertens, L. and Coudert $P$, editors. Recent advances in rabbit science. Melle, Belgium, Institute for Agricultural and Fisheries Research (ILVO), 163-170.

Mabrouki S, Chalghoumi R, Abdouli H. 2017. Effects of pre-germinated fenugreek seeds inclusion in low-fiber diets on post-weaned rabbits' health status, growth performances, carcass characteristics, and meat chemical composition. Tropical animal health and production, 49, 459-465.

Marlier D, Dewrée R, Lassence C, Licois D, Mainil J, Coudert P, Meulemans L, Ducatelle R, Vindevogel H. 2006. Infectious agents associated with epizootic rabbit enteropathy, isolation and attempts to reproduce the syndrome. The Veterinary Journal, 172, 493-500.

Marounek M, Vovk S. J, Benda V. 1997. Fermentation patterns in rabbit caecal cultures supplied with plant polysaccharides and lactate. Acta Veterinaria Brno, 67, 9-13.

Martínez-Vallespín B, Martínez-Paredes E, Ródenas L, Cervera C, Pascual J. J, Blas E. 2011. Combined feeding of rabbit female and young, Partial replacement of starch with acid detergent fibre or/and neutral detergent soluble fibre at two protein levels. Livestock Science, 141(2-3), 155-165.

Mertens D. R. 2002. Gravimetric determination of amylase-treated neutral detergent fibre in feeds with refluxing in beakers or crucibles, Collaborative study J. AOAC Int. 85, 1217-1240.

Mourão J. L, Alves A, Pinheiro V. 2004. Effects of fructooligosaccharides on performances of growing rabbits. In: Proceedings of the $8^{\text {th }}$ World Rabbit Congress, Puebla, México, 915-921.

Mourão J. L, Pinheiro V, Alves A, Guedes C. M, Pinto L, Saavedra M.J, Spring P, Kocher A. 2006. Effect of mannan oligosaccharides on the performance, intestinal morphology and cecal fermentation of fattening rabbits. Animal Feed Science and Technology, 126, 107120 .

Mudgil D, Barak S, Patel A, Shah N. 2018. Partially hydrolyzed guar gum as a potential prebiotic source. International Journal of Biological Macromolecules, 112, 207-210. 
Ocasio-Vega C, Delgado R, Abad-Guamán R, Carabaño R, Carro M.D, Menoyo D, García J. 2018. The effect of cellobiose on the health status of growing rabbits depends on the dietary level of soluble fibre. Journal of Animal Science, 96, 1806-1817.

Ocasio-Vega C, Delgado R, Abad-Guamána R, Carabaño R, Carroa MD, García J. 2019. Effect of cellobiose supplementation on growth performance and health in rabbits. Livestock Science, 221, 163-171.

Peeters J. E, Maertens L, Orsenigo R, Colin M. 1995. Influence of dietary beet pulp on caecal VFA, experimental colibacillosis and iota-enterotoxaemia in rabbits. Animal Feed Science and Technology, 51, 123-139.

Perez J. M, Gidenne T, Bouvarel I, Arveux P, Bourdillon A, Briens C, Le Naour J, Messager B and Mirabito L .2000. Replacement of digestible fibre by starch in the diet of the growing rabbit. II. Effects on performances and mortality by diarrhea. Annales de Zootechnie 49, 369-377.

Read, N. W. 1986. Dietary fiber and bowel transit. In: Dietary Fiber (pp. 81-100). Springer, Boston, MA.

Robertson J. B and Van Soest P. J. 1981. The detergent system analysis and its application to human foods in the analysis of dietary fibre food, ED. Theander J, Dekker INC, 123-157.

Salavati Schmitz S and Allenspach K. 2017. Effects of different oligosaccharides on growth of selected probiotic bacterial strains. Journal of Microbial and Biochemical Technology, 9, 572-576.

Statistical Analysis Software (SAS) 2009. SAS/STAT User's Guide (Release 9.2). SAS Institute. Inc, Cary NC, USA.

Skrivanová E, and Marounek M. 2007. Influence of pH on antimicrobial activity of organic acids against rabbit enteropathogenic strain of Escherichia coli. Folia Microbiologica. 52, 70-72.

Szalo I. M, Lassence C, Licois D, Coudert P, Poulipoulis A, Vindevogel H, Marlier D. 2007. Fractionation of the reference inoculum of epizootic rabbit enteropathy in discontinuous sucrose gradient identifies aetiological agents in high density fractions. The Veterinary Journal, 173(3), 652-657.

Tazzoli M, Carraro L, Trocino A, Majolini D and Xiccato G. 2009. Replacing starch with digestible fibre in growing rabbit feeding. Italian Journal of Animal Science, 8 (suppl. 3), 148-250.

Trocino A, García J, Carabaño R, Xiccato G. 2013. A meta-analysis on the role of soluble fibre in diets for growing rabbits. World Rabbit Science, 21, 1. 
Trocino A, Fragkiadakis M, Majolini D, Carabaño R and Xiccato G. 2011. Effect of the increase of dietary starch and soluble fibre on digestive efficiency and growth performance of meat rabbits. Animal Feed Science and Technology, 165, 265-277.

Van Soest PJ 1994. Nutritional Ecology of the Ruminant, $2^{\text {nd }}$ edn. Comstock Publishing Associates, Ithaca, NY. 354-370.

Van Soest PJ, Robertson JB, and Lewis BA 1991. Methods for dietary fibre, neutral detergent fibre, and non-starch polysaccharides in relation to animal nutrition. Journal of Dairy Science. 74, 3583-3597.

Xiccato G, Trocino A, Sartori A, Queaque P. I. 2002. Effect of dietary starch level and source on per-formance, caecal fermentation and meat quality in growing rabbits. World Rabbit Science 10, 147-157.

Xiccato G, Trocino A, Majolini D, Fragkiadakis M and Tazzoli M 2011. Effect of decreasing dietary protein level and replacing starch withs oluble fibre on digestive physiology and performance of growing rabbits. Animal 5, 1179-1187.

Zemzmi J, Mabrouki S, Abdouli H, Najar T. 2017. Preliminary characterization of fenugreek seed gum for use as prebiotic in rabbits' nutrition. In: Proceedings of the $20^{\text {th }}$ International Symposium on housing and diseases of rabbits, fur providing animals and pet animals, 17-18 May. Celle, Germany. 179-186.

Zemzmi J, Ródenas L, Blas E, Najar T, Pascual J. J. 2020b. Characterisation and in Vitro evaluation of fenugreek (Trigonella foenum-graecum) seed gum as a potential prebiotic in growing rabbit nutrition. Animals, 10(6), 1041.

Zemzmi J, Ródenas L, Blas E, Abdouli H, Najar T, Pascual J. J. 2020a. Preliminary evaluation of fenugreek (Trigonella foenum-graecum) seed gum as a potential prebiotic for growing rabbits in Tunisia, effects on in vivo faecal digestibility and in vitro fermentation. World Rabbit Science. 28 (3). 


\section{General discussion}


In the laboratory of nutrition of the High School of Agriculture of Mateur, fenugreek (Trigonella foenum-graecum), as a local crop largely cultivated in Tunisia, has been the subject of many studies, evaluating its inclusion on the carotenoids, cholesterol and triglyceride level of egg yolk in laying hens (Omri et al., 2017 and 2019), and on growth performance and meat quality in growing rabbits when included in low fibre diet conditions (Mabrouki et al., 2017). Besides, its inhibitor effect against Escherichia coli isolated from rabbits has been also studied (Chalghoumi et al., 2016). All results were satisfying but the strong odour residues of fenugreek seeds in eggs and meat limit its utilization even in small quantities in livestock nutrition.

However, fenugreek seeds endosperm is rich in a polysaccharide recognized as galactomannan, with a structural component of a main chain of mannose with branches of galactose. Galactomannan from fenugreek seeds is a water-soluble compound precipitated with ethanol 95º, which eliminate the odour unpleasant effect. This extract has been reported as a potential prebiotic, which play an important role in modulating gut flora by acting as a substrate to beneficial microbes such as Bacillus coagulans (Majeed et al., 2018). Fenugreek seed gum (FSG) has been tested on laying hens (Yasothai, 2013) and broilers, exhibiting a prebiotic effect on both cases (Zhang, 2005), but it has never been tested in rabbits. FSG was initially extracted (Zemzmi et al., 2017), and its fermentability by rabbit caecal bacteria and the repeatability of the extraction was confirmed. The effect of its gradual inclusion in the diet (at 0, 1.25, 2.5, 5 and $1000 \mathrm{~g} / \mathrm{kg}$ ) on the fermentation activity of the rabbit caecal bacteria was in vitro evaluated and then a first in vivo trial was carried out by incorporating $0,2.5$ and $5 \mathrm{~g} / \mathrm{kg}$ of FSG in a commercial rabbit diet at the farm of the Higher School of Agriculture of Mateur (Tunisia). In this first trial, FSG showed a high fermentable potential by the caecal microbiota, increasing in vitro VFA concentration, decreasing caecal $\mathrm{pH}$, and slightly increasing both NDF and ADF apparent faecal digestibility coefficients 
(but no significantly). In any case, although prebiotics could influence a few nutrient digestibility, it main goal is addressed to modulate caecal microbiota activity for better digestive health.

The in vivo inclusion up to $5 \mathrm{~g} / \mathrm{kg}$ of FSG, in a commercial diet for growing rabbit under Tunisian conditions, was not enough to show relevant effects on in vivo caecal VFA concentration and profile. Moreover, sanitary conditions of the experimental farm were adequate, and no digestive problems were noticed during the trial.

However, pure FSG increased the extent of gas production (expressed as the asymptotic gas production) and decreased the time after incubation at which half of the asymptotic amount of gas has been formed, which indicate that FSG could be a good substrate to boost caecal microbiota activity. This hypothesis has been supported by other results such as: decreasing caecal $\mathrm{pH}$, lactic acid and $\mathrm{N}-\mathrm{NH}_{3}$ concentration while increased caecal VFA concentration. However, it was difficult to observe relevant differences when included at low doses. In addition, direct in vitro fermentation of FSG is a direct and incomplete digestion which does not correspond to what actually happens in the rabbit's digestive tract. Thereby measures such as pre-digestion by gastro-intestinal enzymes must be considered.

Therefore, in the second experiment, pure FSG and gradual levels of FSG $(0,5$, 10,15 and $20 \mathrm{~g} / \mathrm{kg}$ ) were included in an SF-rich diet (sugar beet pulp) and a ligninrich diet (grape seeds) considering pre-digestion with pepsin and pancreatin enzymes. This study revealed that FSG resist to pre-digestion before the caecum where only $145 \mathrm{~g} / \mathrm{kg}$ were degraded, which confirm one of the principal conditions of its prebiotic potential. Moreover, almost all the fraction not degraded during the pre-digestion was used in the fermentation by caecal microbiota, confirming the results of the first experiment. Therefore, FSG seems to satisfy the conditions required to a feed ingredient to be considered prebiotic, 
according to Roberfroid (2007), such as resistant to enzymatic digestion before the caecum and the high fermentation once reach the caecum. According to the third condition which is selective stimulating of growth and activity of some microbiota species, pure FSG had a different VFA profile to that obtained with SF and IF diets, but gradual dietary inclusion of FSG only modified a little this profile.

For better understanding of FSG behaviour on in vivo conditions, $10 \mathrm{~g} / \mathrm{kg}$ of FSG was included in two types of diets: conventional rabbit diet (C) and low risk (LR) diet rich in SF and low in protein. The objective was to investigate if the composition of the feed could affect the effect of the prebiotic in animals. Under these conditions, we did not observe any relevant effect of FSG neither on health status nor on nutrient digestibility and growth performance. However, the use of LR diets was shown as a good nutritional strategy to improve the sanitary state, at the cost of animal's growth loss.

In both digestibility trials, when FSG supplemented to the commercial feed up to 5 or $10 \mathrm{~g} / \mathrm{kg}$, apparent faecal digestibility of main fibre fractions seems to be slightly improved in conventional diets (2 to 3 percentage points). Those results suggest that FSG could promote fibrolytic bacteria in the rabbits' caecum. Accordingly, Gómez-Conde et al. (2007) and (2009) reported that increasing dietary SF content may stimulate the growth of fibrolytic microbiota in the gut, thus increasing the utilisation at both ileum and caecum of insoluble fibre fractions (hemicelluloses and ADF). However, other feed ingredients such as MOS reduced cellulose digestibility when added in rabbits and pigs' diet, explained by a lower cellulotic activity observed in the caecum of those animals (Lipinski et al., 2005; Volek et al., 2007). However, all the fibre fractions were decreased by the gradual inclusion of FSG from 0 to $20 \mathrm{~g} / \mathrm{kg}$ in the SF diet already even in the in vitro enzymatic pre-digestion, $(-1.6,-1.1,-0.92 \mathrm{~g} / \mathrm{kg}$ for NDF, ADF and cellulose respectively for each $\mathrm{g} / \mathrm{kg}$ of FSG added). These results seem to 
indicate that the inclusion of FSG would increase the utilization of the fibrous fractions.

Pure FSG in vitro fermentation increased the proportions of propionate, isobutyrate and isovalerate while decreased that of caproate in comparison to the profile for a rabbit diet. In the case of propionate and caproate similar results were found by Marounek et al. (1997), where inulin fermentation increased the proportion of propionate and that of starch increased the proportion of caproate. In contrary, $10 \mathrm{~g} / \mathrm{kg}$ FSG inclusion in a conventional diet increased the proportion of caproate in the caecum $(\mathrm{P}=0.013)$. This could be useful as a lower mortality rate was associated to rabbits' group with a high ileal proportion of caproate (OcasioVega et al., 2018). Caproate also showed antimicrobial activity by reducing in vitro the concentration of viable cells of an enteropathogenic E. coli strain in high and low pH values (Skrivanová and Marounek, 2007). On the other hand, the higher proportions of iso-butyrate and isovalerate, end products of valine and leucine amino acids fermentation (Van Soest, 1994), observed in the caecum of rabbit feed with FSG could be related to the no negligible amount of the amino acids in the gums, which would survive enzymatic pre-digestion but would be available to the caecal microbiota. This circumstance could be dangerous, since it is not recommended to increase the flow of ileal $\mathrm{N}$ to the cecum, but our results indicate that the inclusion of FSG even reduced ammonia $\mathrm{N}$ in the cecum.

However, according to our results, dietary inclusion of FSG did not influence mortality and morbidity. Main of the previous studies have also observed the lack of effect of prebiotics on the health status of animals, the ultimate goal of their use. Only a few have seen improvements. For example, Volek et al. (2007), when tested dietary inclusion of $3 \mathrm{~g} / \mathrm{kg}$ of MOS, did not found any effect on the sanitary status of growing rabbits, but the inclusion of $4 \mathrm{~g} / \mathrm{kg}$ of inulin was related to a reduced morbidity and the health risk index. Other disaccharide, such as cellobiose, decreased mortality when supplemented in drinking water at $7 \%$ of 
rabbits group receiving low soluble fibre diet (Ocasio-Vega et al., 2019), but the same ingredient tended to increase mortality when the doses of supplementation was increased and also when given to rabbits receiving high soluble fibre diet (Ocasio-Vega et al., 2019). It was explained as a possible negative interaction between cellobiose and the specific microbiota profile developed by high soluble fibre fed rabbits. These results show that, although it seems clear that most prebiotics can affect the use of nutrients and modulate the microbiota of the caecum, in most cases these changes are not capable of producing a significant improvement in health status, that can even get worse. This different behaviour may be due to the complexity of the rabbit microbiota, and to differences in the farm environment, the digestive disorders present in the animals, and the type and dose of prebiotic used.

Regarding the use of low risk diets, animals feed with LR diets showed lower FI, growth and apparent faecal digestibility of $\mathrm{CP}$ and $\mathrm{OM}$, but higher digestibility of insoluble fibre fractions NDF and ADF. Furthermore, these diets reduced mortality, morbidity rate and the HRi. Growth performances were impaired due to the high ADF (Gidenne, 2015) and mainly to the reduced protein content of these diets. Decreasing CP from 160 to $140 \mathrm{~g} / \mathrm{kg}$ does not impair growth performance (García-Palomares et al., 2006a), but probably in our case we exceeded this limit $(121 \mathrm{~g} / \mathrm{kg})$ which impaired growth performances and final life weight of animals. Therefore, we must define the levels of protein and the main limiting amino acids that allow a good growth performance of animals without increasing the risk of digestive disorders. Other possibility could be a differentiated feeding during the fattening period, with a low protein high soluble fibre diet during the three first weeks after weaning where the digestive disorder are more frequent, and a second feeding program higher in $\mathrm{CP}$ which would permit a better coverage of the growth and a better final life weight, 
besides to a lower nitrogen excretion during all the fattening period (Maertens et al., 1997; Trocino et al., 2000).

As our experiment was conducted during an ERE outbreak, low-risk diets decreased mortality to $-18.3 \%$ compared to the conventional diets. These results confirm the interest of their use under these circumstances, at the cost of a reduction of the feeding efficiency. In fact, modifying feed composition is being one of the main tools to reduce digestive disorders, while developing and evaluating new alternatives to the use of antibiotic in growing rabbits.

\section{References}

Chalghoumi R, Mabrouki S, Abdouli H and Line J. 2016. In vitro evaluation of the antibacterial activity of fenugreek seed (Trigonella foenum-graecum) crude extracts against a rabbit Escherichia coli isolate. Pharmaceutical Biology, 4,139-144.

García-Palomares J, Carabaño R, García-Rebollar P, de Blas C, Corujo A, García Ruíz A. I. 2006. Effects of a dietary protein reduction and enzyme supplementation on growth performance in the fattening period. World Rabbit Science 14, 231-236.

Gidenne T. 2015. Dietary fibres in the nutrition of the growing rabbit and recommendations to preserve digestive health, a review. Animal, 9, 227-242.

Gómez-Conde MS, De Rozas A. P, Badiola I, Pérez-Alba L, de Blas C, Carabaño R and García J. 2009. Effect of neutral detergent soluble fibre on digestion. Livestock Science, 125, 192-198

Gómez-Conde M. S, García J, Chamorro S, Eiras P, Rebollar P. G, De Rozas A. P, Badiola I, de Blas C and Carabaño R. 2007. Neutral detergent-soluble fibre improves gut barrier function in twenty-five-day-old weaned rabbits. Journal of Animal Science, 85, 3313-3321.

Lipiński K, Purwin C, Tywończuk J, Zduńczyk Z, Wróblewska M, ŁaniewskaTrokenheim $€$ and Warmińska-Radyko I. 2005. Effects of feed additives on nutrient digestibility and bacterial status of feaces in pigs. J. Anim. Feed Science, 14, 369-372.

Mabrouki S, Chalghoumi R and Abdouli H. 2017. Effects of pre-germinated fenugreek seeds inclusion in low-fiber diets on post-weaned rabbits' health status, growth performances, carcass characteristics, and meat chemical composition. Tropical animal health and production, 49, 459-465. 
Maertens L, Luzi F, De Groote G. 1997. Effect of dietary protein and amino acids on the performance, carcass composition and N-excretion of growing rabbits. Annales de Zootechnie, 46, 255-268.

Majeed M, Majeed S, Nagabhushanam K, Arumugam S, Natarajan S, Beede K, Ali F. 2018. Galactomannan from Trigonella foenum-graecum L. seed, Prebiotic application and its fermentation by the probiotic Bacillus coagulans strain MTCC 5856. Food science \& nutrition, 6, 666-673.

Marounek M, Vovk S. J, Benda V. 1997. Fermentation patterns in rabbit caecal cultures supplied with plant polysaccharides and lactate. Acta Veterinaria Brno, 67, 9-13.

Ocasio-Vega C, Delgado R, Abad-Guamán R, Carabaño R, Carro M. D, García J. 2019. Effect of cellobiose supplementation on growth performance and health in rabbits. Livestock Science, 221, 163-171.

Ocasio-Vega C, Delgado R, Abad-Guamán R, Carabaño R, Carro M. D, Menoyo D, García J. 2018. The effect of cellobiose on the health status of growing rabbits depends on the dietary level of soluble fibre. Journal of Animal Science, 96, 1806-1817.

Omri B, Chalghoumi R, Abdouli H. 2017. Effect of dietary addition of unprocessed, autoclaved, or pre-germinated fenugreek seeds on laying hens' performance and egg quality. Revista Colombiana de Ciencias Pecuarias, 30, 147-158.

Omri B, Larbi Manel B, Jihed Z, Durazzo A, Lucarini M, Romano R, Abdouli, H. 2019. Effect of a Combination of Fenugreek Seeds, Linseeds, Garlic and Copper Sulfate on Laying Hens Performances, Egg Physical and Chemical Qualities. Foods, 8, 311.

Roberfroid M.B. 2007. Prebiotics, The Concept Revisited. J. Nutr, 137, 830-837.

Skrivanová E, Marounek M. 2007. Influence of $\mathrm{pH}$ on antimicrobial activity of organic acids against rabbit enteropathogenic strain of Escherichia coli. Folia Microbiologica. 52, $70-72$.

Trocino A, Xiccato G, Sartori A, Queaque P. I. 2000. Feeding plans at different protein levels, effects on growth performance, meat quality and nitrogen excretion in rabbits. World Rabbit Science, 8, 467-474.

Van Soest P. J. 1994. Mathematical applications, Digestibility. In Nutritional Ecology of the Ruminant, 2nd ed, Comstock Publishing Associates, Ithaca, NY, USA, 1994, pp. 354370.

Volek Z, Marounek M, Skřivanová V. 2007. Effect of a starter diet supplementation with mannan-oligosaccharide or inulin on health status, caecal metabolism, digestibility of nutrients and growth of early weaned rabbits. Animal, 1, 523-530. 
Yasothai R. 2013. Supplementation of Galactomannan Depleted Fenugreek Residue (GDFR) as Feed Additives for Broiler Breeder Hens and Commercial Broilers. Doctoral dissertation, Tamil Nadu Veterinary and Animal Sciences University, India.

Zemzmi J, Mabrouki S, Abdouli H, Najar T. 2017. Preliminary characterization of fenugreek seed gum for use as prebiotic in rabbits' nutrition. In: Proceedings of the 20th International Symposium on Housing and Diseases of Rabbits, Fur Providing Animals and Pet Animals, 17-18 May 2017, Celle, Germany, pp. 179-186.

Zhang C. 2005. Evaluation of guar meal as a source of prebiotic galactomannans for laying hens. Doctoral dissertation, Texas A\&M University. 


\section{General conclusions}


In the present work, we have tried to evaluate the potential of an extract of FSG, rich in galactomannan, as a functional product with prebiotic activity for growing rabbits.

In this way, FSG satisfies two essential conditions of the prebiotic effect, it showed resistance to in vitro enzymatic digestion and was totally fermented in vitro by caecal bacteria.

Consequently, in both trials tested in the present thesis, pure FSG promoted the in vitro caecal fermentation as expected for a prebiotic, reducing caecal $\mathrm{pH}$ and $\mathrm{N}-\mathrm{NH}_{3}$ content, increasing total VFA production and modulating VFA profile. However, although FSG linear inclusion up to $20 \mathrm{~g} / \mathrm{kg}$ in growing rabbits feed led to a slight reduction in the solubility of some nutrients during the in vitro enzymatic digestion, and FSG increased the fermentation fraction of the diets (linearly increasing the total VFA level and decreasing the caecal $\mathrm{pH}$ ), no relevant changes on the in vitro fermentation profile of the diet were observed.

Dietary inclusion of FSG up to $10 \mathrm{~g} / \mathrm{kg}$ did not affected in vivo apparent digestibility coefficients of main nutrients, although slightly increased the digestibility coefficients of some fibre fractions.

Dietary inclusion of $10 \mathrm{~g} / \mathrm{kg}$ of FSG as a prebiotic in growing rabbit diets was not enough to reduce the risk of digestive disorder in growing rabbits during a ERE outbreak and had no relevant effect on growth performance and in vivo caecal environment.

On the contrary, diets with high soluble fibre and low protein levels were once again a useful tool to reduce the incidence of ERE on rabbits, although with negative consequences on their growth performance. 
Perspectives 
The perspectives of this thesis are,

For a better understanding of the potential effect of FSG on the digestive physiology of young rabbits after weaning, results on the effect of its inclusion on intestinal histomorphology and caecal microbiota must be provided in the future.

Digestibility and absorption at distal ileum level will provide more information on its behaviour as a prebiotic.

Purification of the extract eliminating its protein content and using higher levels of inclusion in the diet must be tested.

Finally, some ingredients of the rabbit's diet contain non-negligible amounts of galactomannan, maybe selecting feedstuffs with no galactomannan content will help us to better understand galactomannan effect on the digestive physiology of the rabbit. 


\section{Dissemination of Results and Predoctoral Stay}




\section{Publications}

Zemzmi J, Ródenas L, Blas E, Abdouli H, Najar T, Pascual J. J. 2020. Preliminary evaluation of fenugreek (Trigonella foenum-graecum) seed gum as a potential prebiotic for growing rabbits in Tunisia, effects on in vivo faecal digestibility and in vitro fermentation. World Rabbit Science. In press.

Zemzmi J, Ródenas L, Blas E, Najar T, Pascual J. J. 2020. Characterisation and in vitro evaluation of fenugreek (Trigonella foenum-graecum) seed gum as a potential prebiotic in growing rabbit nutrition. Animals, 10(6), 1041.

Zemzmi J, Ródenas L, Blas E, Najar T, Pascual J. J. aaaa. Effect of fenugreek seed gum dietary supply in conventional rabbit diet and low digestive risk diet on in vivo performance, nutrient digestibility and caecal environment of growing rabbits. In revision.

\section{International Congress}

Zemzmi J, Ródenas L, Blas E, Martínez-Paredes E, López-Lujan M. C, Najar T, Pascual J. J. 2019. Galactomannan fenugreek extract as proposed alternative to antibiotics in young rabbit's nutrition: Abstract and Oral presentation. In: Proceedings of the 70 th Annual Meeting of the European Federation of Animal Science, Ghent, Belgium.

Zemzmi J, Ródenas L, Blas E, Martínez-Paredes E, López-Lujan M. C, Najar T, Pascual J. J. 2019. Efecto de la inclusión de un galactomanano en piensos con diferente fibra soluble sobre la digestibilidad y la actividad cecal en conejos de engorde. In: Proceedings of the 44 Symposium de Cunicultura de ASESCU, 5-6 de Junio 2019, Aranda de Duero, Spain.

Zemzmi J, Ródenas L, Blas E, Martínez-Paredes E, López-Lujan M. C, Moya J, Najar T, Pascual J. J. 2019. Caracterisation et évaluation du potentiel prebiotique apporté par le galactomannan extrait du fenugrec chez le lapin en croissance. In: Proceedings of le 18 ème Journées de la Recherche Cunicole, 17-18 Mai 2019, Nantes, France.

Zemzmi J, Rodenas L, Blas E, Abdouli H, Najar T, Pascual J. J. 2018. Efecto de la inclusión de galactomananos en el pienso sobre la digestibilidad de los nutrientes en conejos en crecimiento. In: Proceedings of 43 Symposium de Cunicultura de ASESCU, 30-31 de Mayo 2018, Calamocha, Spain. 
Zemzmi J, Mabrouki S, Abdouli H, Najar T. 2017. Preliminary characterization of fenugreek seeds gum for use as prebiotic in rabbits' nutrition. In: Proceedings of the $20^{\text {th }}$ International Symposium on housing and diseases of rabbits, fur providing animals and pet animals, 17-18 May 2017, Celle, Germany, 179-186.

\section{Predoctoral Stay}

Project Title: Study of the effect of probiotic supplementation on the establishment of the digestive microbiota and the immune status of dairy calves during the pre-weaning period.

Hosting Institutions: Engineering School of Purpan \& UMR 1388 INRA-INPT GenPhySE.

Supervisor: Asma Zened (asma.zened@purpan.fr)

Duration: a full time 6 months stay from February to July of 2019. 